\title{
Iridium(III)-Catalyzed Intermolecular Allylic C-H Amidation of Internal Alkenes with Sulfonamides
}

\author{
Pinki Sihag and Masilamani Jeganmohan* \\ Department of Chemistry, Indian Institute of Technology, Madras-600036, India \\ E-Mail: mjeganmohan@iitm.ac.in
}

Supporting Information (SI)

Table of Contents

S2

Spectra related to mechanistic studies

S3-S67

Copies of NMR spectra 


\section{Spectra related to mechanistic studies:}

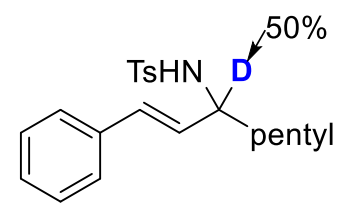

[D]-3qa

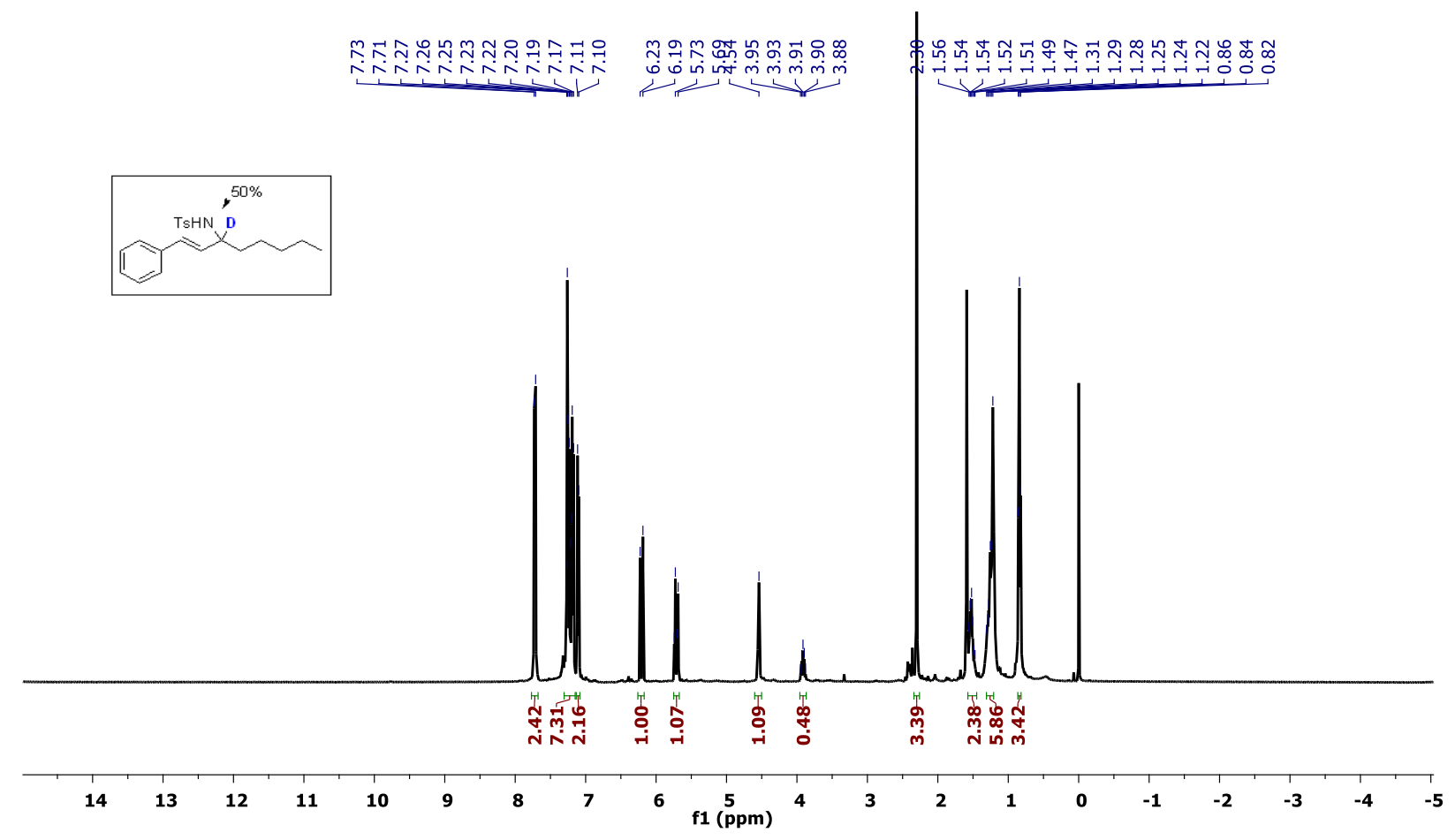




\section{Copies of NMR spectra}

${ }^{1} \mathrm{H}$ and ${ }^{13} \mathrm{C}$ spectra of compound 3aa:
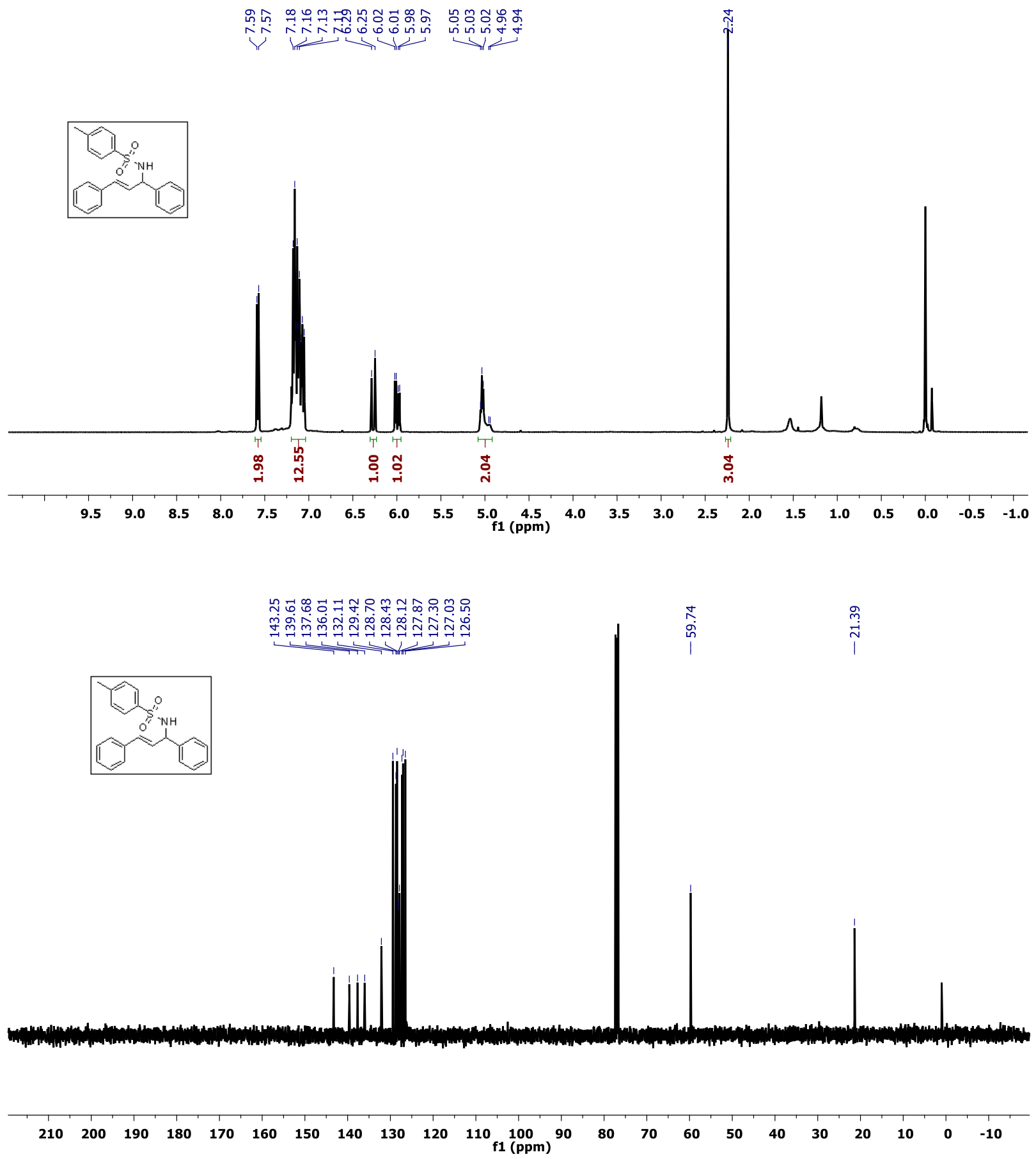
DEPT spectra of compound 3aa:

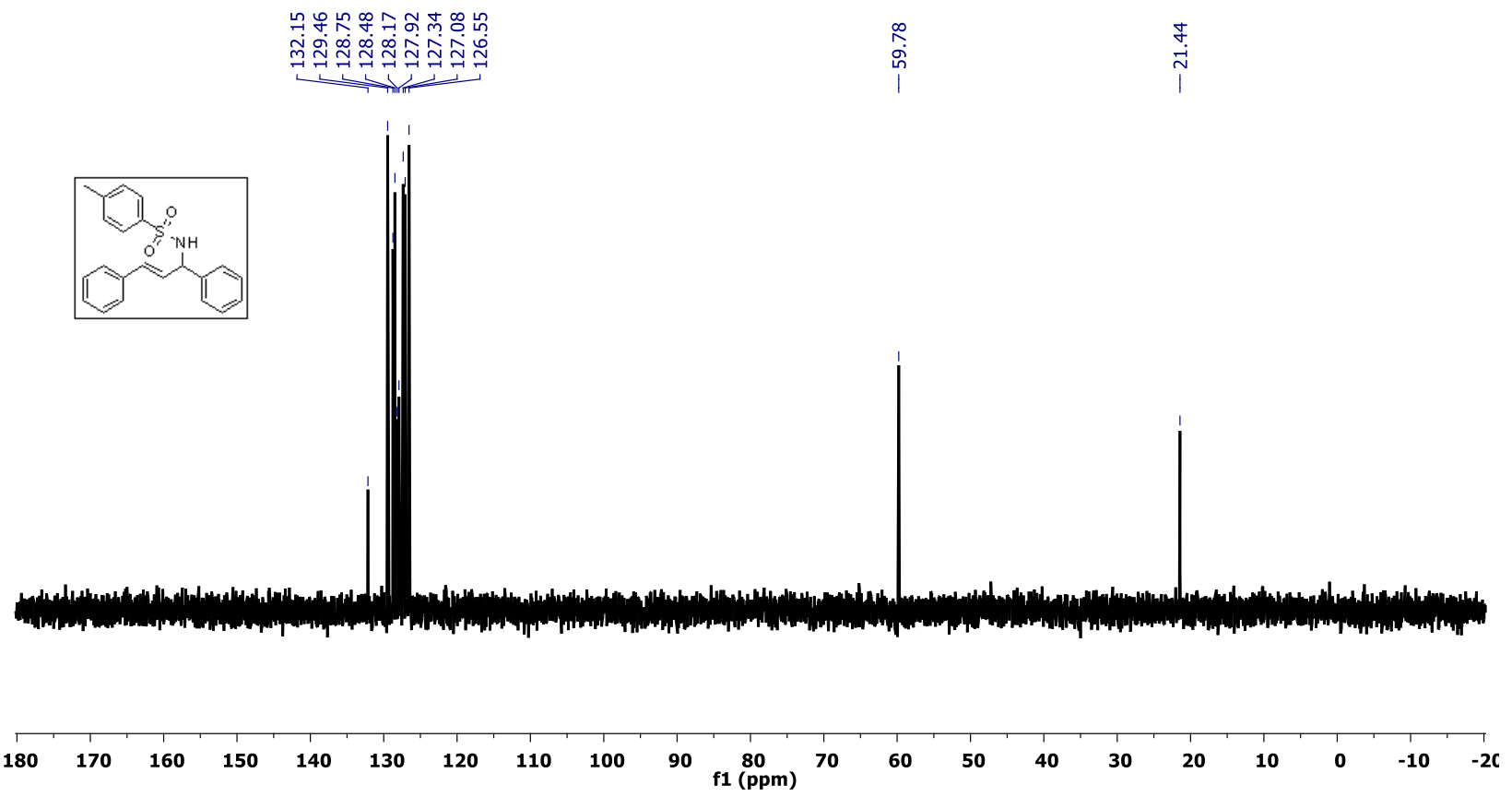


${ }^{1} \mathrm{H}$ and ${ }^{13} \mathrm{C}$ spectra of compound 3ab:
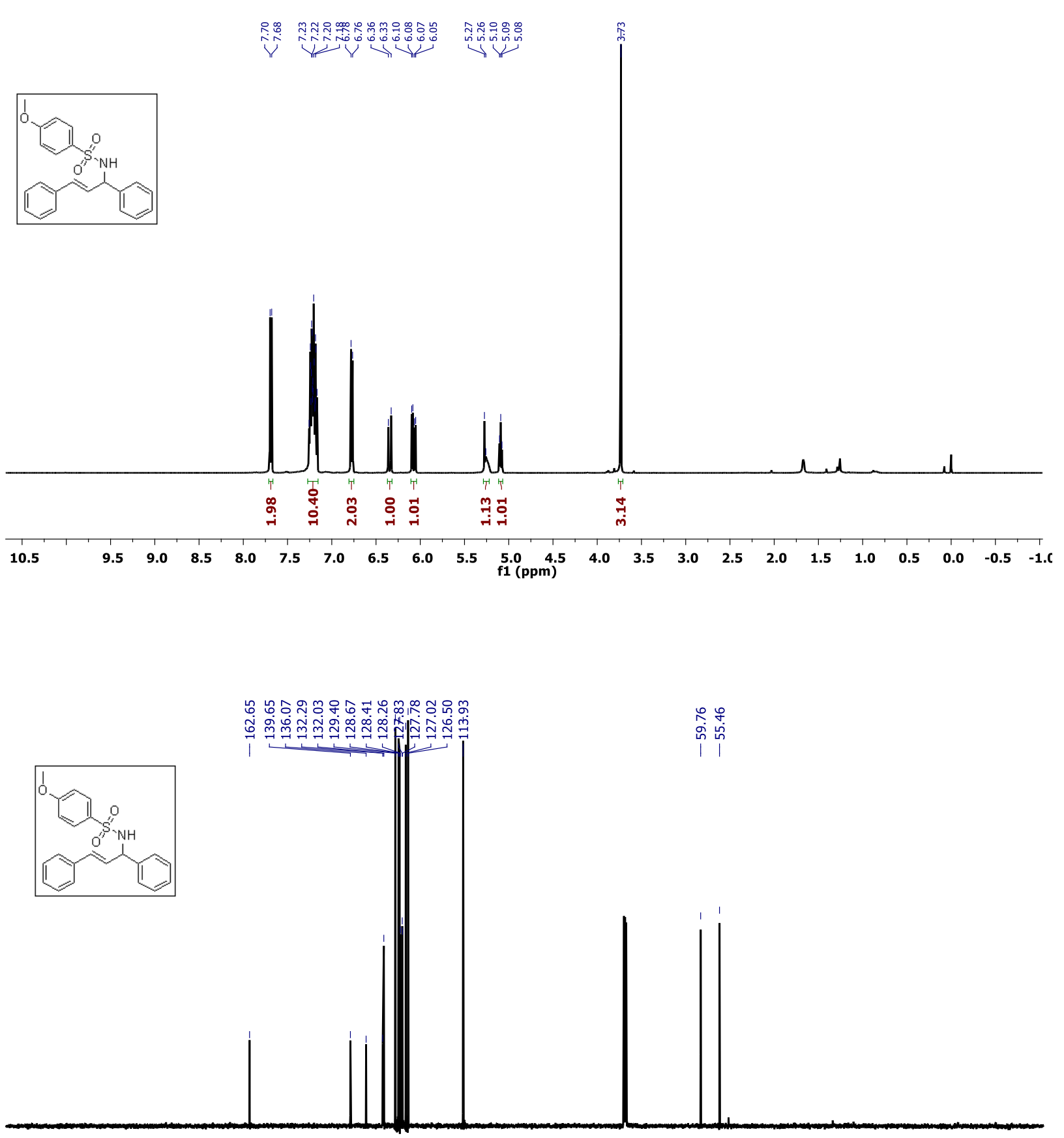

$\begin{array}{lllllllllllllllllllllllll}10 & 200 & 190 & 180 & 170 & 160 & 150 & 140 & 130 & 120 & 110 & \underset{\mathrm{f} 1(\mathrm{ppm})}{100} & 90 & 80 & 70 & 60 & 50 & 40 & 30 & 20 & 10 & 0 & -10\end{array}$ 
DEPT spectra of compound 3ab:
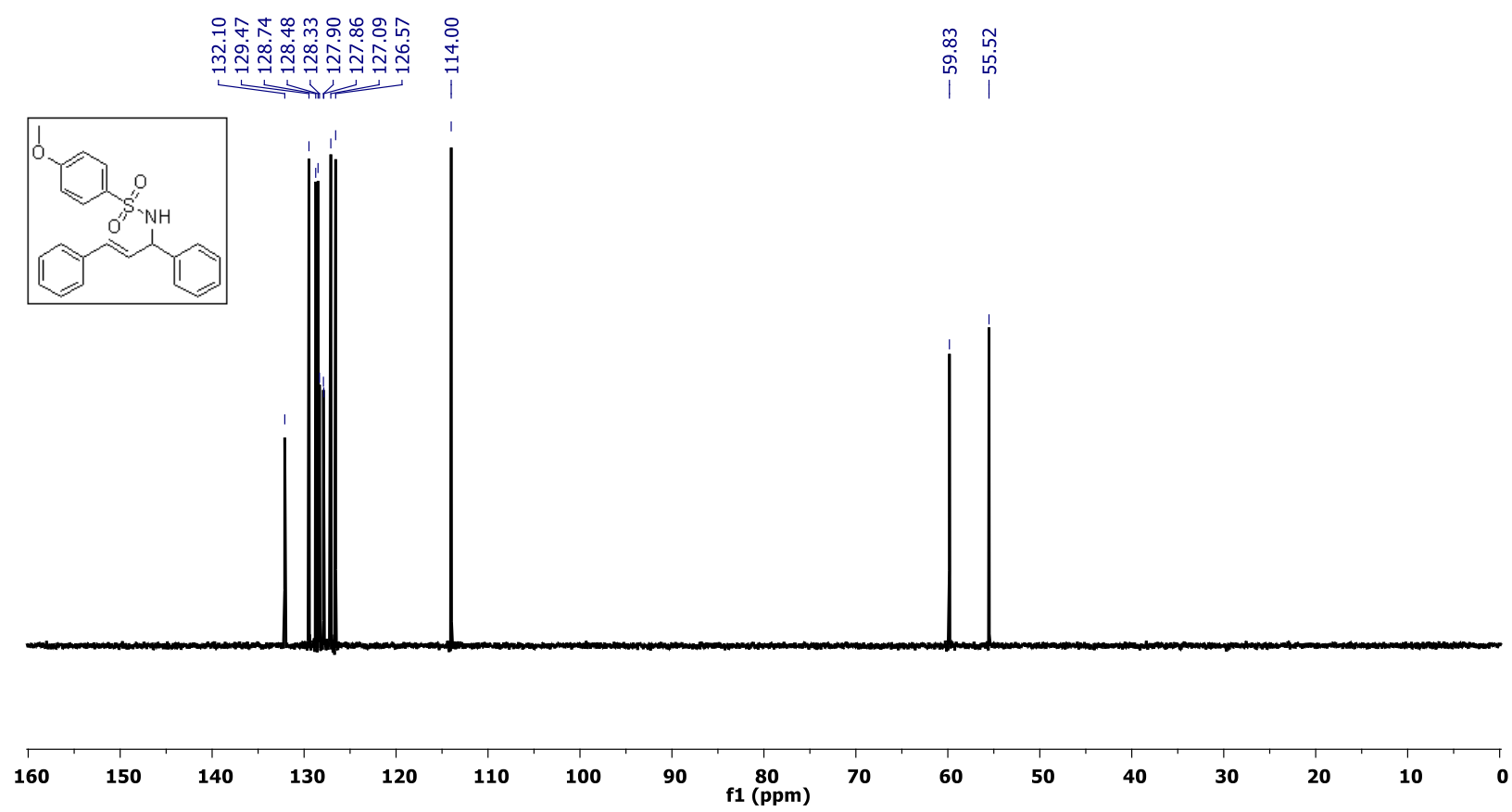
${ }^{1} \mathrm{H}$ and ${ }^{13} \mathrm{C}$ spectra of compound 3ac:
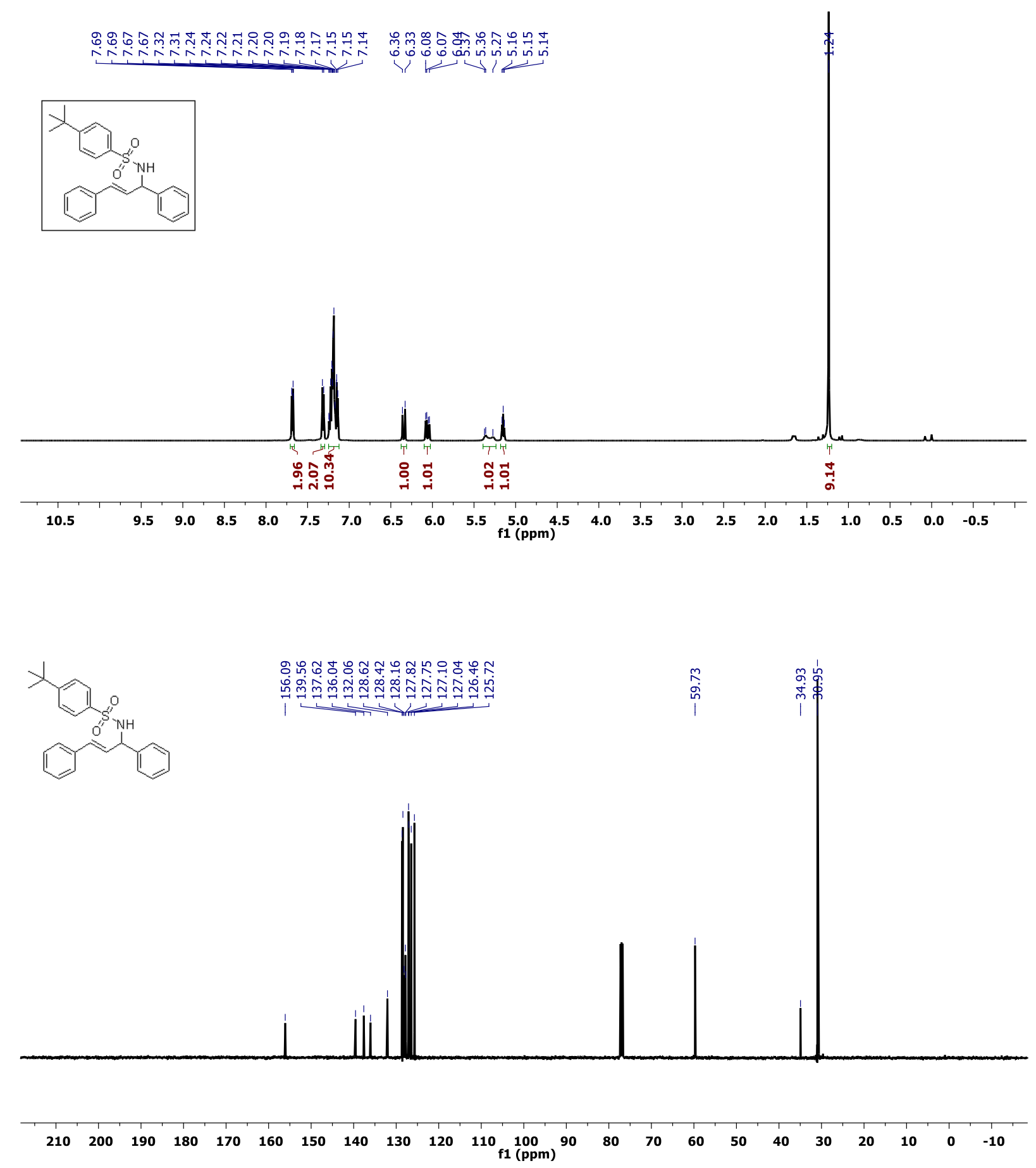
DEPT spectra of compound 3ac:

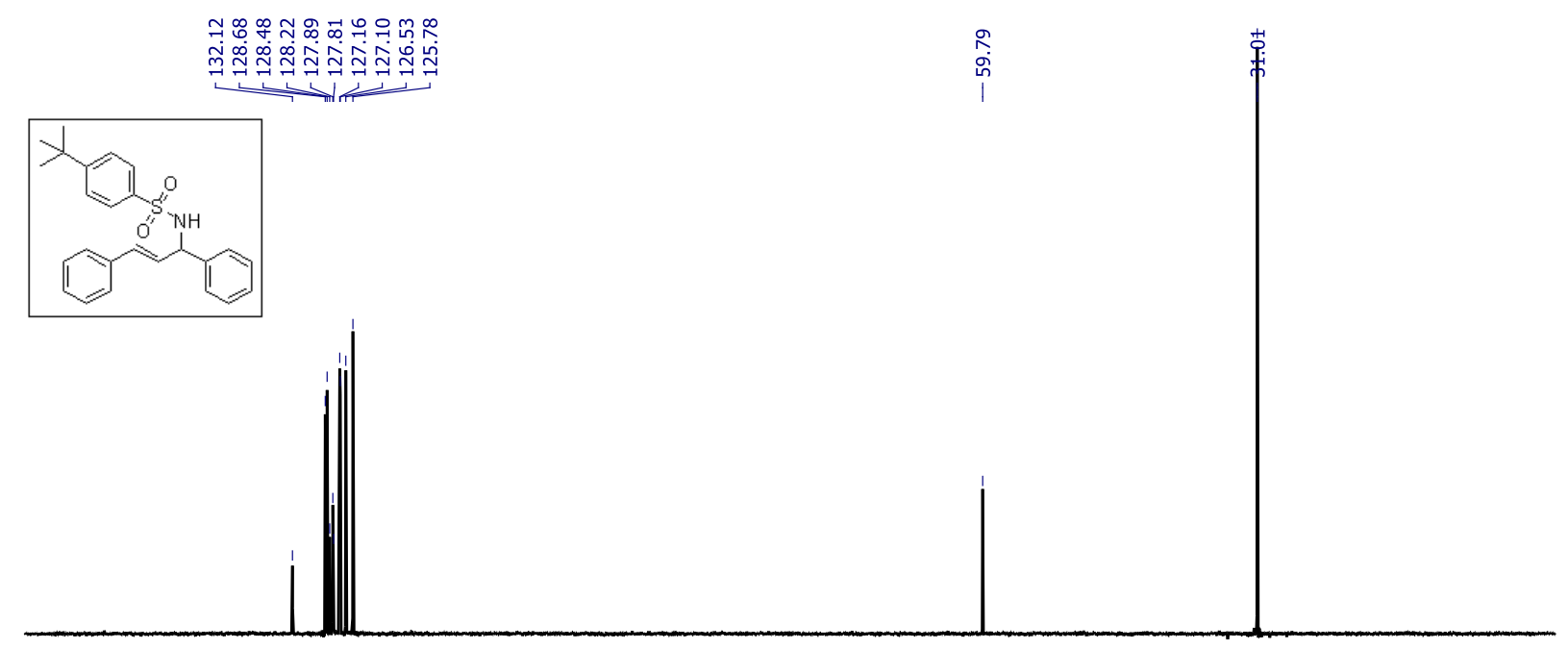

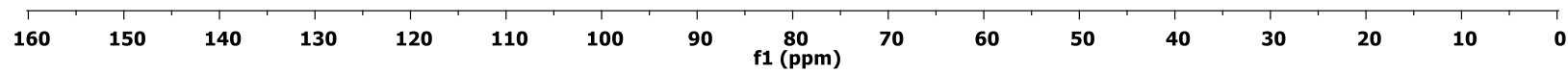




\section{${ }^{1} \mathrm{H}$ and ${ }^{13} \mathrm{C}$ spectra of compound 3ad:}
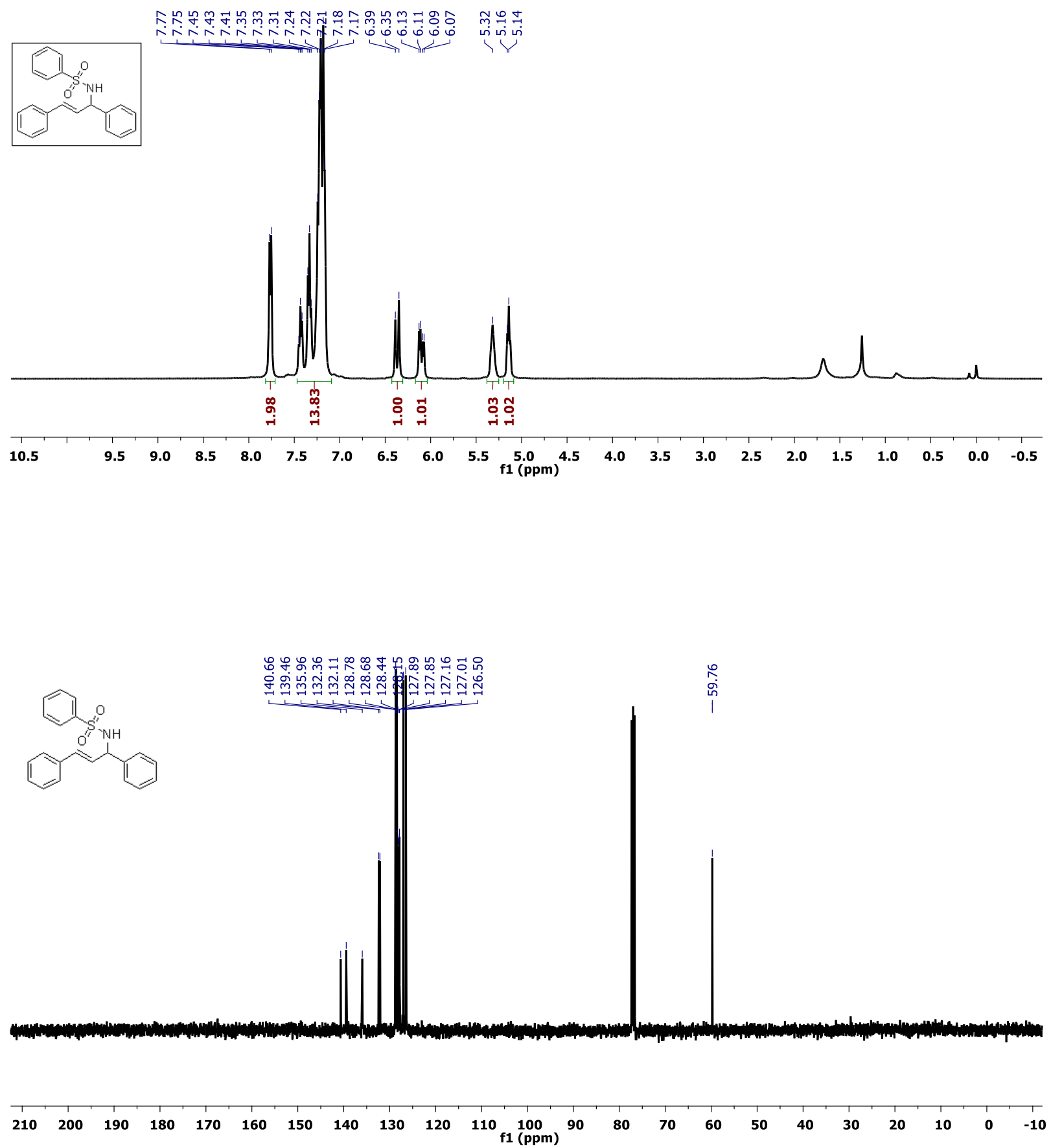
DEPT spectra of compound 3ad:

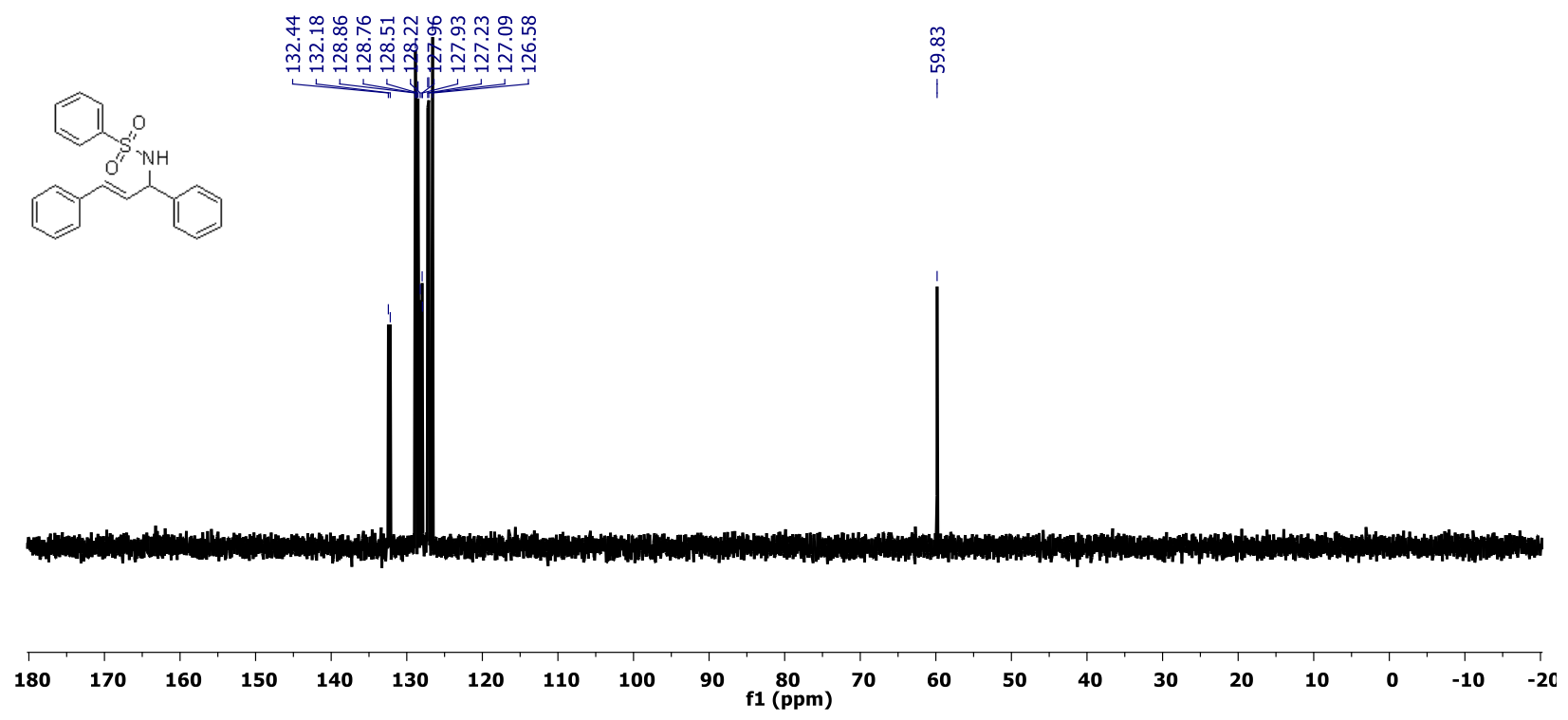


${ }^{1} \mathrm{H}$ and ${ }^{13} \mathrm{C}$ spectra of compound 3ae:
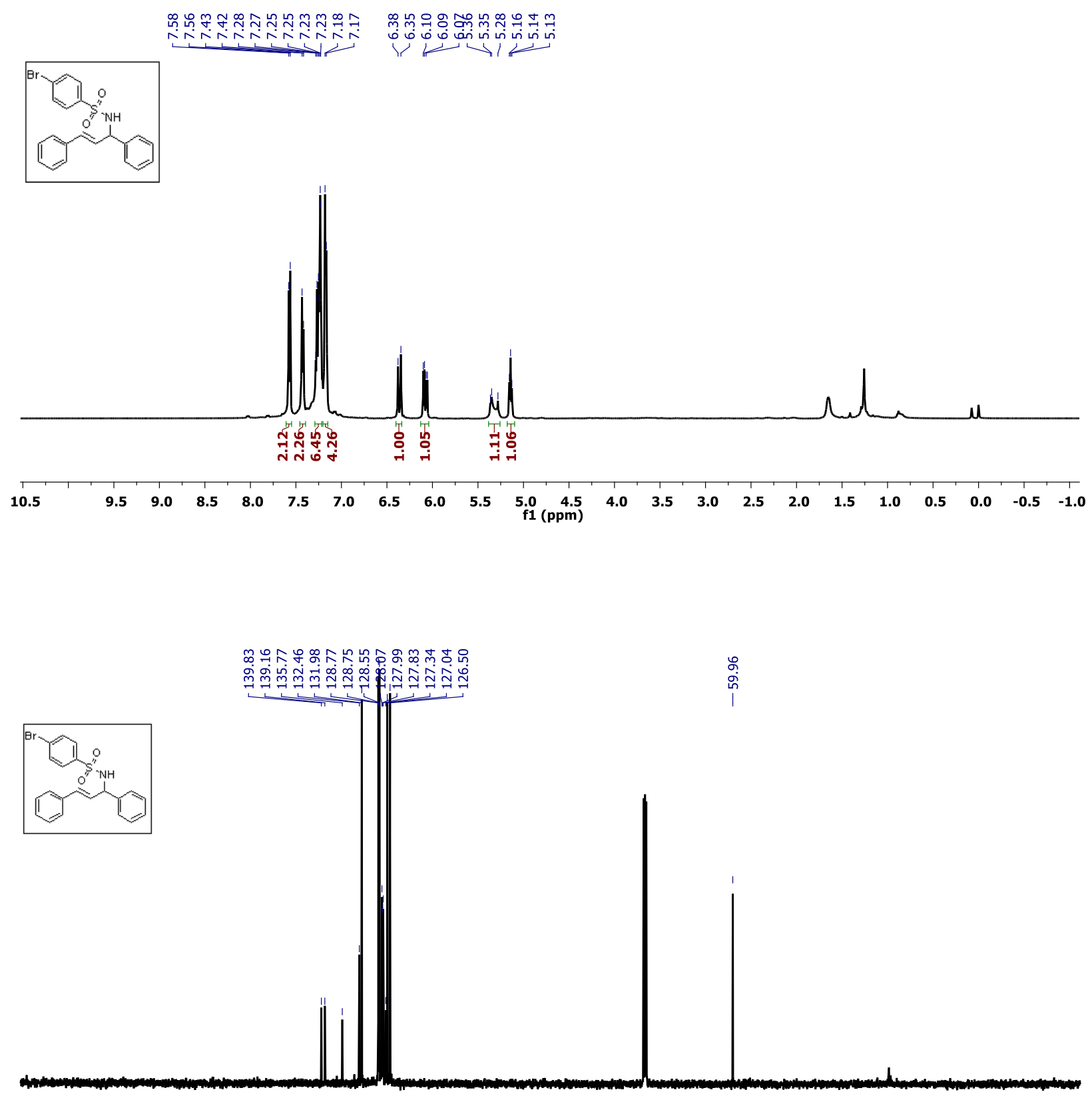

190

180170

160

150140

$130 \quad 12$

110

$100 \underset{\text { f1 }}{90} 9$

8070

6050

$40 \quad 30$

20

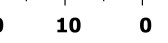


DEPT spectra of compound 3ae:

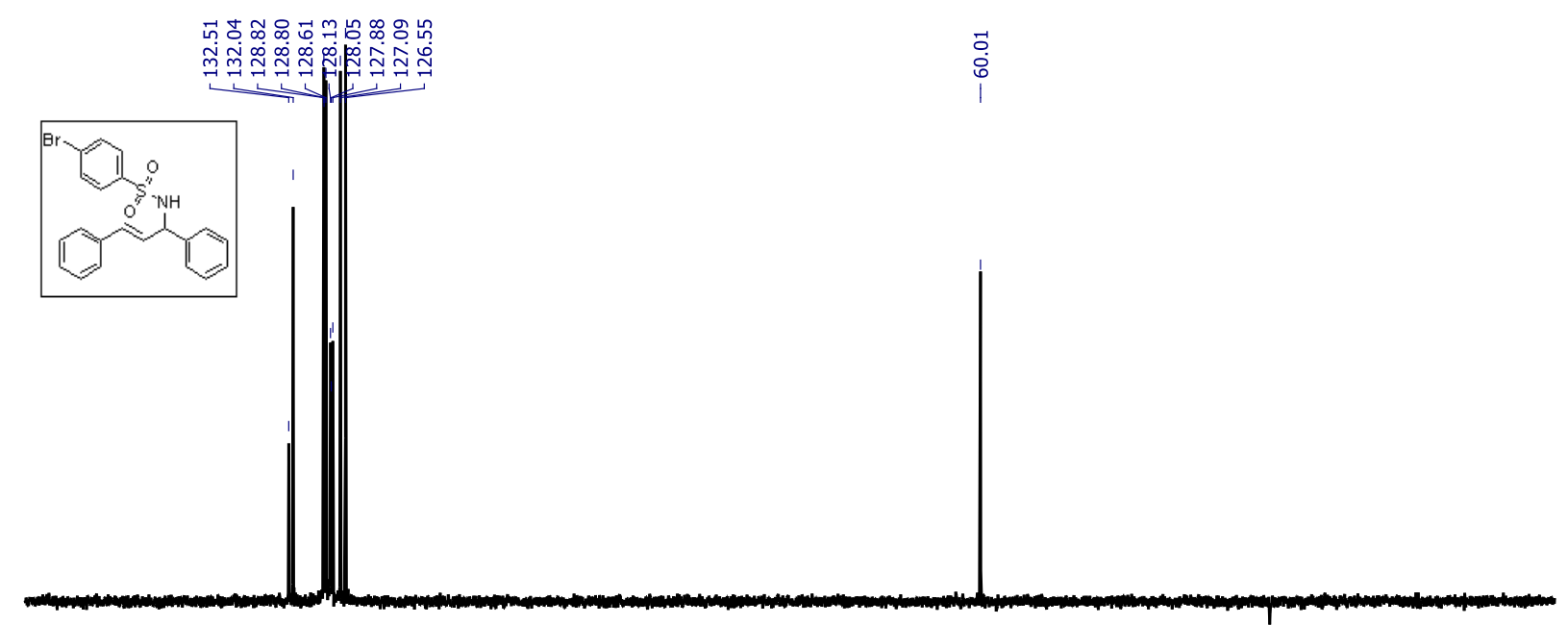

\begin{tabular}{|c|c|c|c|c|c|c|c|c|c|c|c|c|c|c|c|}
\hline 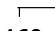 & 1 & 1 & 1 & 1 & 1 & 1 & 1 & 1 & 1 & 1 & 1 & 1 & 1 & 1 & 1 \\
\hline 160 & 150 & 140 & 130 & 120 & 110 & 100 & 90 & $\begin{array}{c}80 \\
\text { f1 (ppm) }\end{array}$ & 70 & 60 & 50 & 40 & 30 & 20 & 10 \\
\hline
\end{tabular}




\section{${ }^{1} \mathrm{H}$ and ${ }^{13} \mathrm{C}$ spectra of compound 3af:}
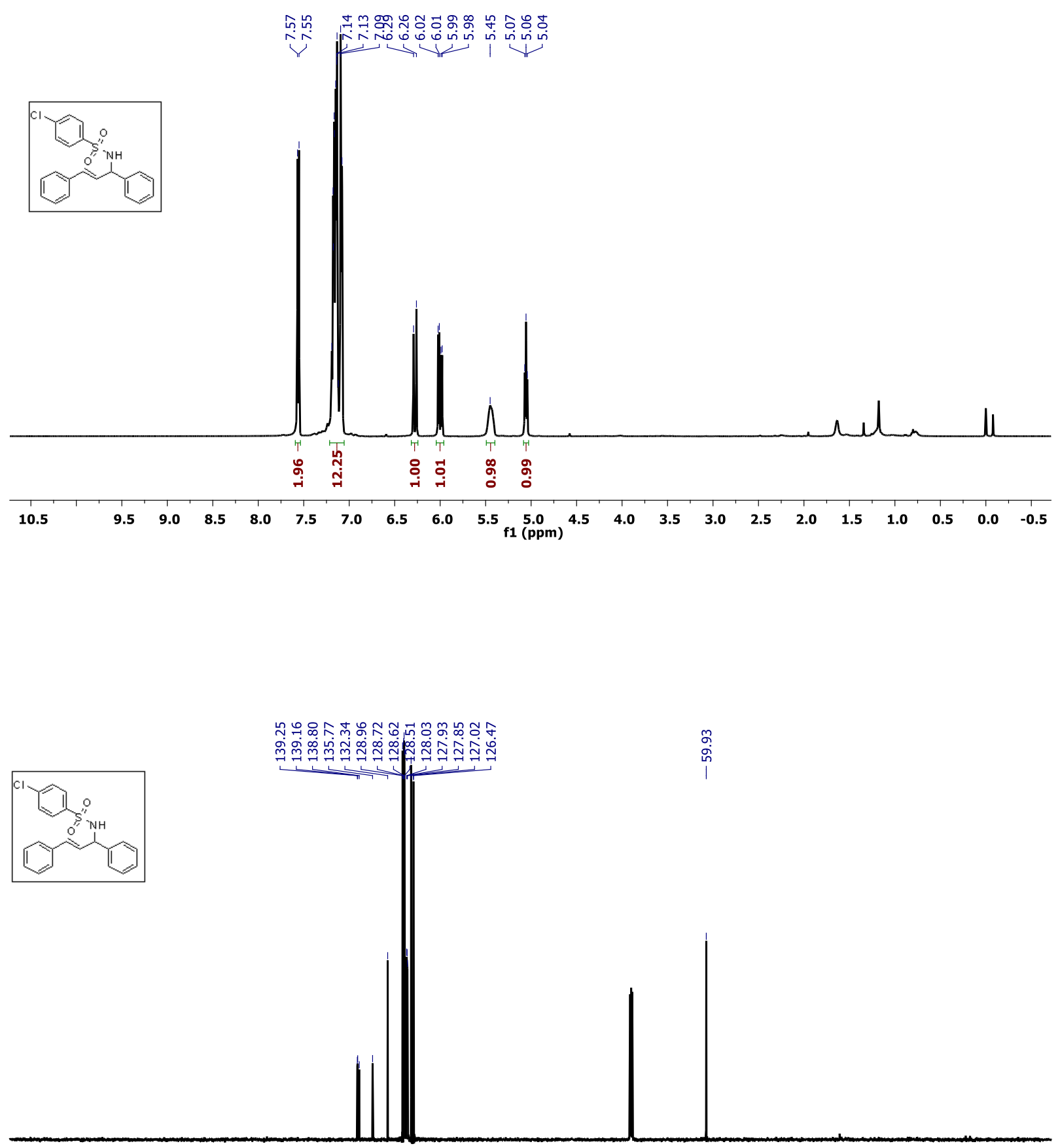

$\begin{array}{llllllllllllllllllllll}210 & 200 & 190 & 180 & 170 & 160 & 150 & 140 & 130 & 120 & 110 \underset{f 1}{100}(\mathrm{ppm}) & 90 & 80 & 70 & 60 & 50 & 40 & 30 & 20 & 10 & 0 & -10\end{array}$ 


\section{DEPT spectra of compound 3af:}

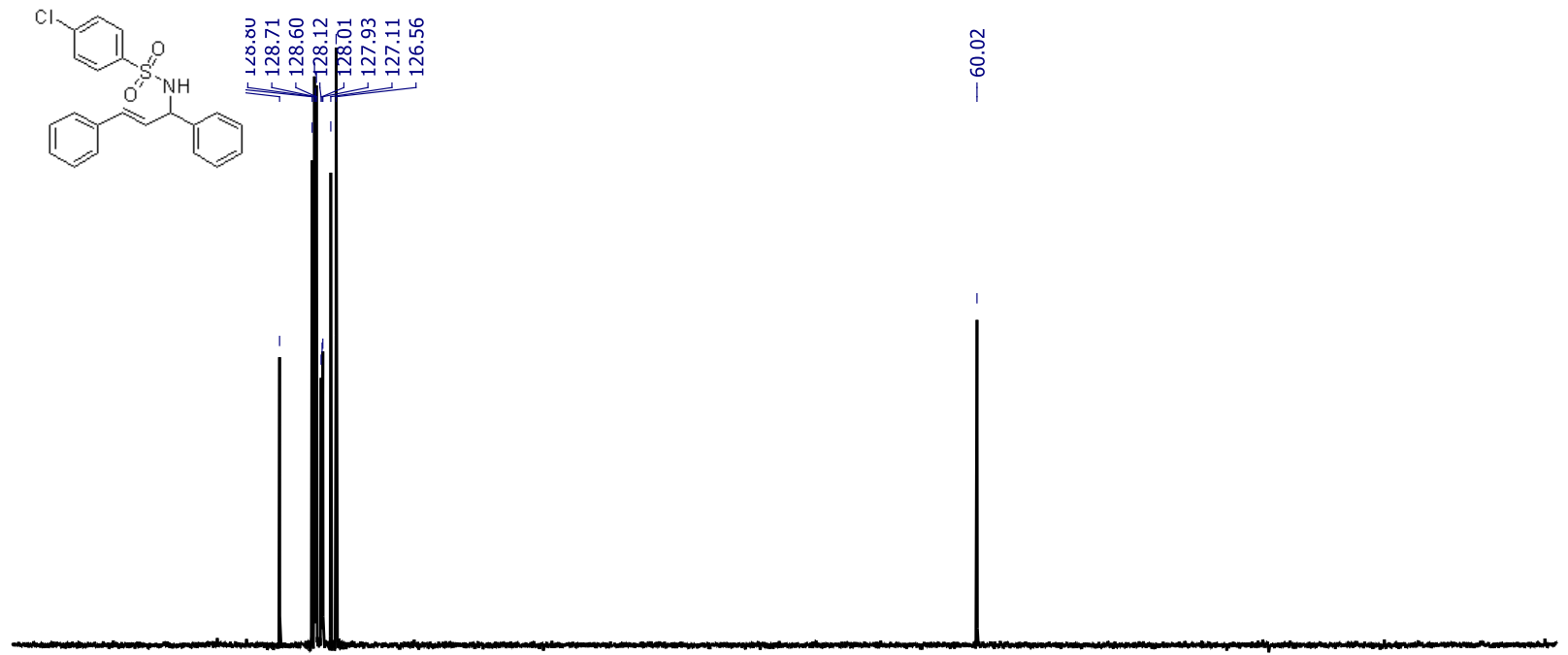

\begin{tabular}{lllllllllllllllll}
\hline 160 & 150 & 140 & 130 & 120 & 110 & 100 & 90 & $\begin{array}{c}80 \\
\mathrm{f} 1(\mathrm{ppm})\end{array}$ & 70 & 60 & 50 & 40 & 30 & 20 & 10 & 0
\end{tabular}


${ }^{1} \mathrm{H}$ and ${ }^{13} \mathrm{C}$ spectra of compound 3ag:
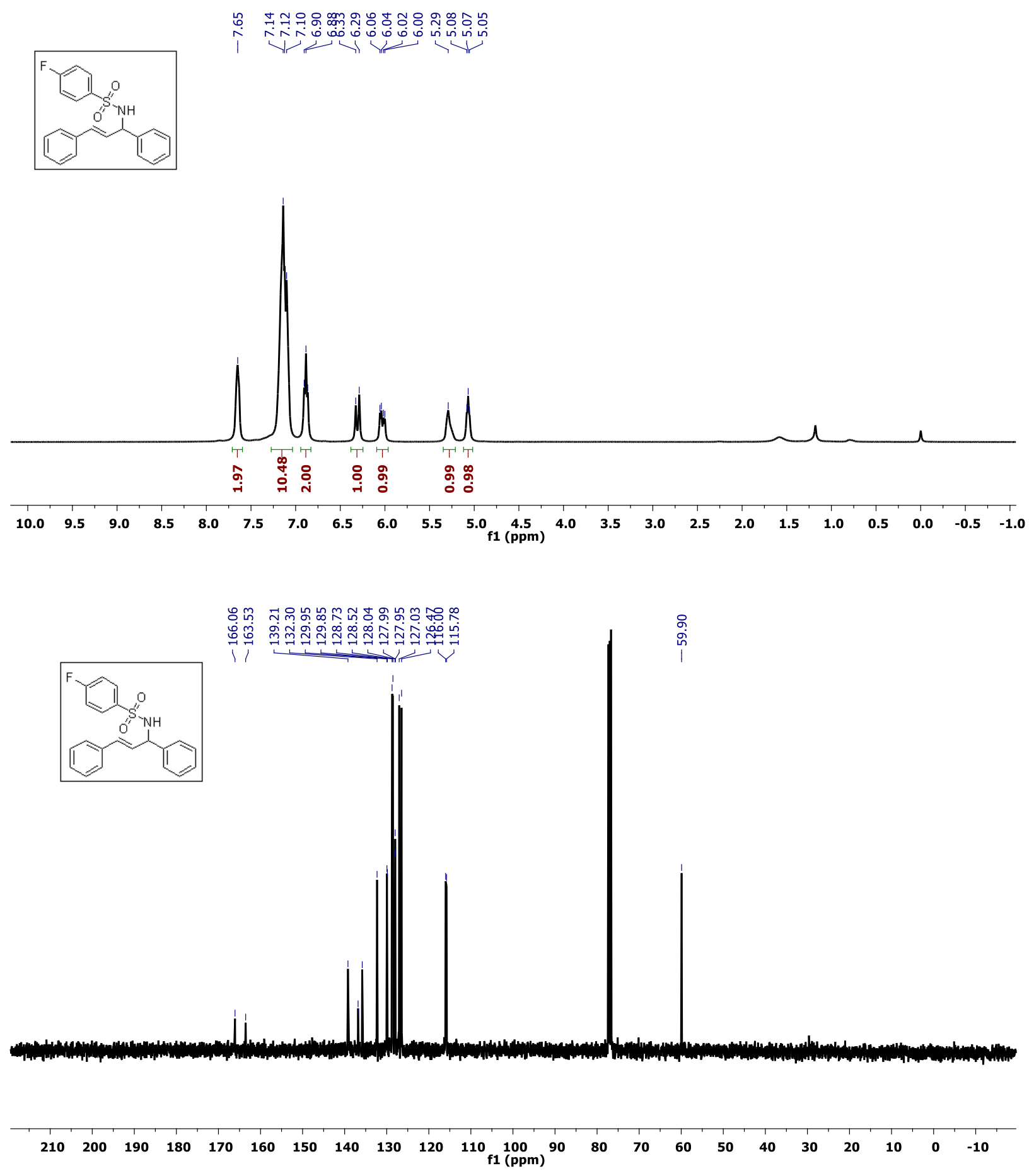
DEPT spectra of compound 3ag:

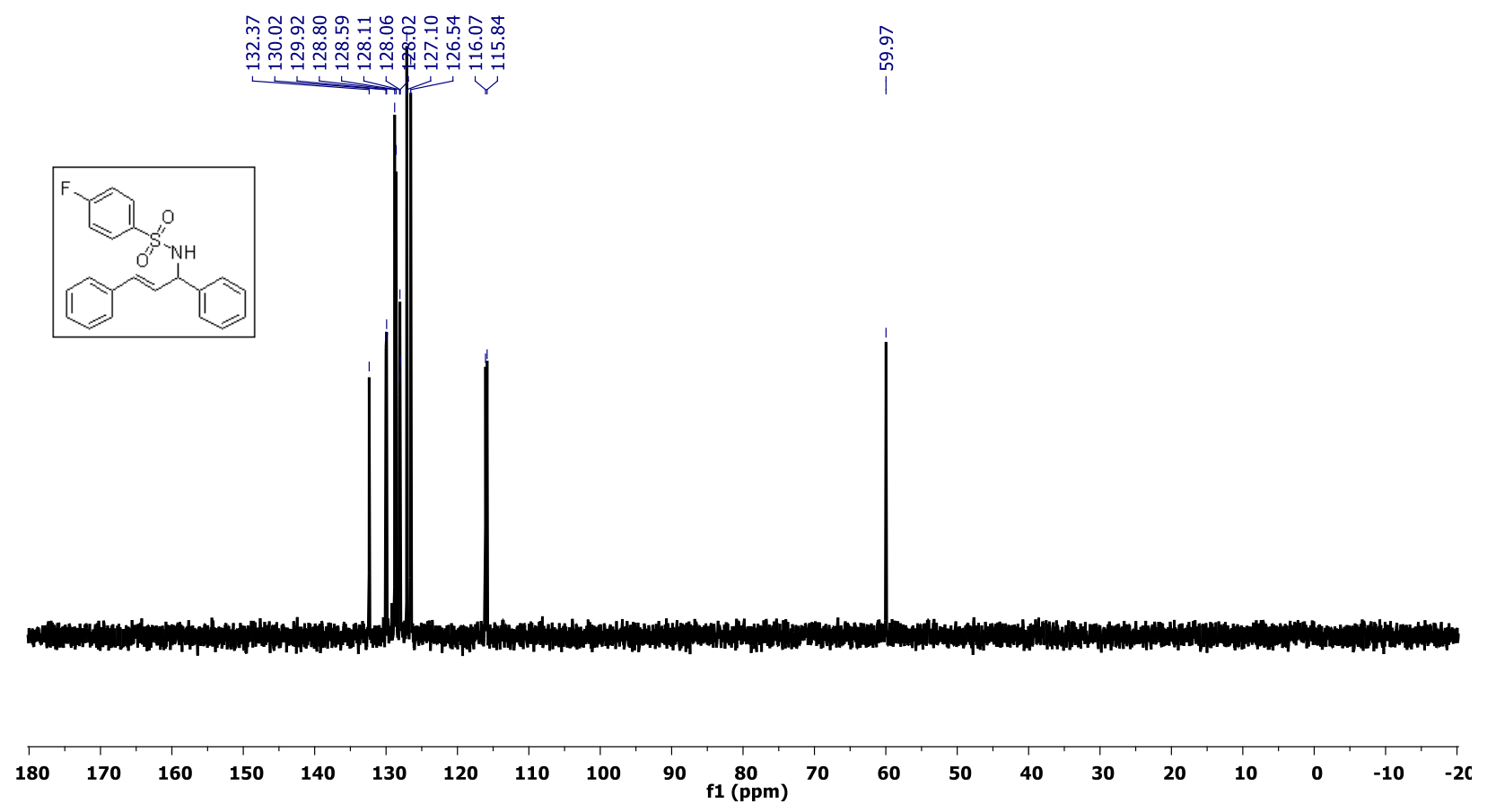

${ }^{19}$ F spectra of compound 3ag:

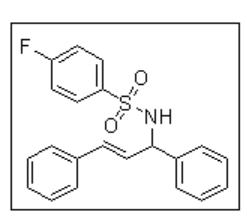

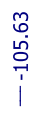

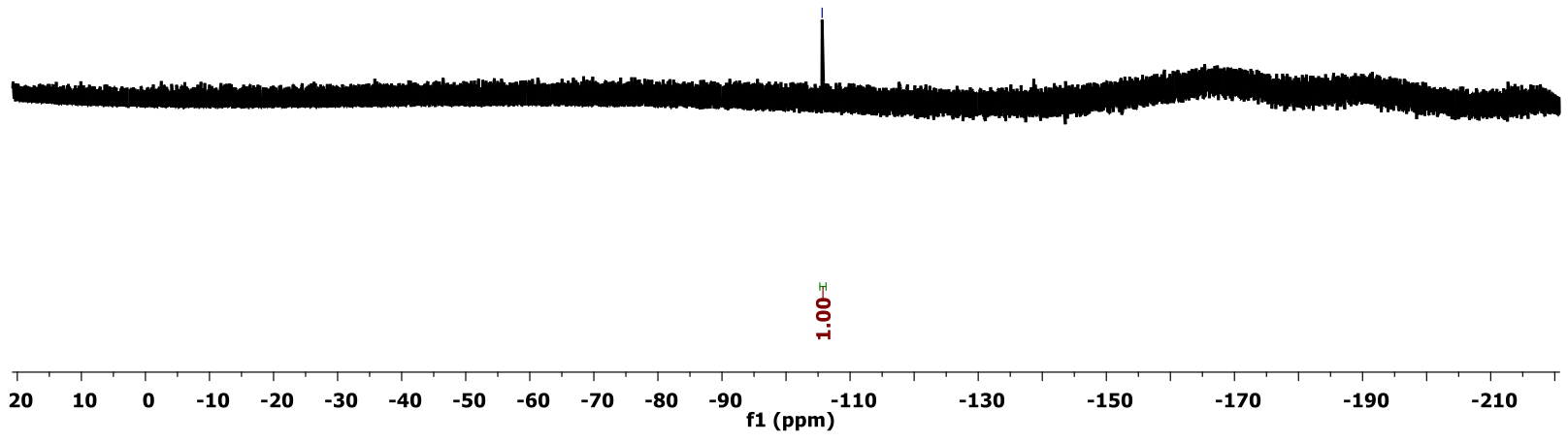


${ }^{1} \mathrm{H}$ and ${ }^{13} \mathrm{C}$ spectra of compound 3ah:
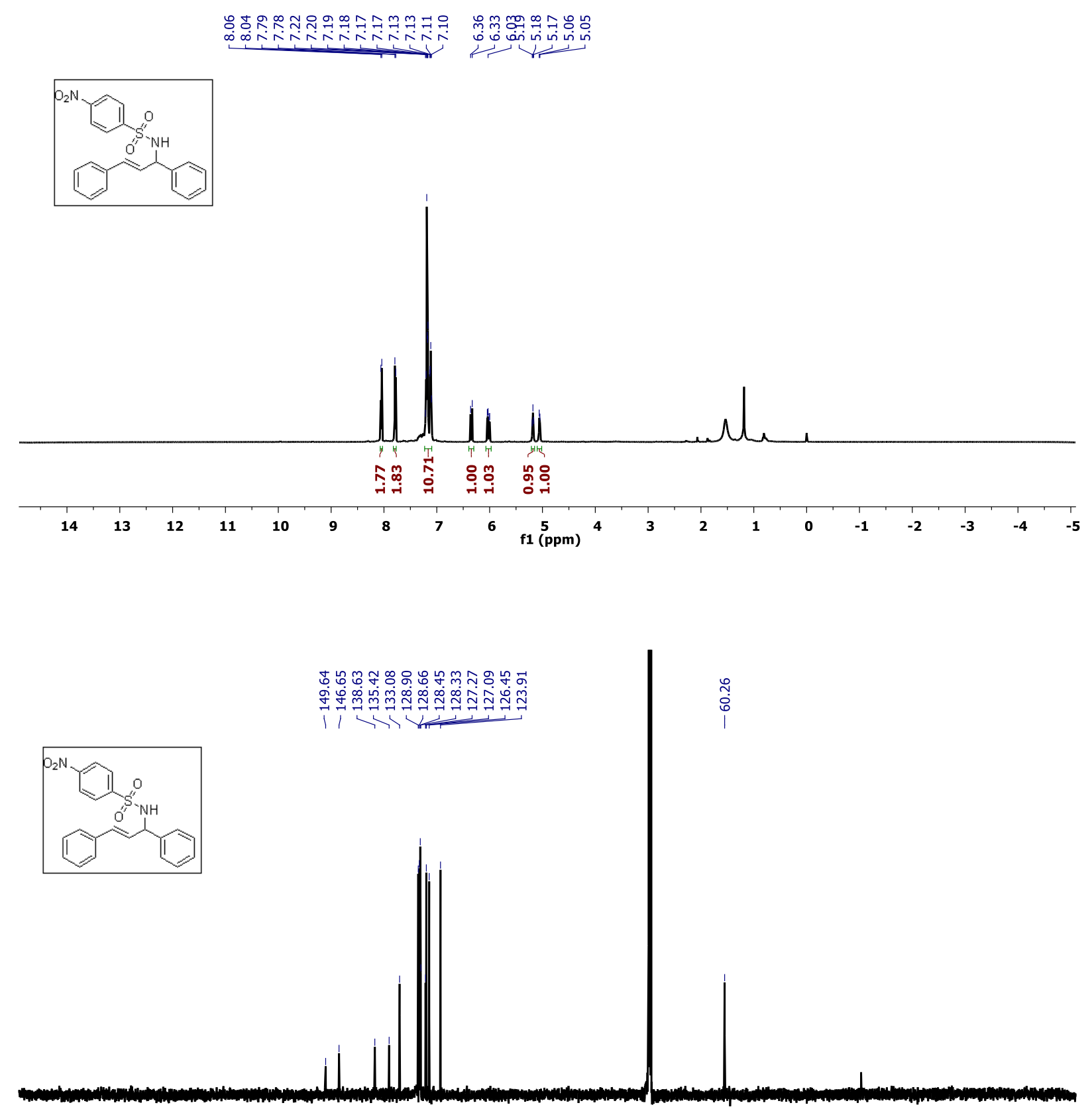

$\begin{array}{lllllllllllllllllllllllllllll}210 & 200 & 190 & 180 & 170 & 160 & 150 & 140 & 130 & 120 & 110 & 100 & 90 & 80 & 70 & 60 & 50 & 40 & 30 & 20 & 10 & 0 & -10\end{array}$ 
DEPT spectra of compound 3ah:

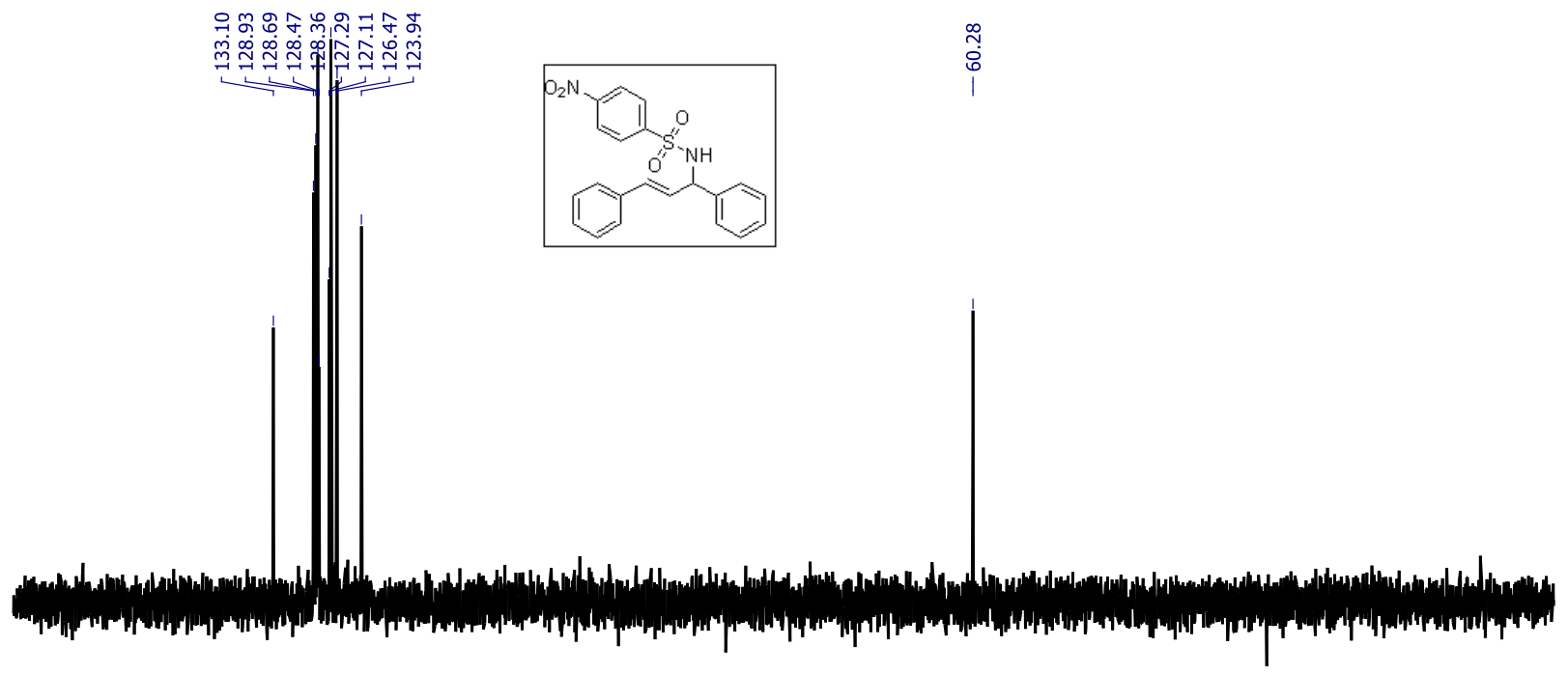




\section{${ }^{1} \mathrm{H}$ and ${ }^{13} \mathrm{C}$ spectra of compound 3ai:}

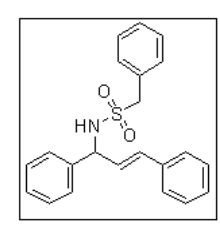

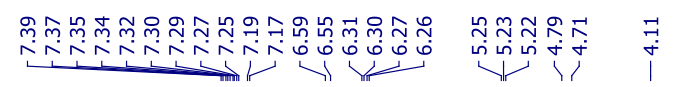
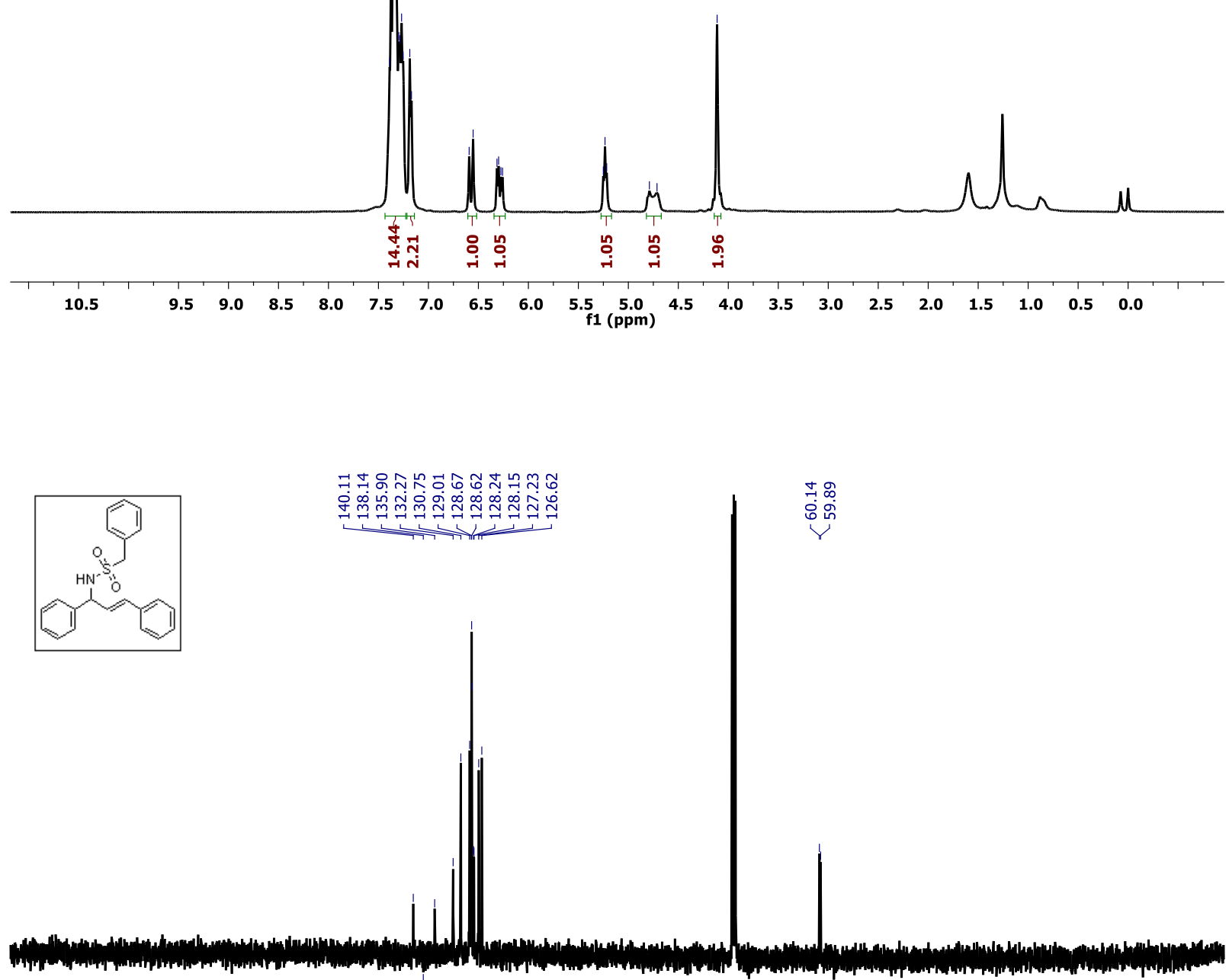

$\begin{array}{lllllllllllllllllllllllll}210 & 200 & 190 & 180 & 170 & 160 & 150 & 140 & 130 & 120 & 110 & \underset{f 1}{100}(\mathrm{ppm}) & 90 & 80 & 70 & 60 & 50 & 40 & 30 & 20 & 10 & 0 & -10 & \end{array}$ 
DEPT spectra of compound 3ai:

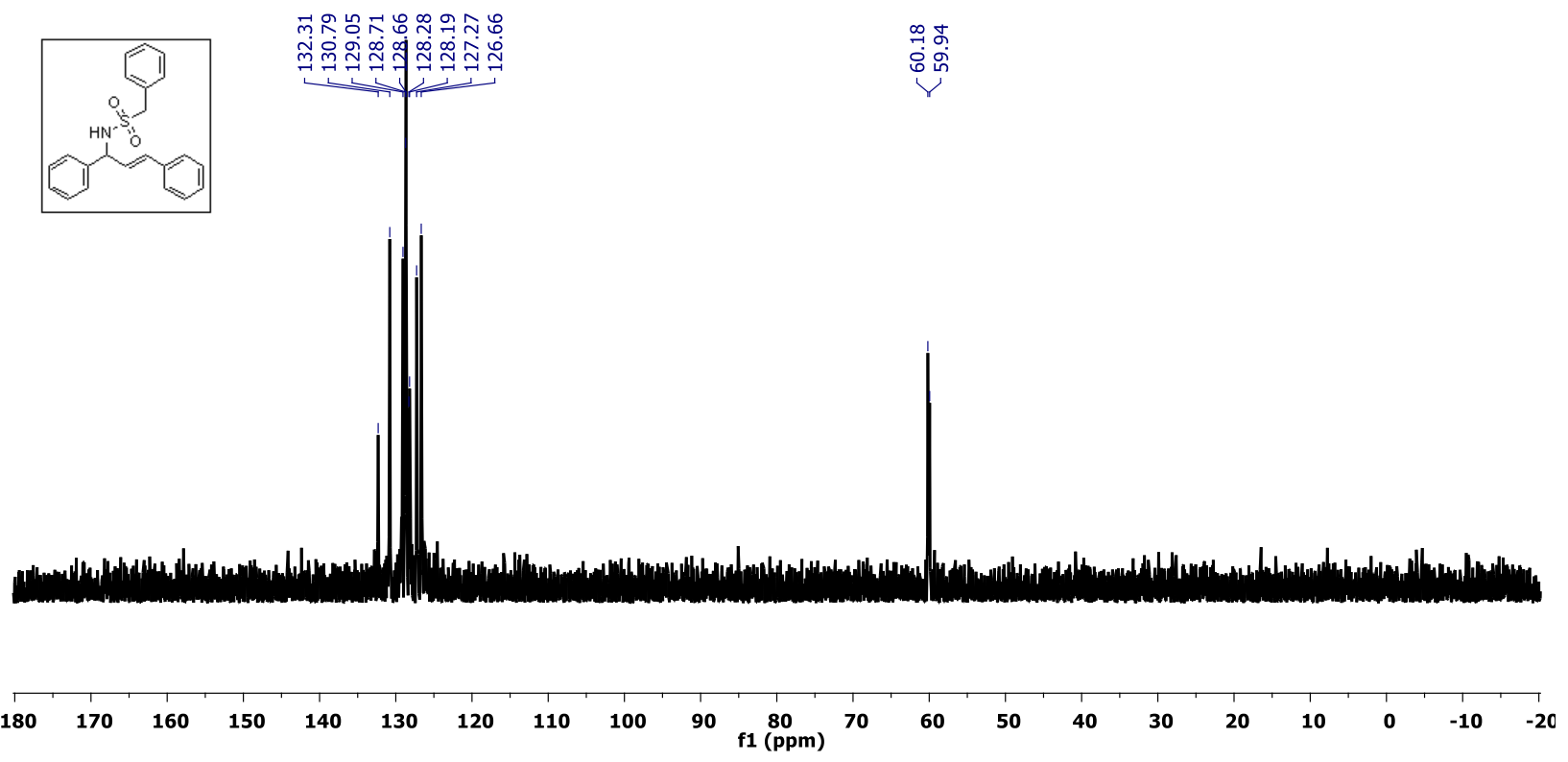


${ }^{1} \mathrm{H}$ and ${ }^{13} \mathrm{C}$ spectra of compound 3aj:
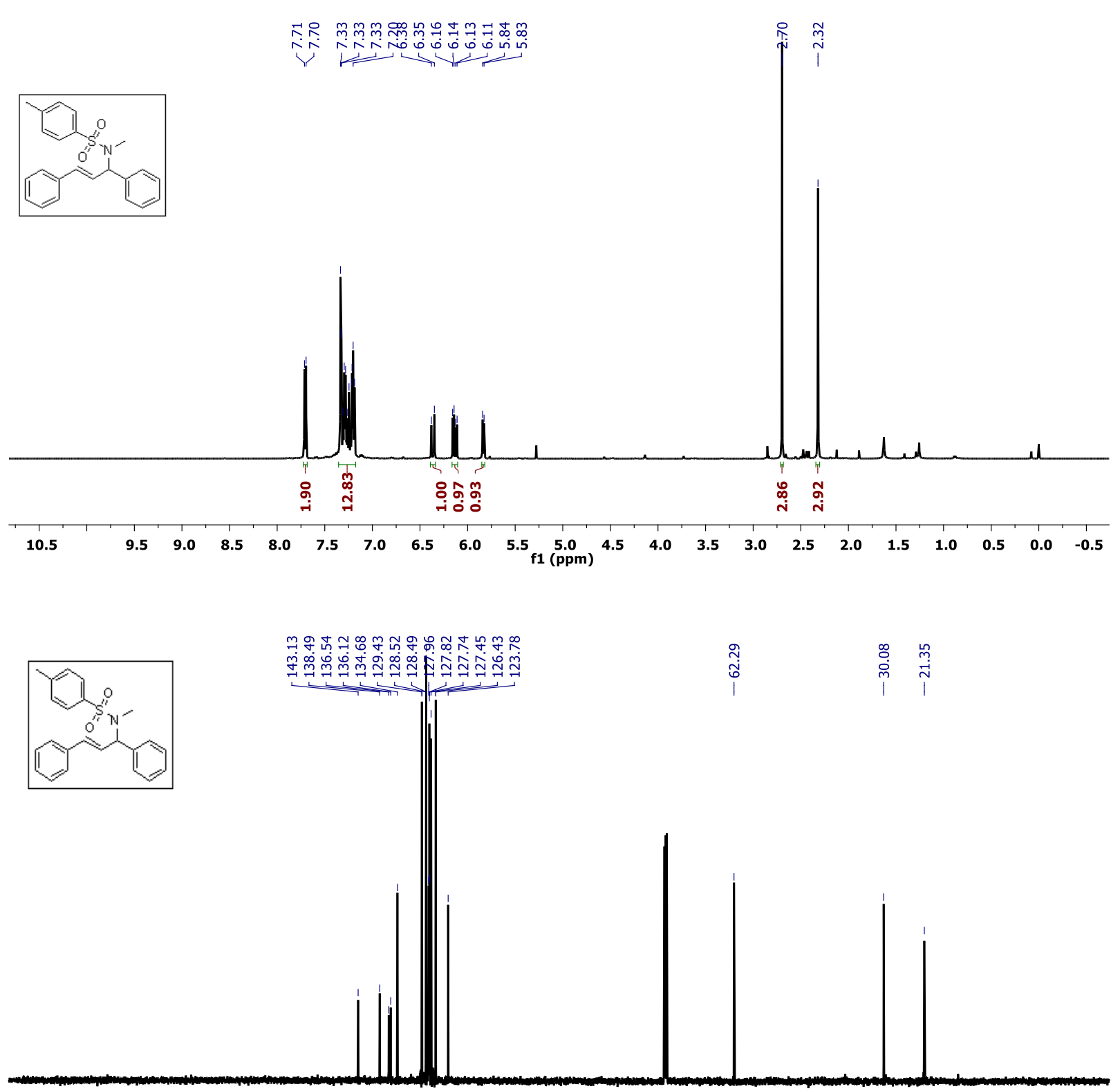

$\begin{array}{lllllllllllllllllllllllllllll}210 & 200 & 190 & 180 & 170 & 160 & 150 & 140 & 130 & 120 & 110 & \underset{f 1}{(\mathrm{ppm})} & 90 & 80 & 70 & 60 & 50 & 40 & 30 & 20 & 10 & 0 & -10 & \end{array}$ 
DEPT spectra of compound 3aj:
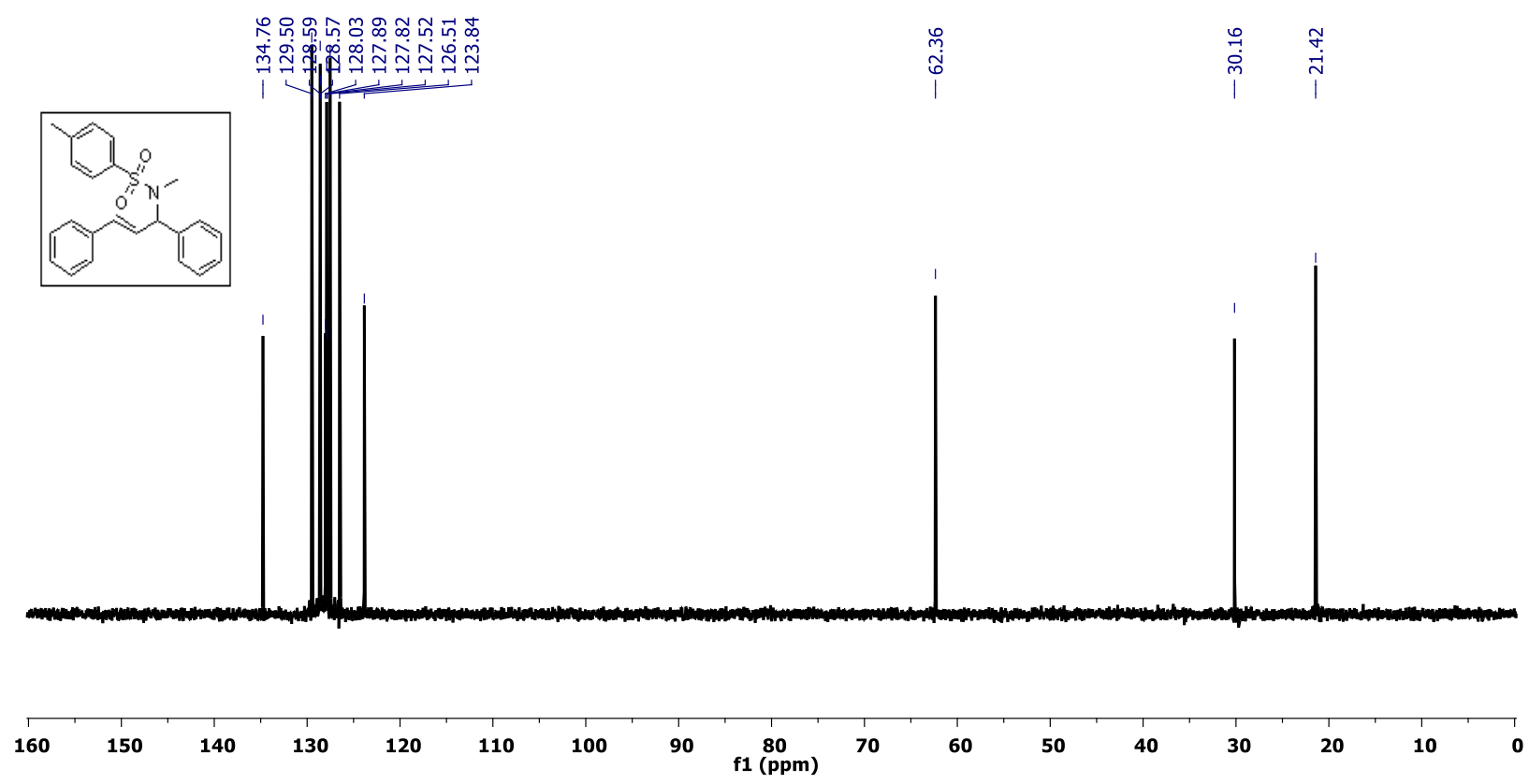
${ }^{1} \mathrm{H}$ and ${ }^{13} \mathrm{C}$ spectra of compound 3ak:
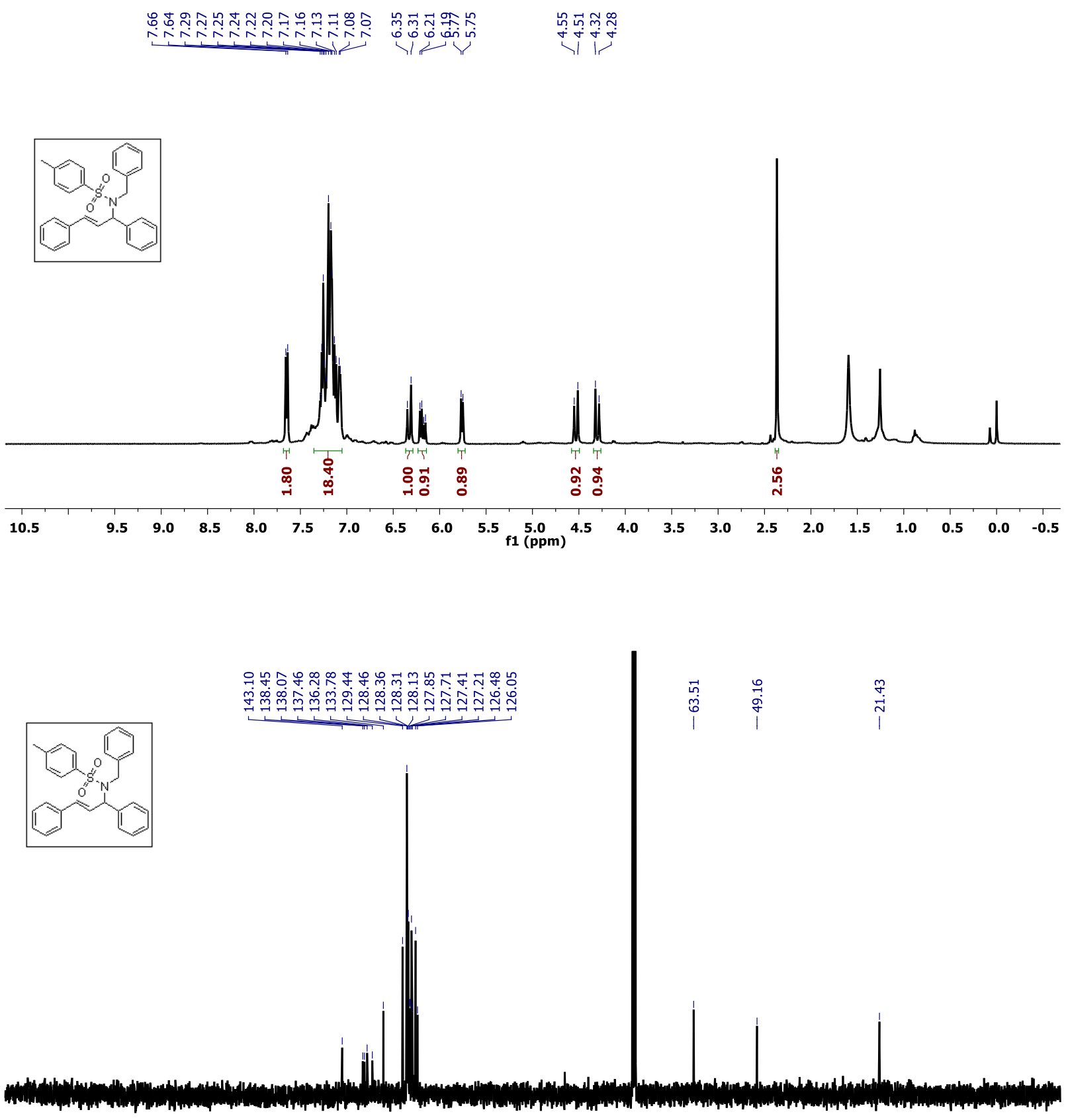

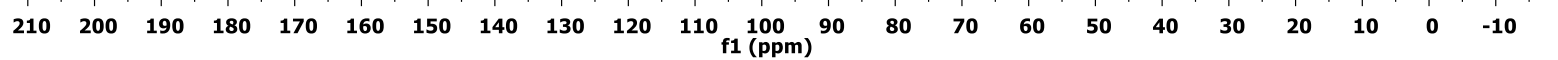


DEPT spectra of compound 3ak:

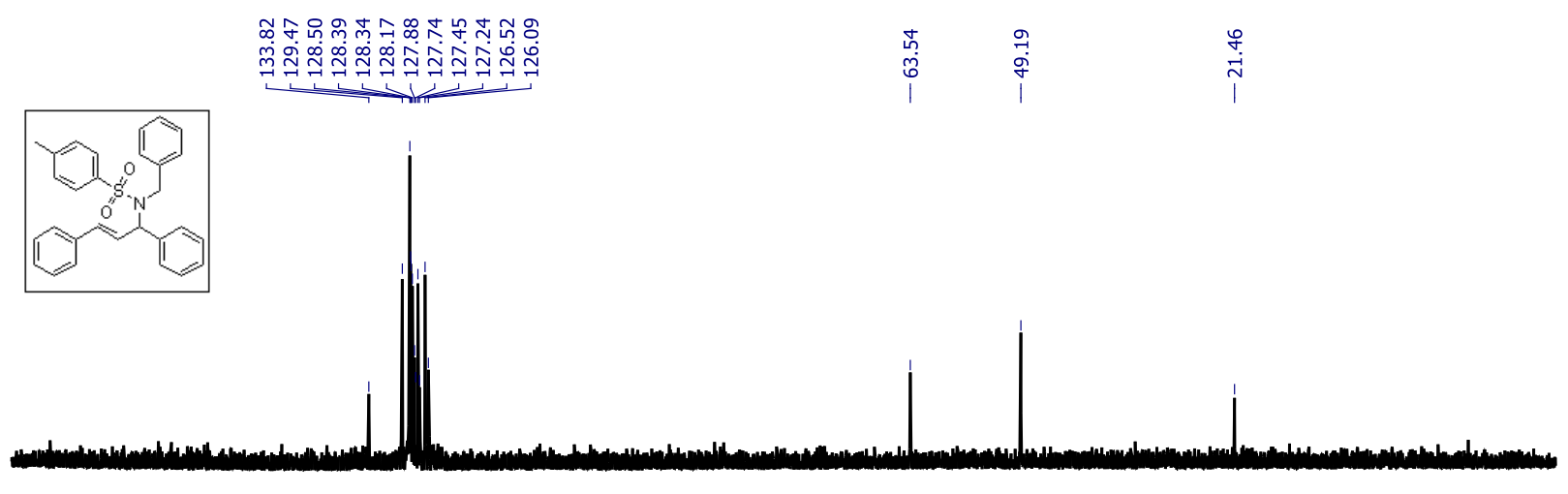

$\begin{array}{rrrrrrrrrrrrrrrrrrrrrrrrrrrr}180 & 170 & 160 & 150 & 140 & 130 & 120 & 110 & 100 & 90 & \begin{array}{c}80 \\ \text { f1 (ppm) }\end{array} & 70 & 60 & 50 & 40 & 30 & 20 & 10 & 0 & -10 & -2 C\end{array}$




\section{${ }^{1} \mathrm{H}$ and ${ }^{13} \mathrm{C}$ spectra of compound $3 \mathrm{al}$ :}
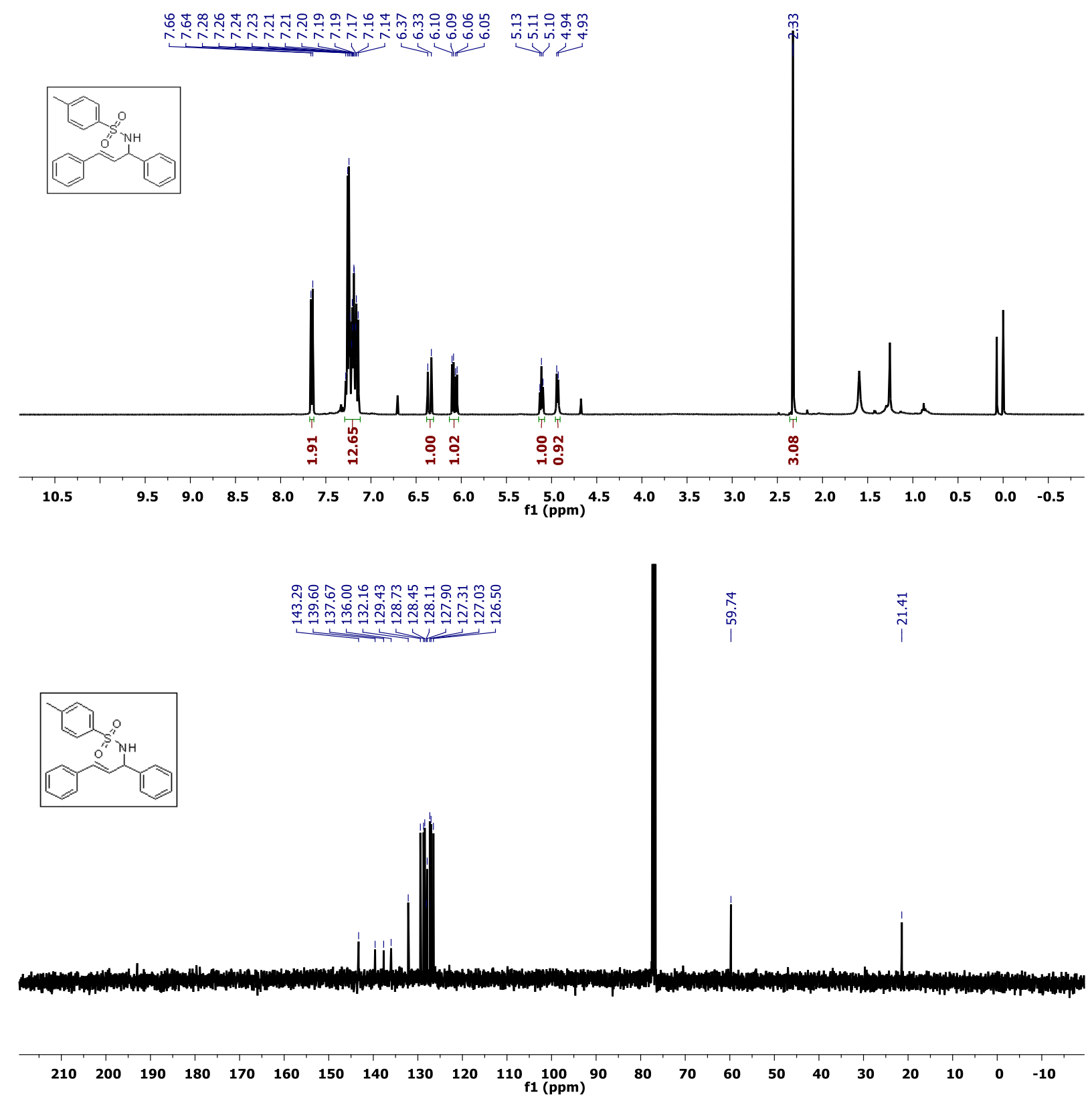
DEPT spectra of compound 3al:
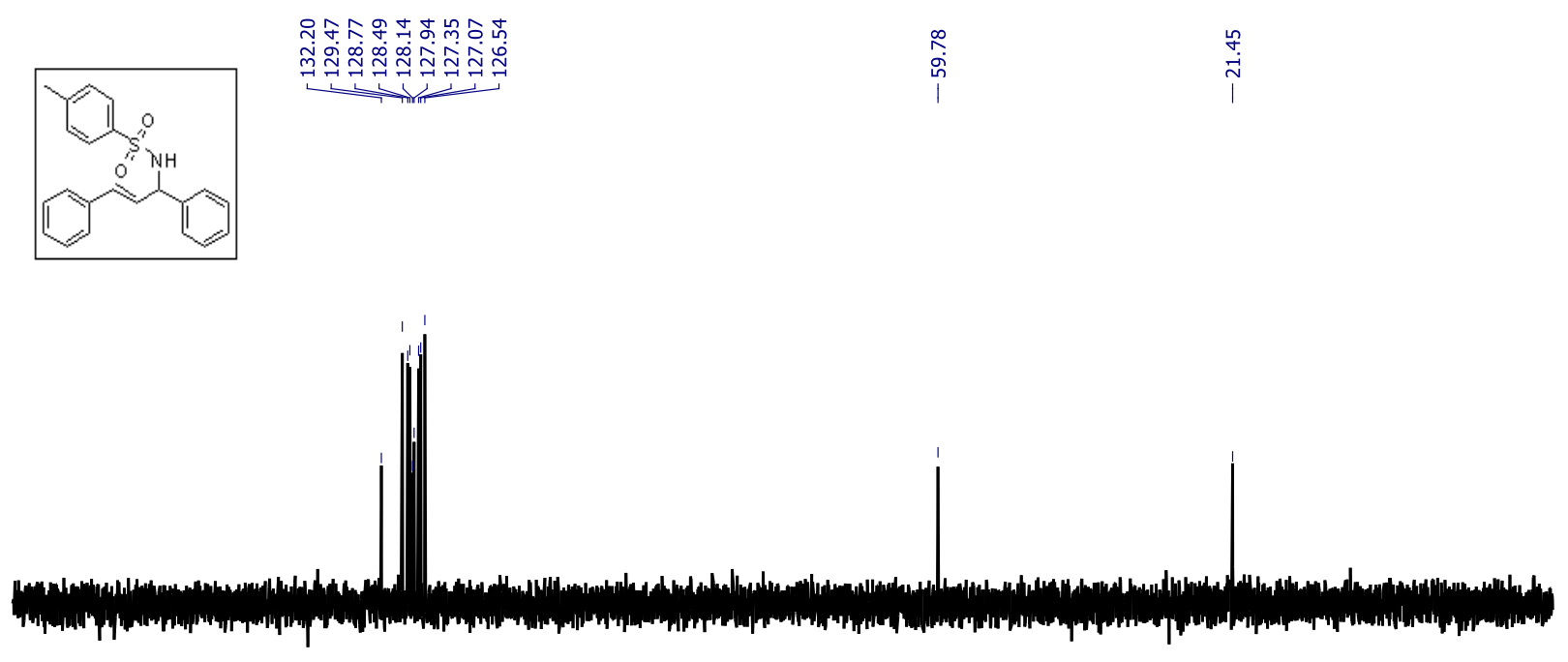

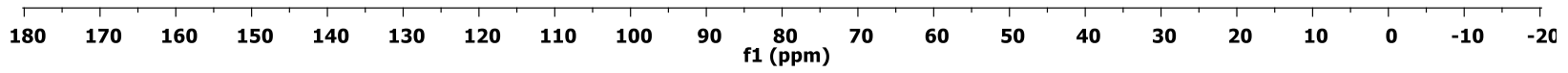




\section{${ }^{1} \mathrm{H}$ and ${ }^{13} \mathrm{C}$ spectra of compound $3 \mathrm{ba}$ :}
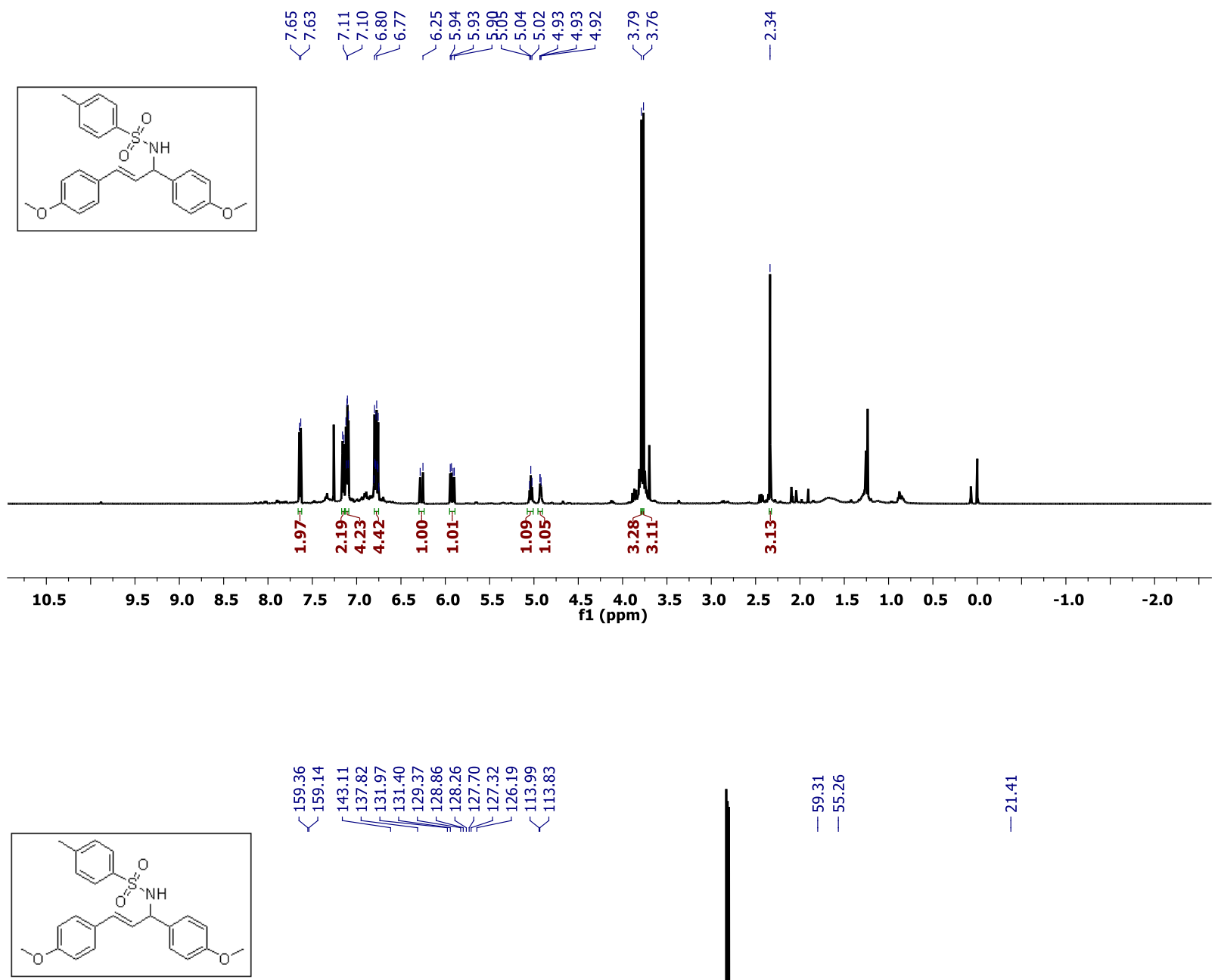

$\vec{m} \stackrel{0}{0}$

ตั่ เูก

$\underset{\vec{j}}{\stackrel{\vec{j}}{i}}$

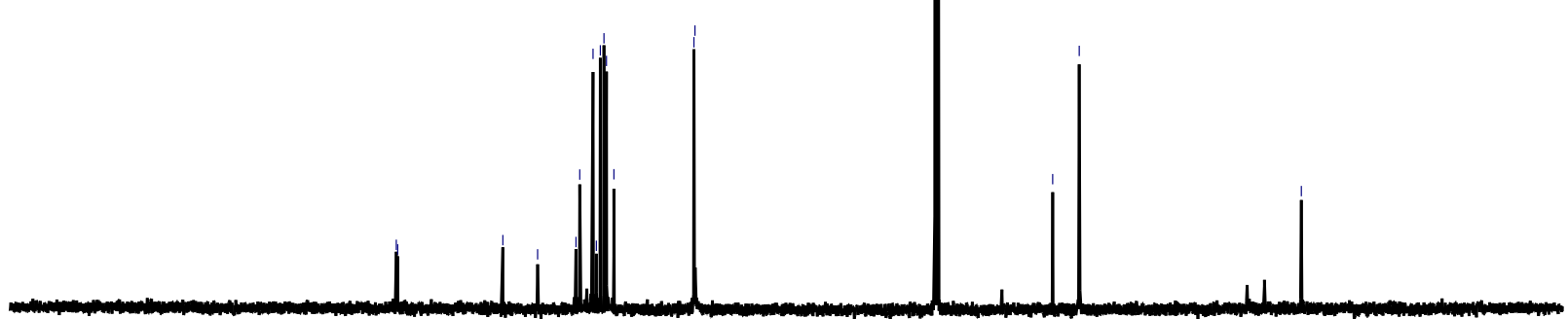

$\begin{array}{lllllllllllllllllllllllll}210 & 200 & 190 & 180 & 170 & 160 & 150 & 140 & 130 & 120 & 110 & \begin{array}{l}100 \\ \mathrm{f} 1\end{array}(\mathrm{ppm}) & 90 & 80 & 70 & 60 & 50 & 40 & 30 & 20 & 10 & 0 & -10\end{array}$ 
DEPT spectra of compound $3 \mathrm{ba:}$

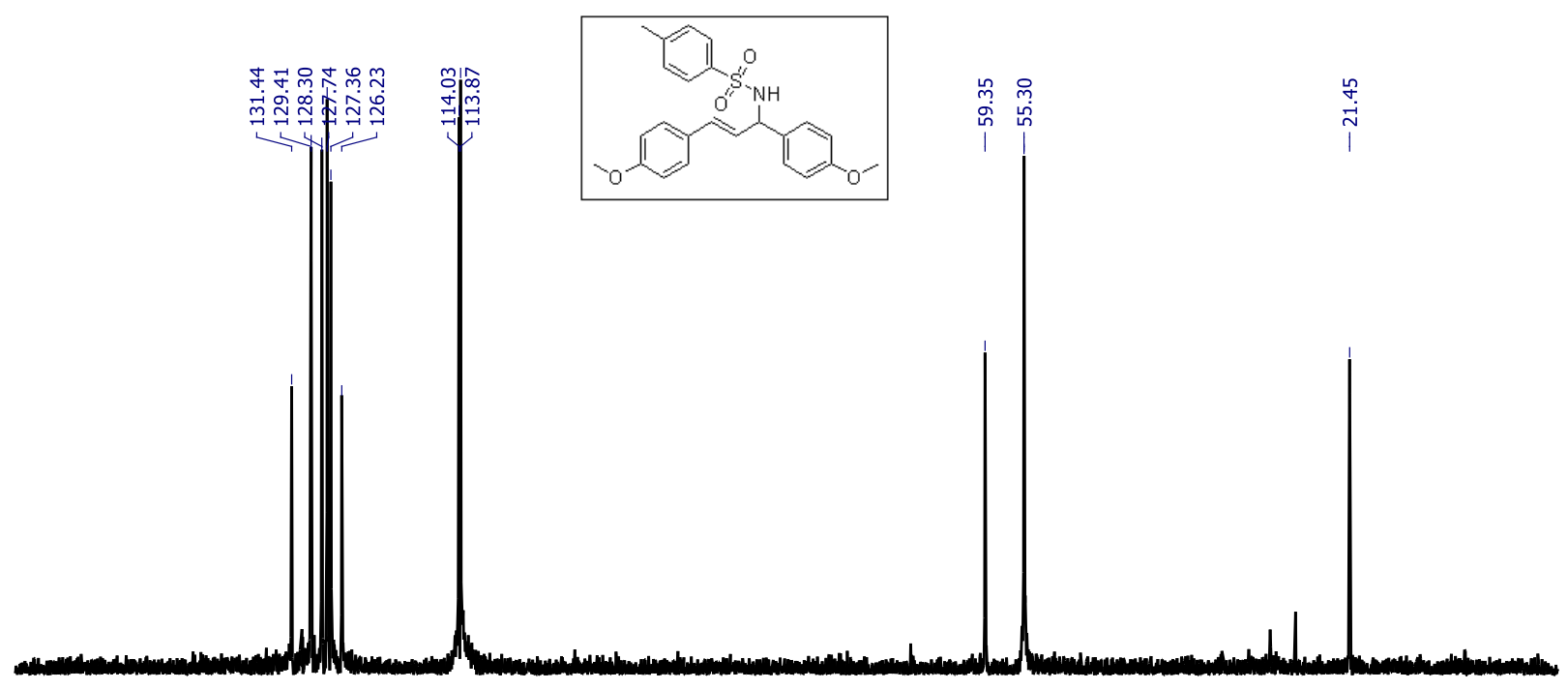

160 $150 \quad 140$ 130 120 $110 \quad 100$ $90 \quad \begin{gathered}80 \\ f 1(\mathrm{ppm})\end{gathered}$
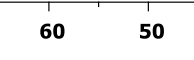

40

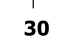

$2010 \quad 0$ 
${ }^{1} \mathrm{H}$ and ${ }^{13} \mathrm{C}$ spectra of compound $3 \mathrm{ca}$ :
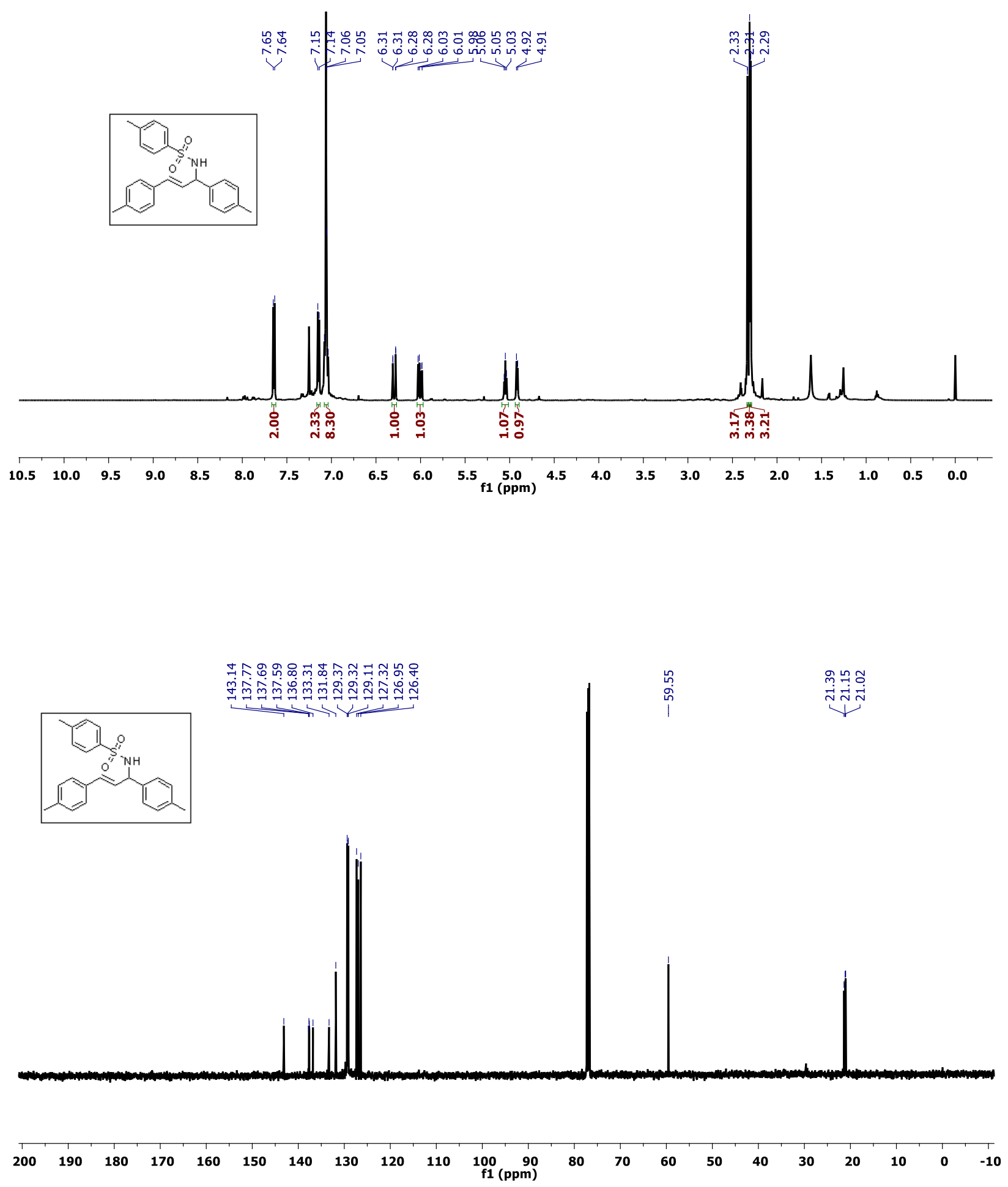
DEPT spectra of compound 3ca:

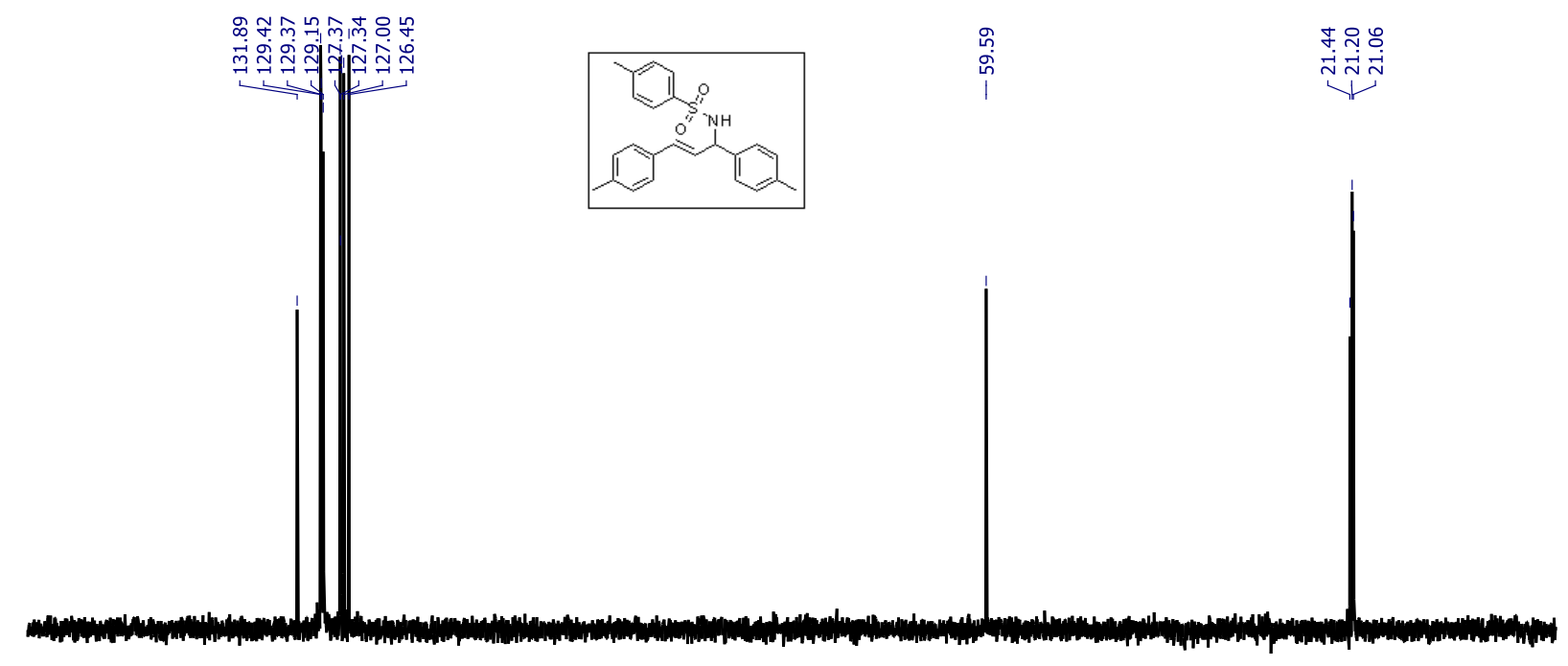

160

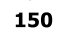

140

130

120

$110 \quad 100$

90 f1 $\stackrel{80}{(\mathrm{ppm})}$

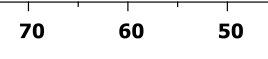

40

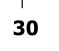

$20 \quad 10 \quad 0$ 
${ }^{1} \mathrm{H}$ and ${ }^{13} \mathrm{C}$ spectra of compound 3da:

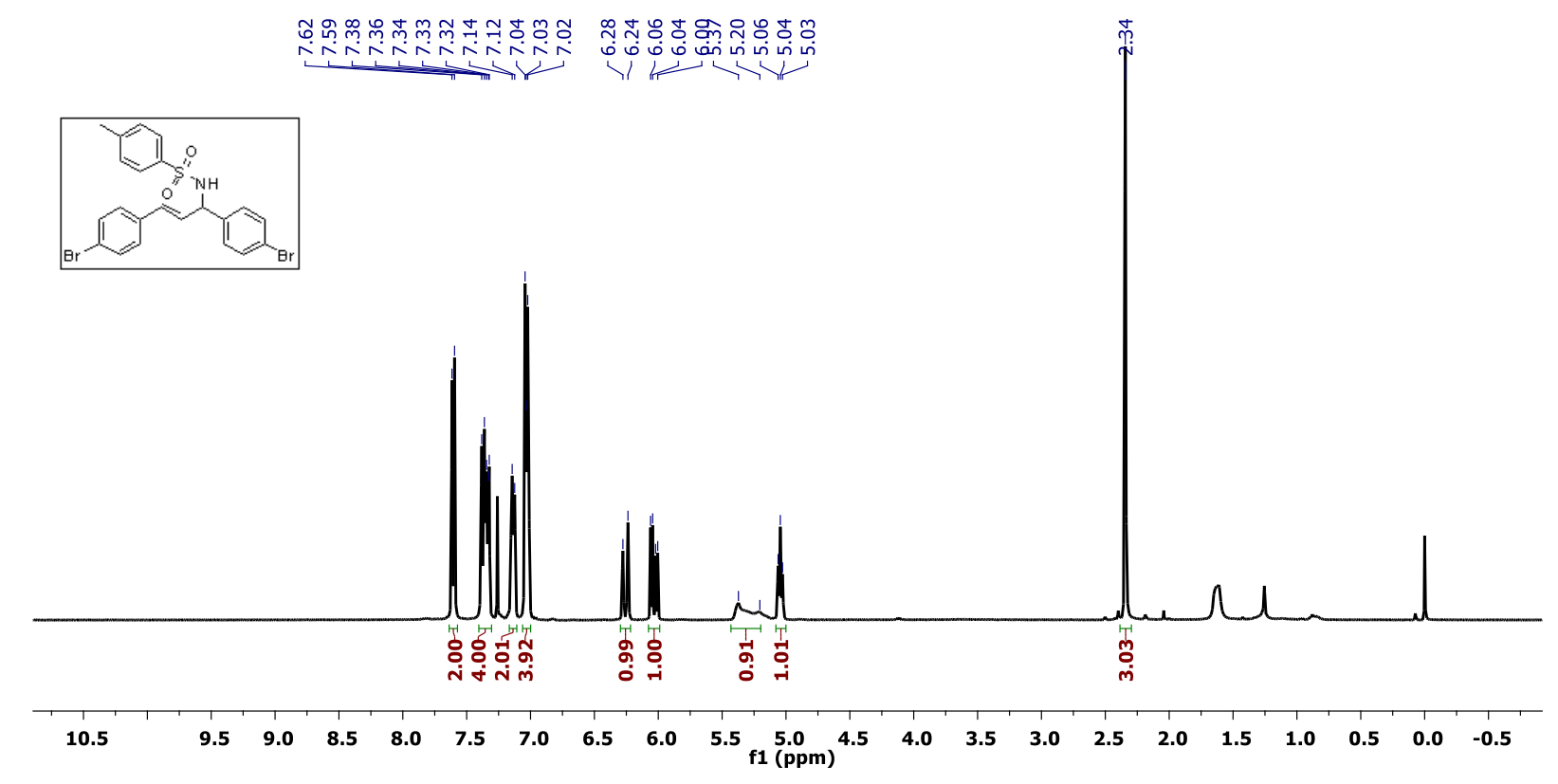

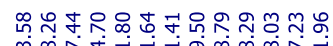

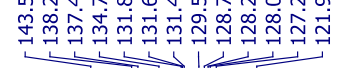
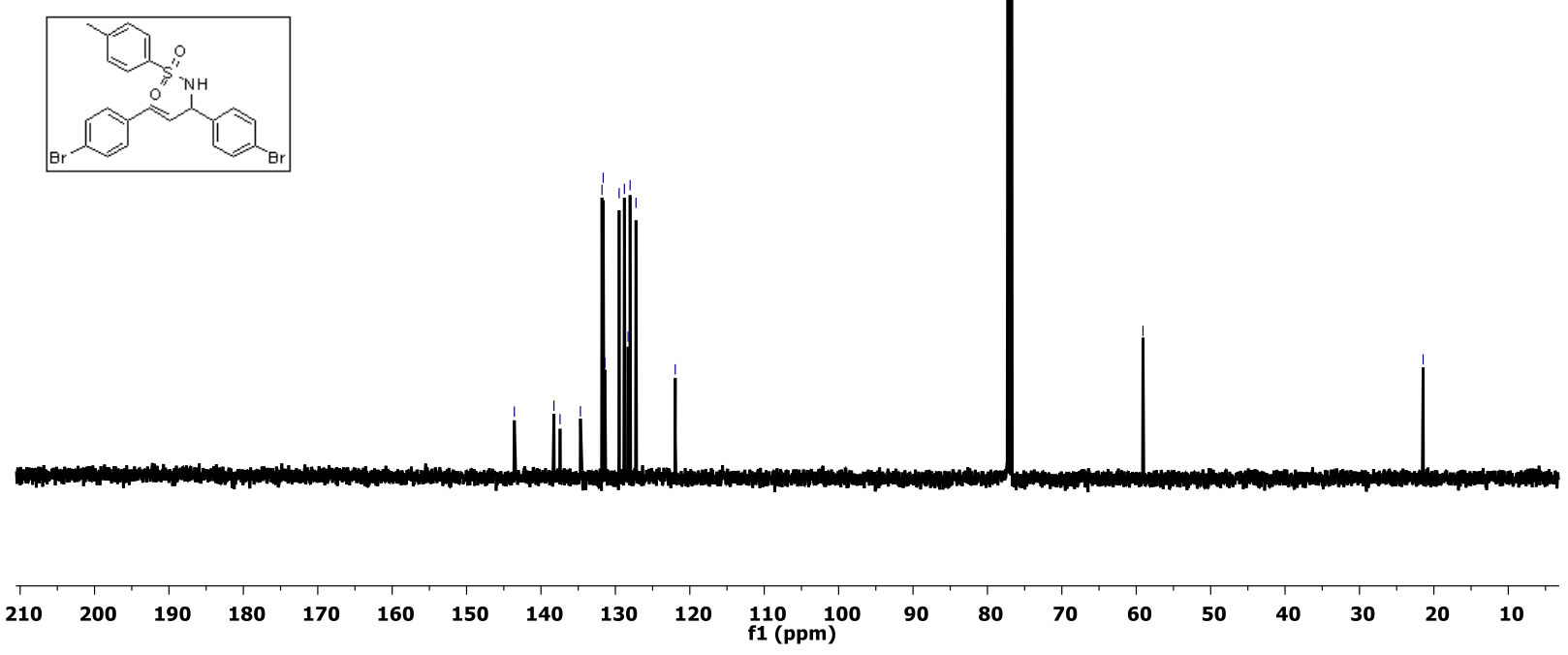
DEPT spectra of compound 3da:

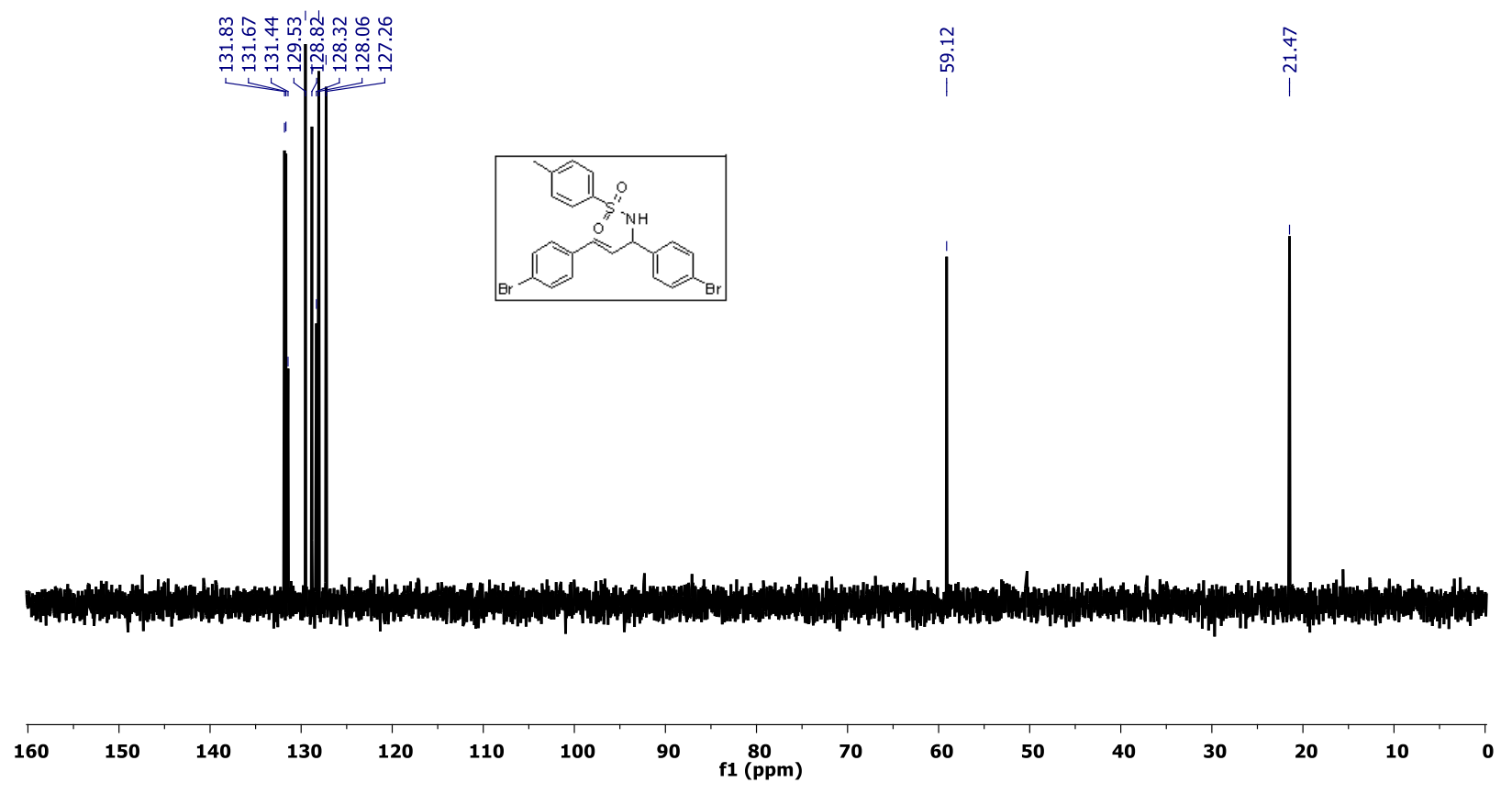


${ }^{1} \mathrm{H}$ and ${ }^{13} \mathrm{C}$ spectra of compound 3ea:
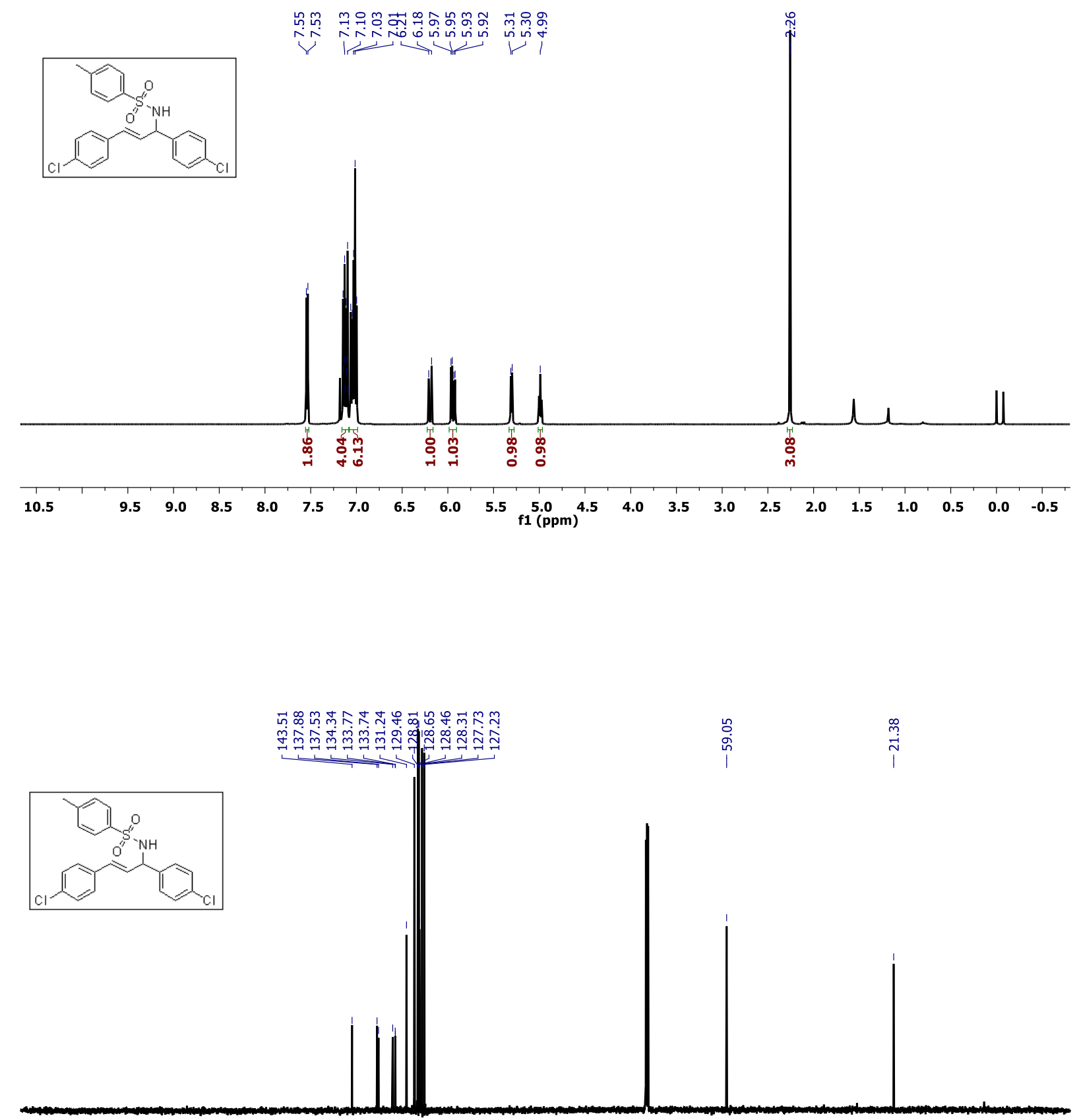
DEPT spectra of compound 3ea:
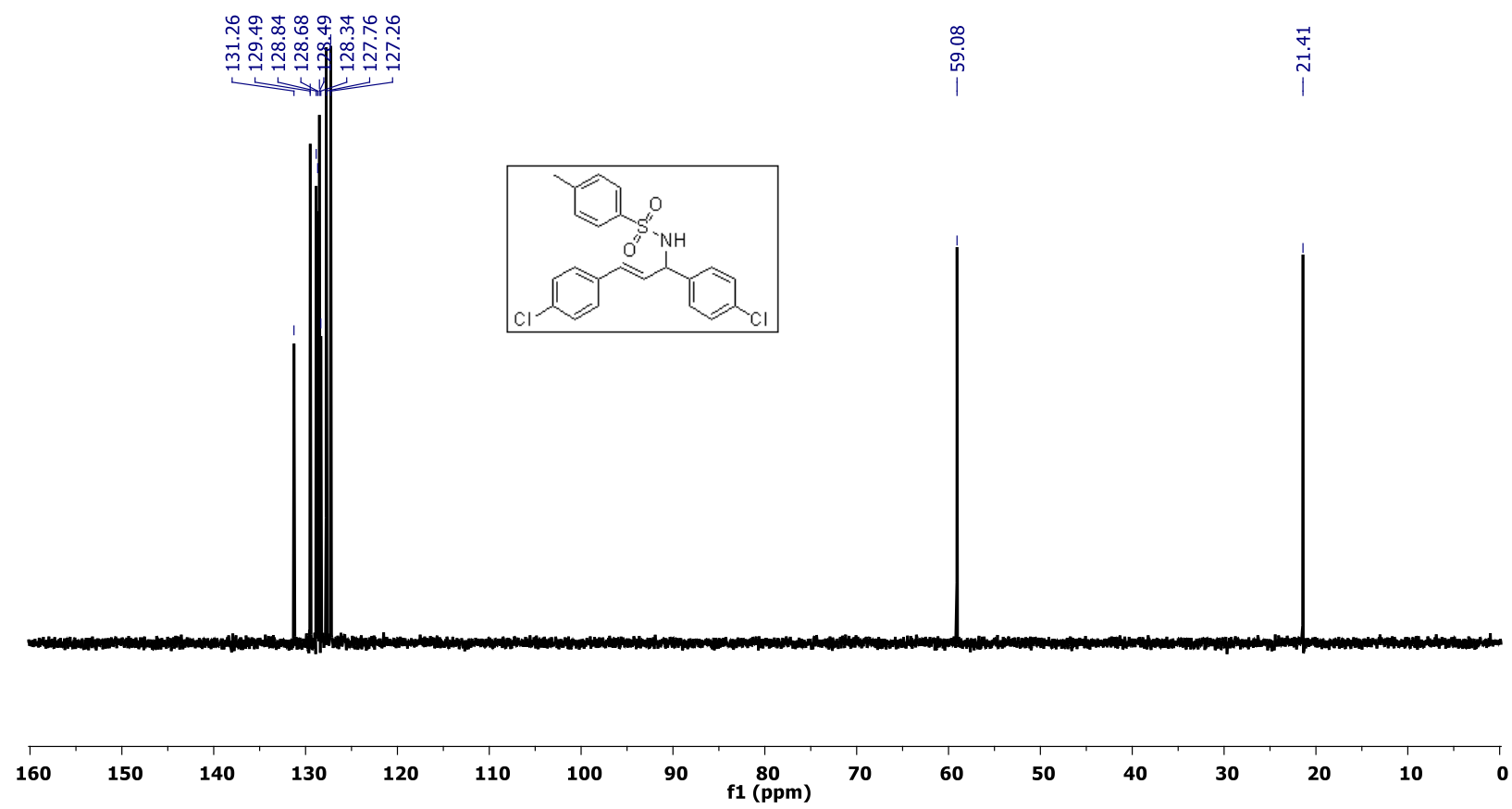
${ }^{1} \mathrm{H}$ and ${ }^{13} \mathrm{C}$ spectra of compound 3 fa:
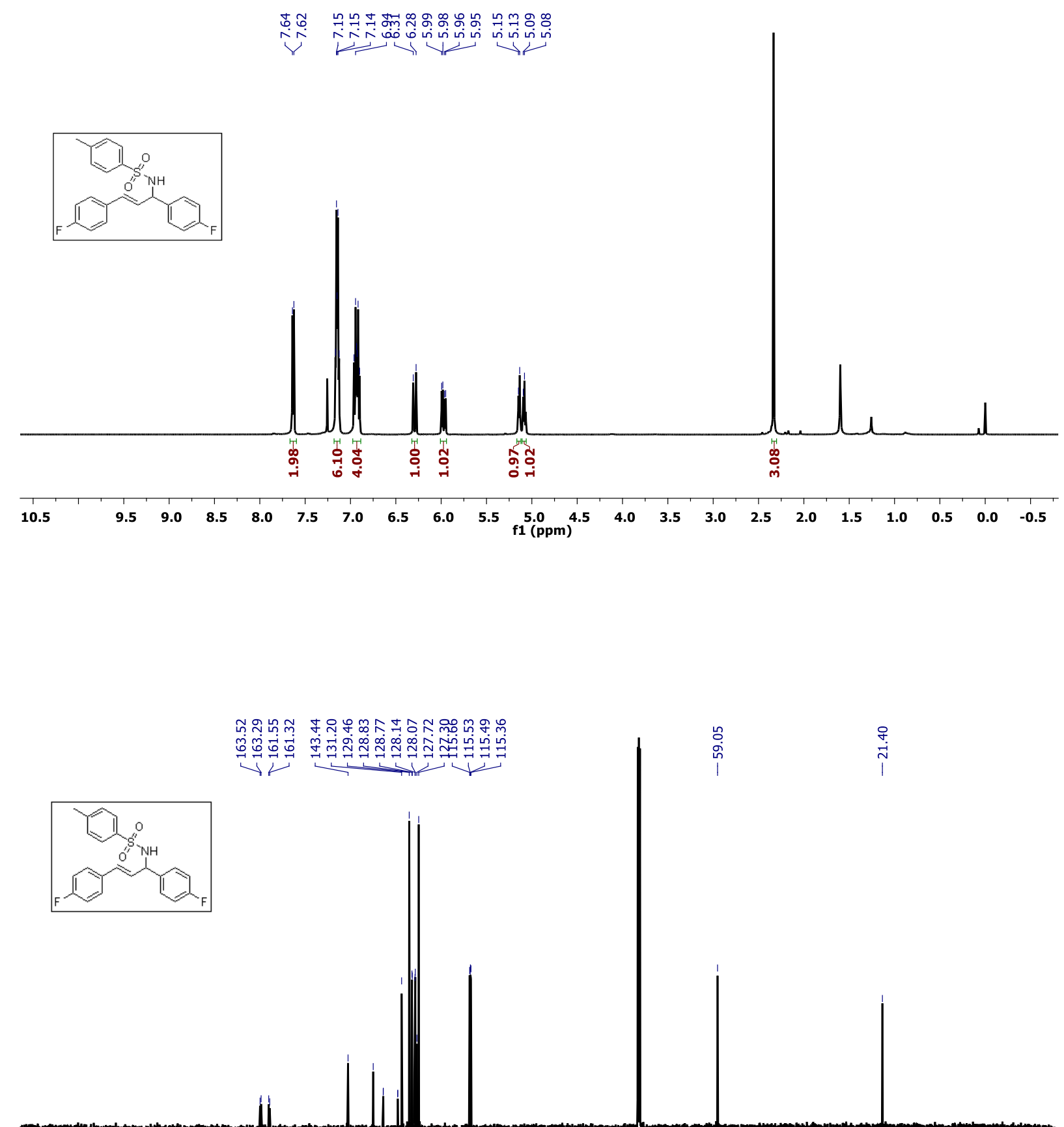

$\begin{array}{lllllllllllllllllllllllllll}210 & 200 & 190 & 180 & 170 & 160 & 150 & 140 & 130 & 120 & 110 & 100 & 90 & 80 & 70 & 60 & 50 & 40 & 30 & 20 & 10 & 0 & -10\end{array}$ 
DEPT spectra of compound 3fa:

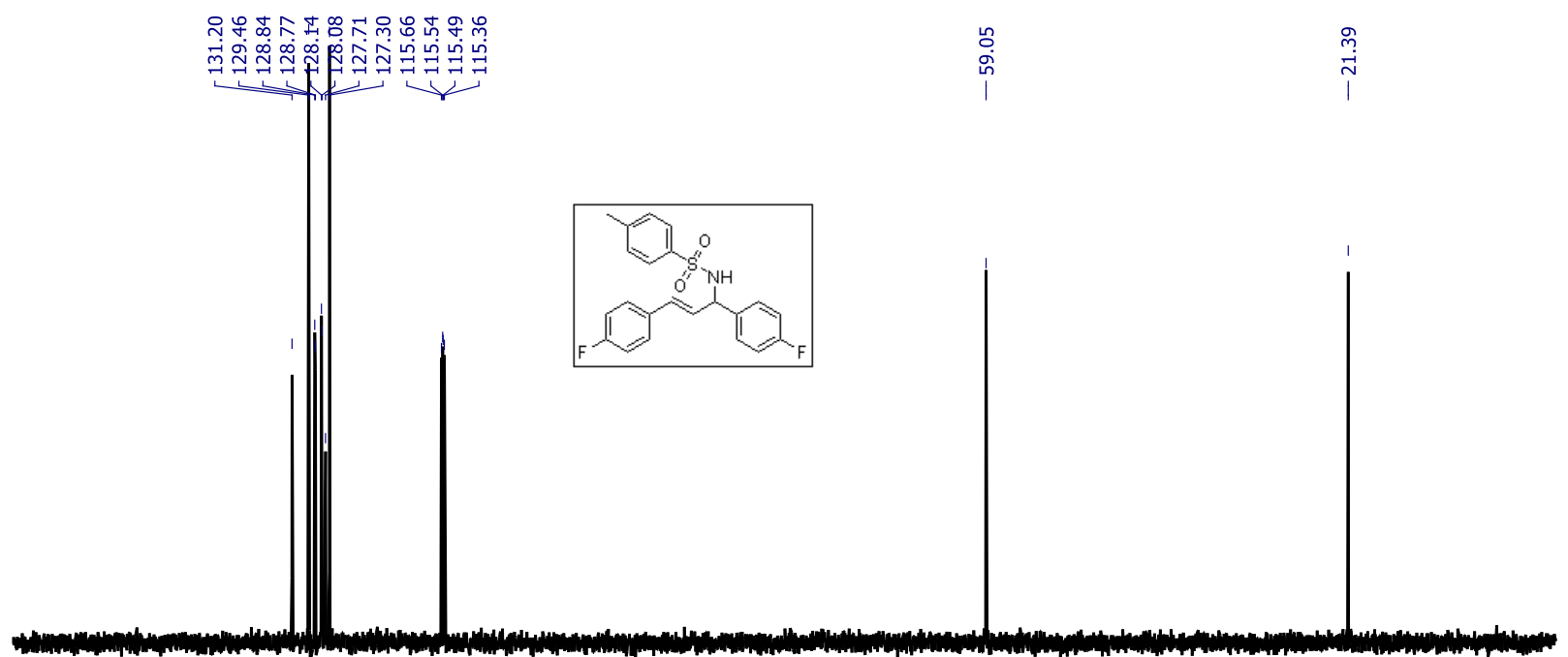

\begin{tabular}{rrrrrrrrrrrrrrrrr}
\hline 160 & 150 & 140 & 130 & 120 & 110 & 100 & 90 & $\underset{f 1}{80}$ & 70 & 60 & 50 & 40 & 30 & 20 & 10 & 0
\end{tabular}

${ }^{19}$ F spectra of compound 3fa:
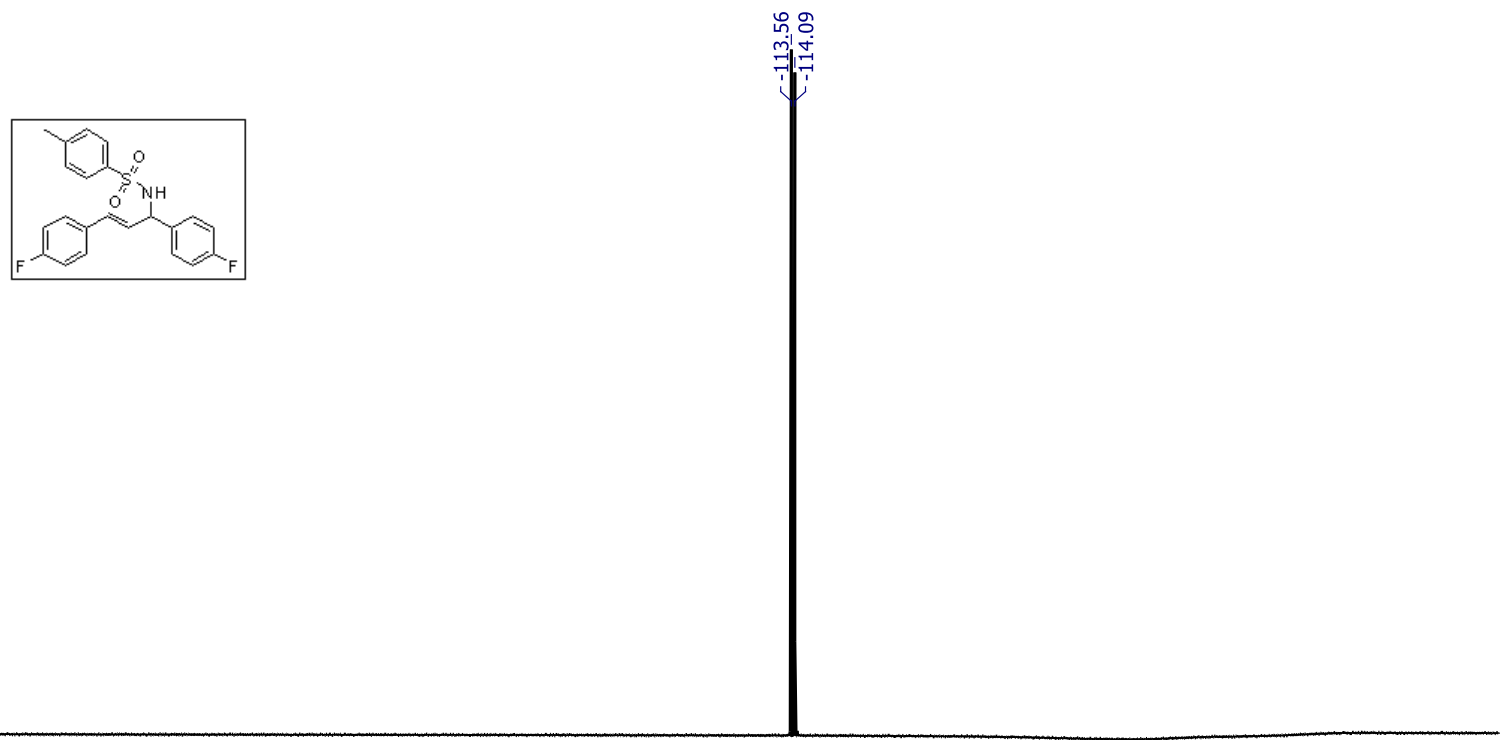

20

$\begin{array}{lllll}10 & 0 & -10 & -20 & -30\end{array}$

$\begin{array}{lllll}-40 & -50 & -60 & -70 & -80\end{array}$

$-90 \mathrm{f1}(\mathrm{ppm})^{-110}$

$-130$

$-150$

$-170$

$-190$

$-210$ 
${ }^{1} \mathrm{H}$ and ${ }^{13} \mathrm{C}$ spectra of compound 3ga:
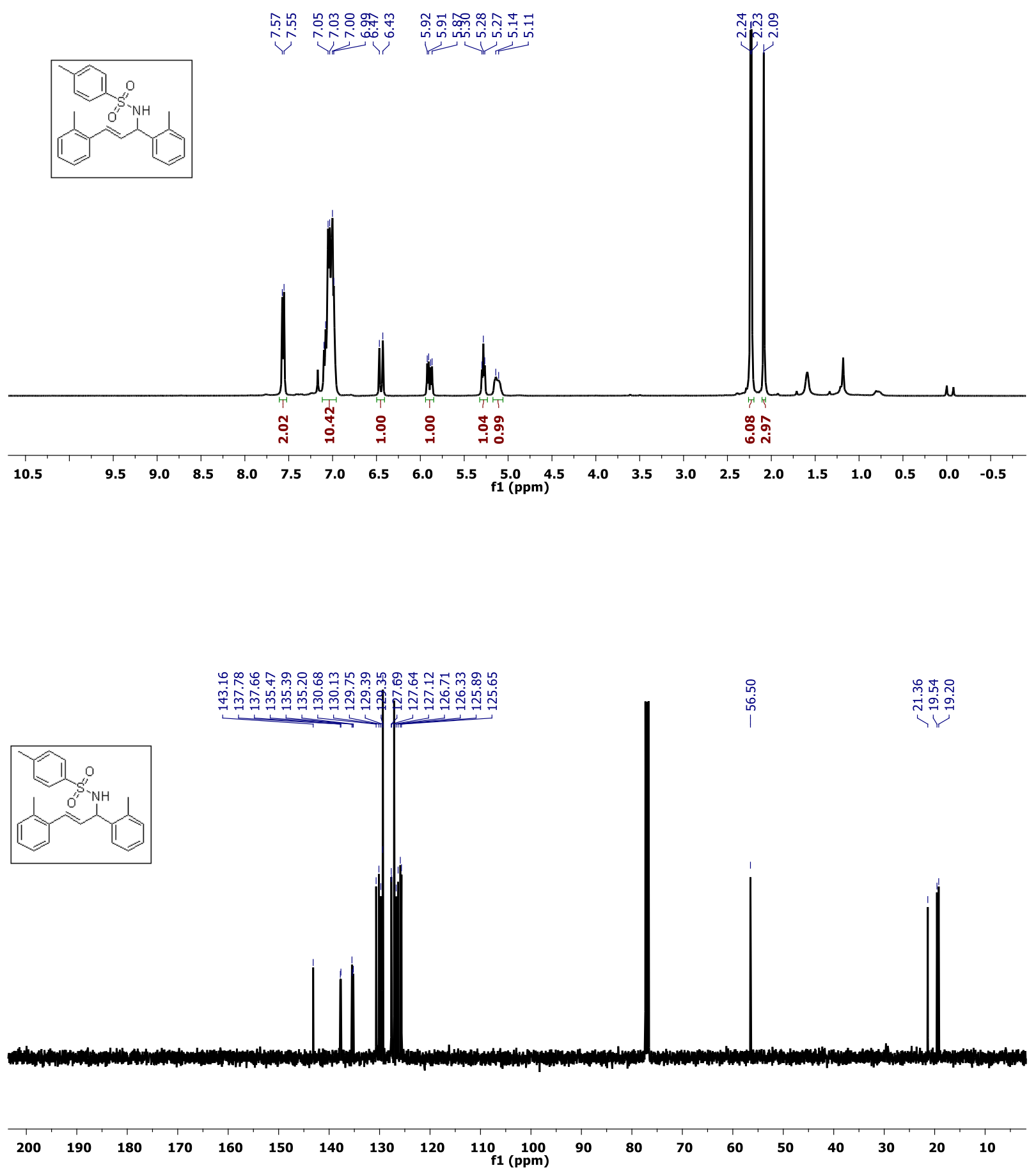
DEPT spectra of compound 3ga:

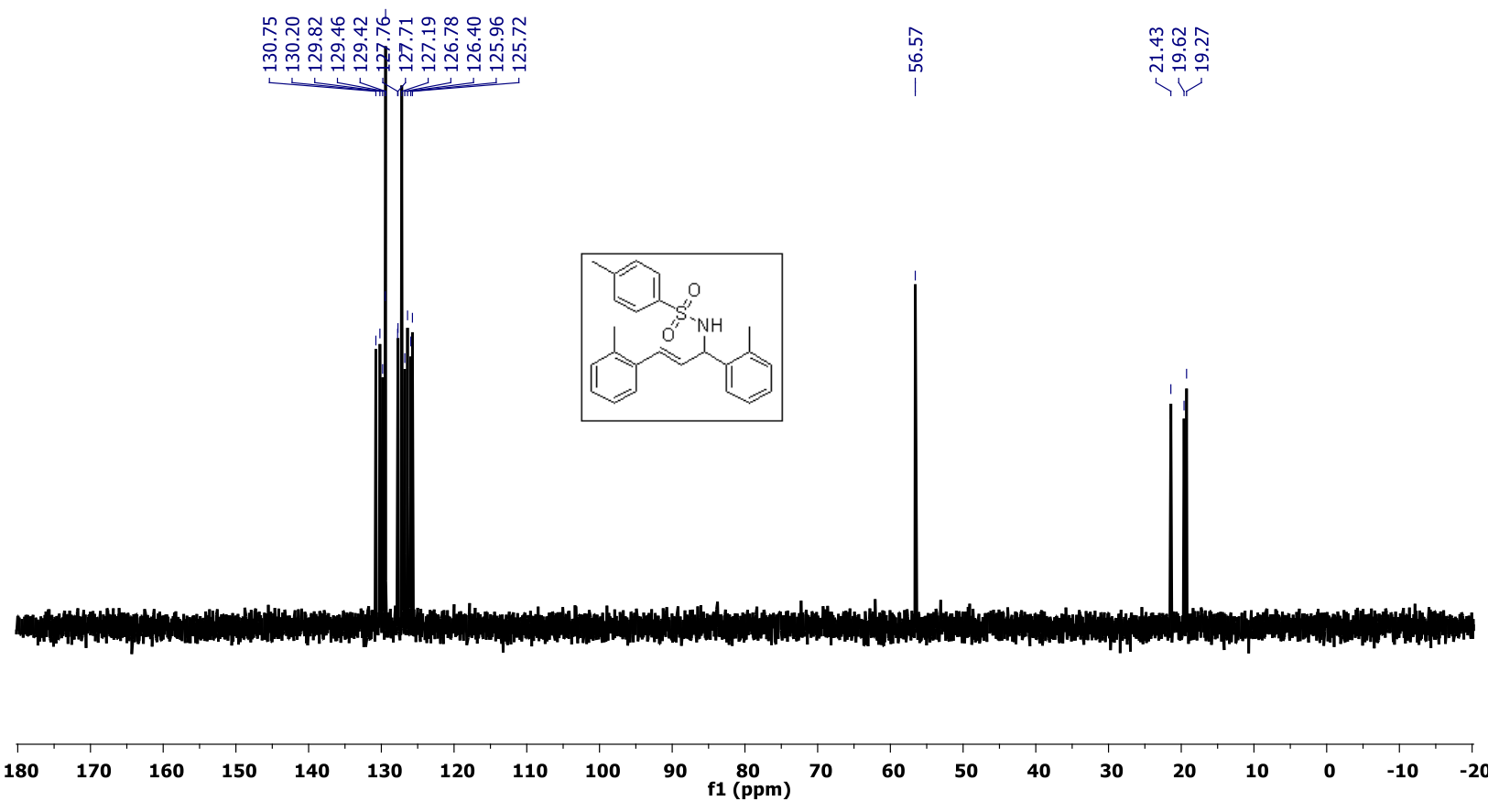


${ }^{1} \mathrm{H}$ and ${ }^{13} \mathrm{C}$ spectra of compound 3ha and 3ha':
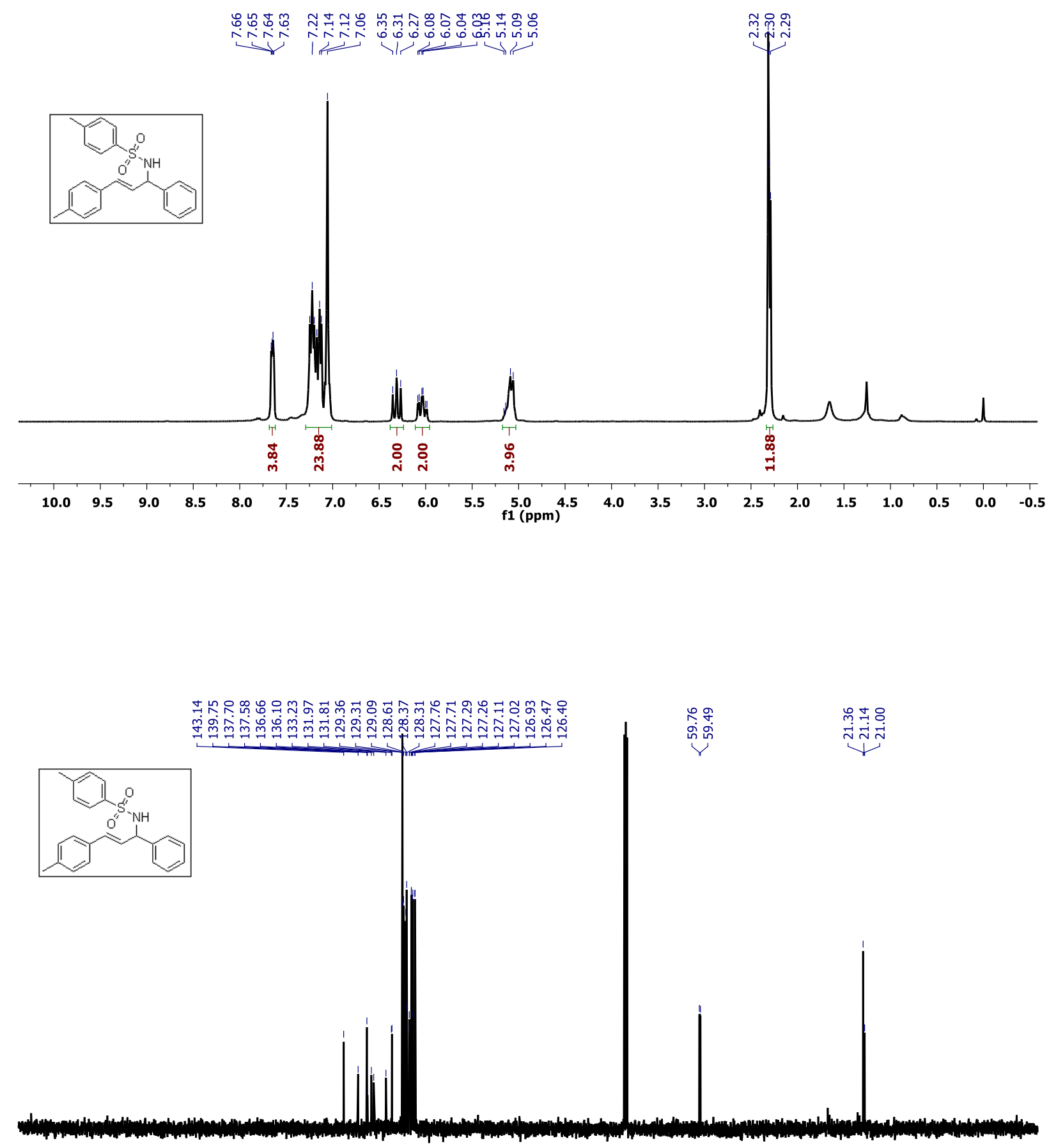

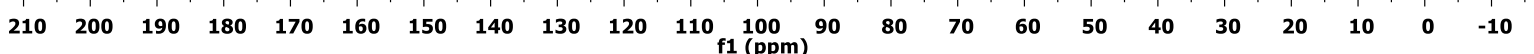


DEPT spectra of compound 3ha and 3ha':

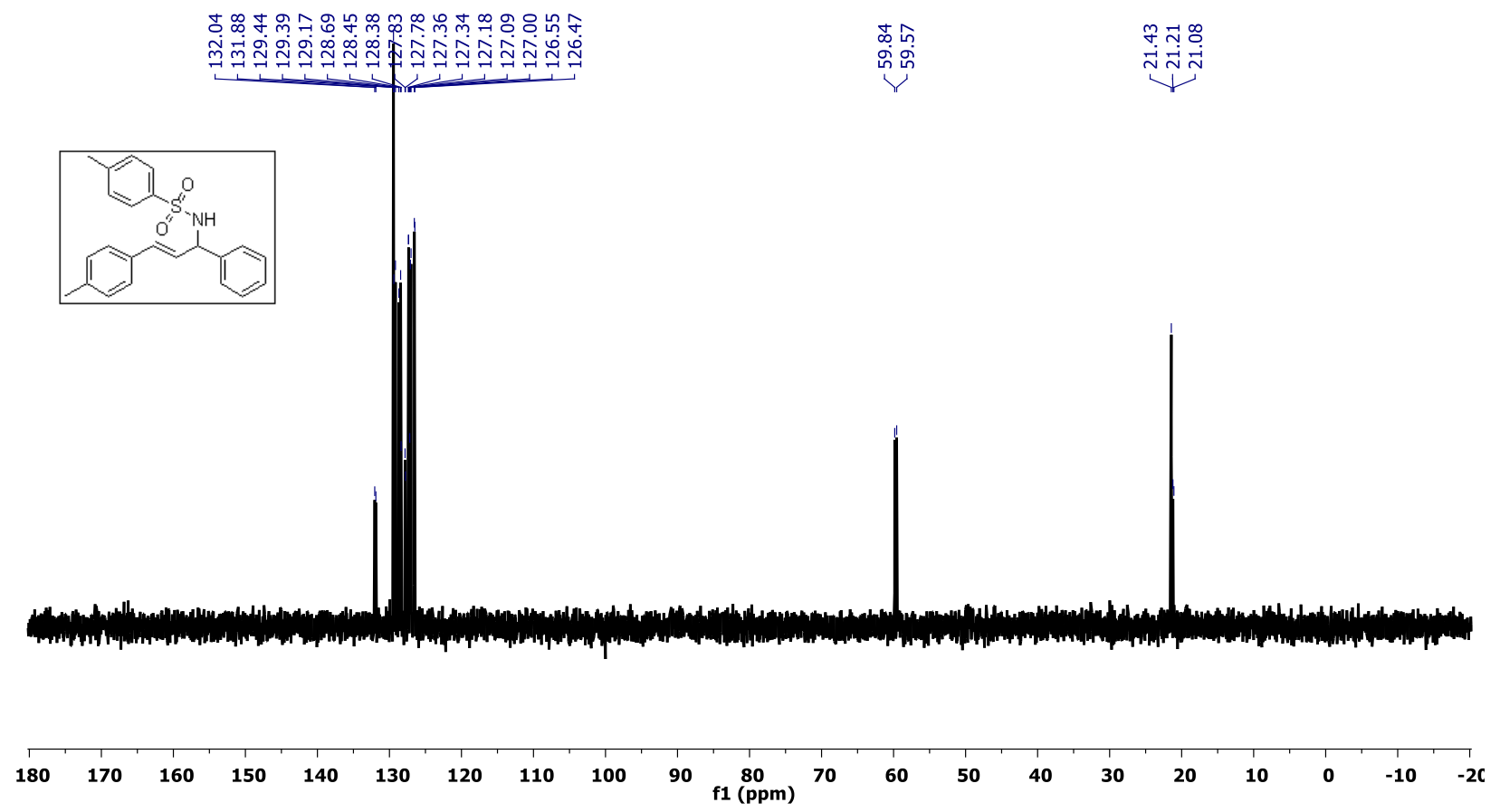


${ }^{1} \mathrm{H}$ and ${ }^{13} \mathrm{C}$ spectra of compound 3ia and 3ia':

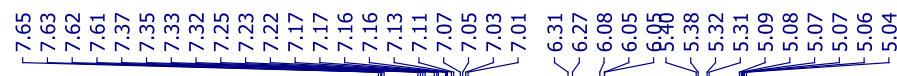
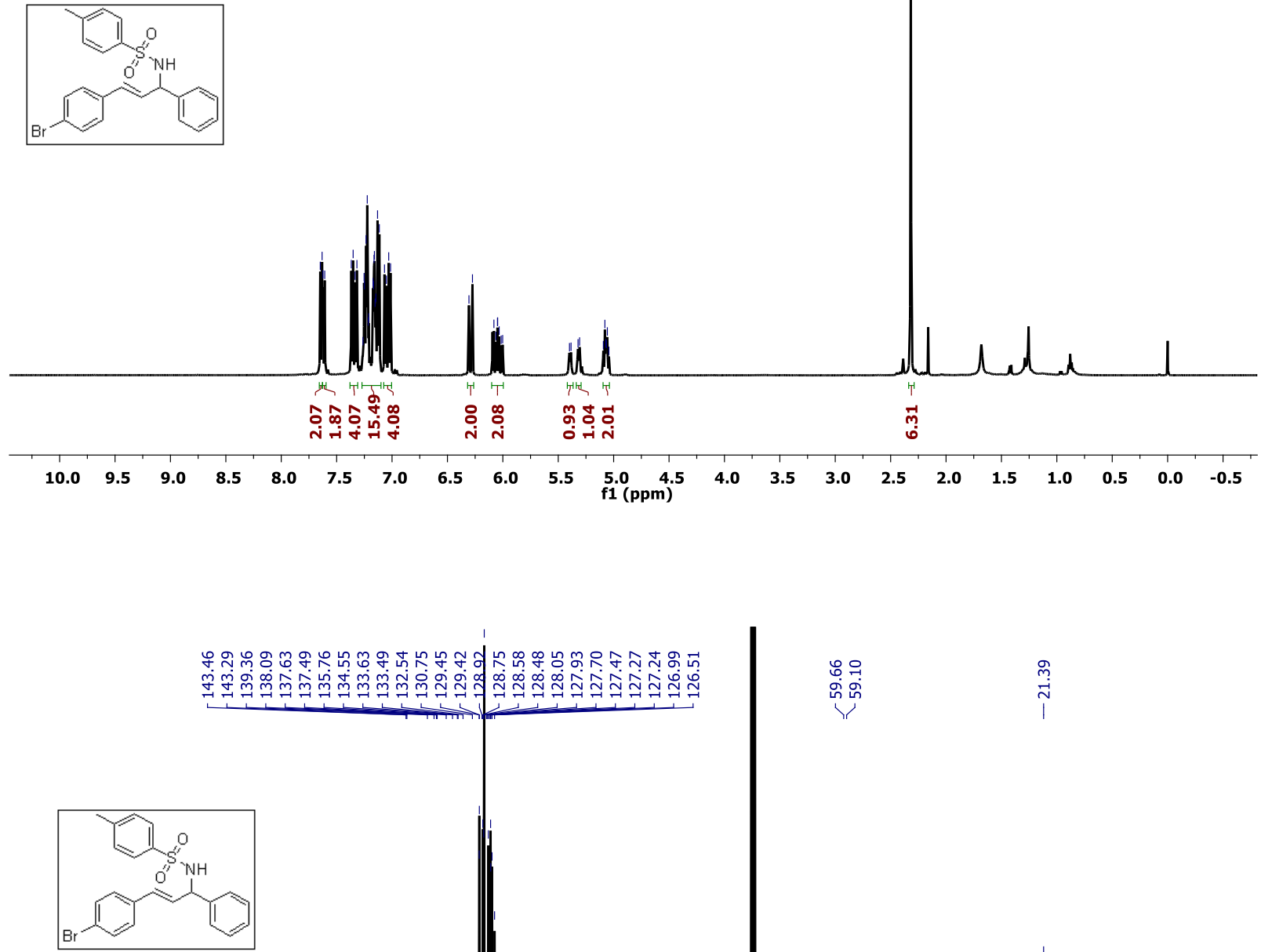

$\begin{array}{llllllllllll}210 & 200 & 190 & 180 & 170 & 160 & 150 & 140 & 130 & 120 & 110 & \begin{array}{l}100 \\ \text { f1 (ppm) }\end{array}\end{array}$ 
DEPT spectra of compound 3ia and 3ia':

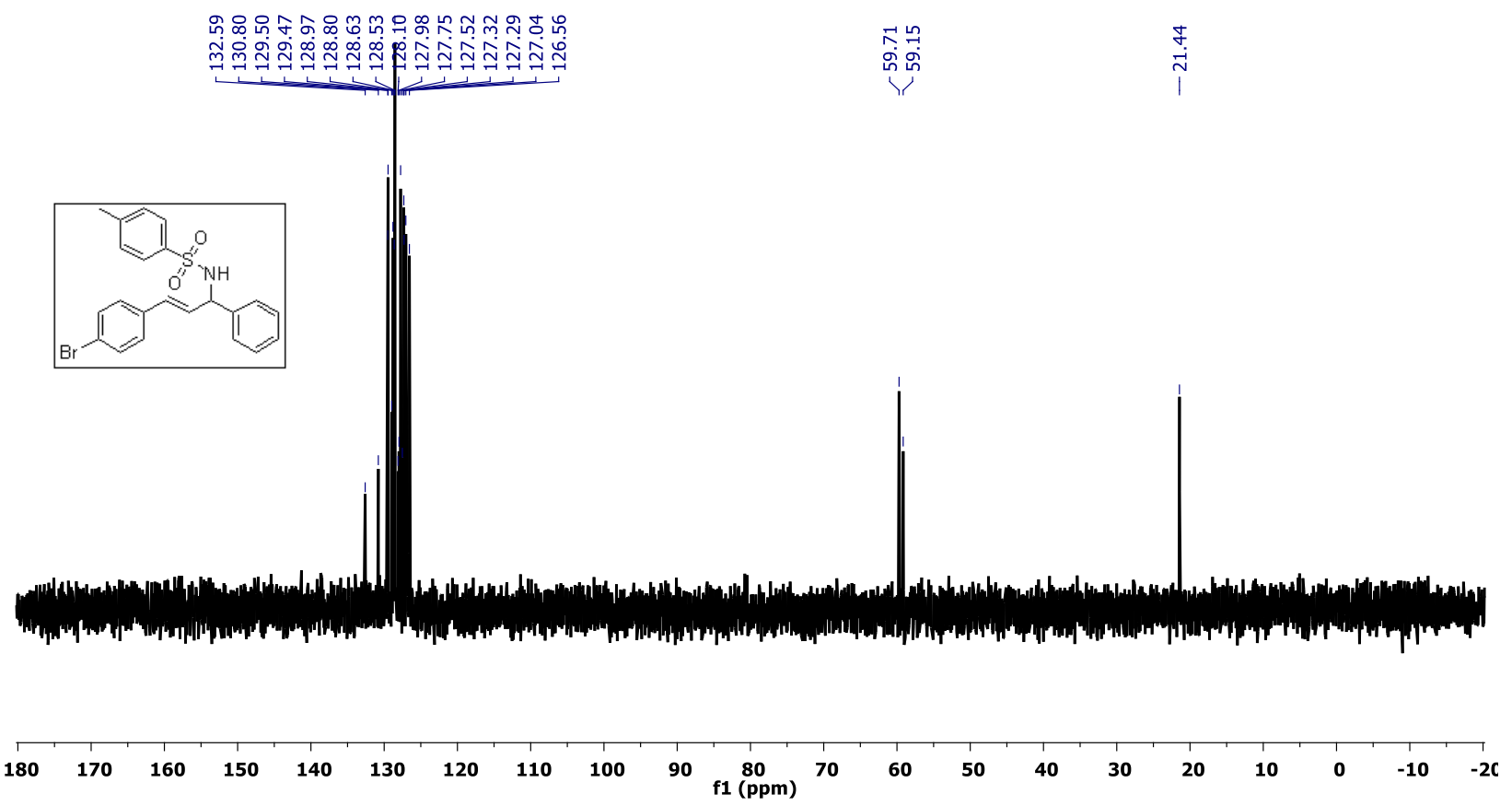


${ }^{1} \mathrm{H}$ and ${ }^{13} \mathrm{C}$ spectra of compound $3 \mathrm{ja}$ and $3 \mathrm{ja}$ ':
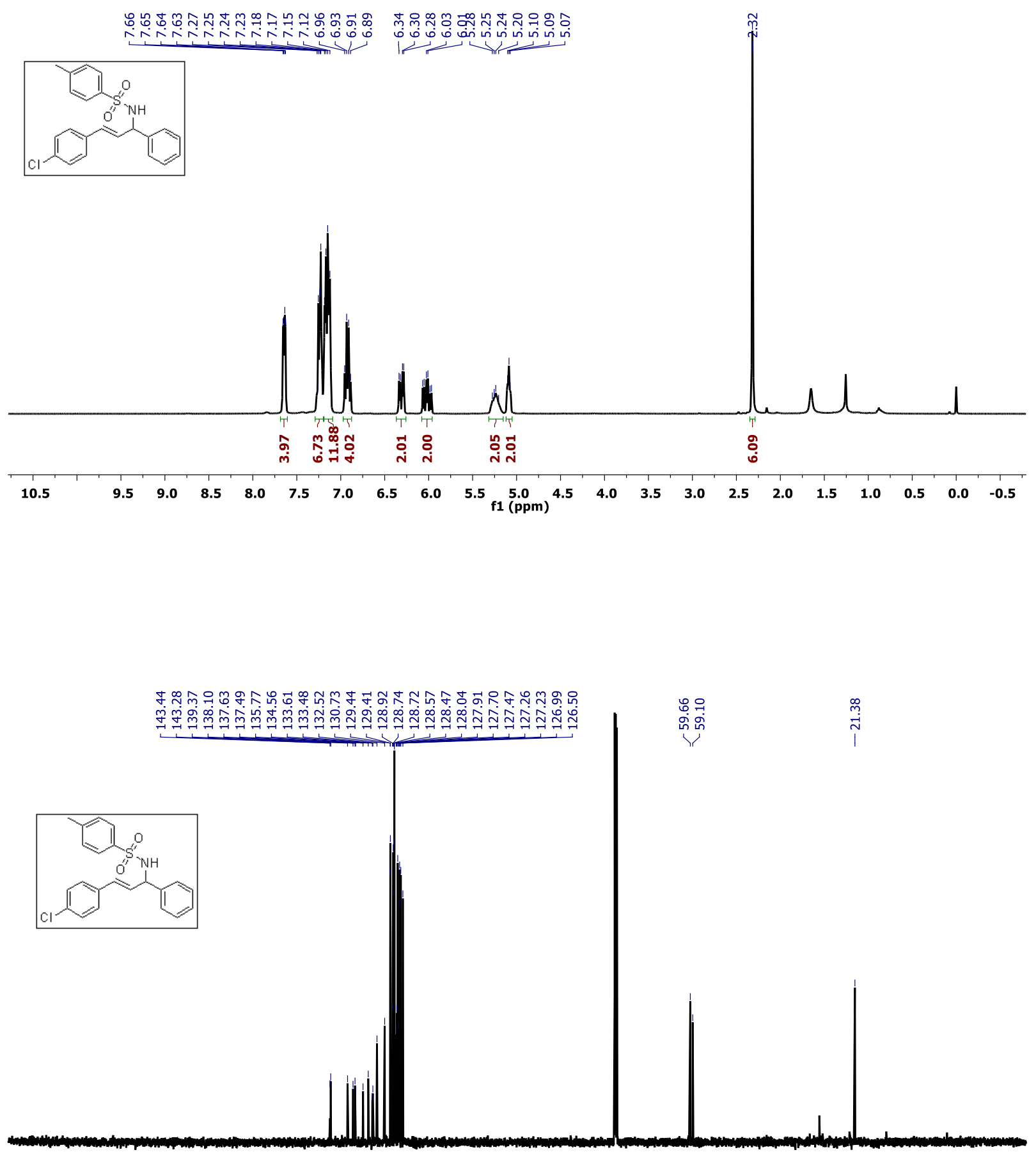

$\begin{array}{lllllllllllllllllllllllll}210 & 200 & 190 & 180 & 170 & 160 & 150 & 140 & 130 & 120 & 110 & \underset{f 1}{100}(\mathrm{ppm}) & 90 & 80 & 70 & 60 & 50 & 40 & 30 & 20 & 10 & 0 & -10\end{array}$ 
DEPT spectra of compound $3 \mathbf{j a}$ and $3 \mathbf{j a} a$ ':

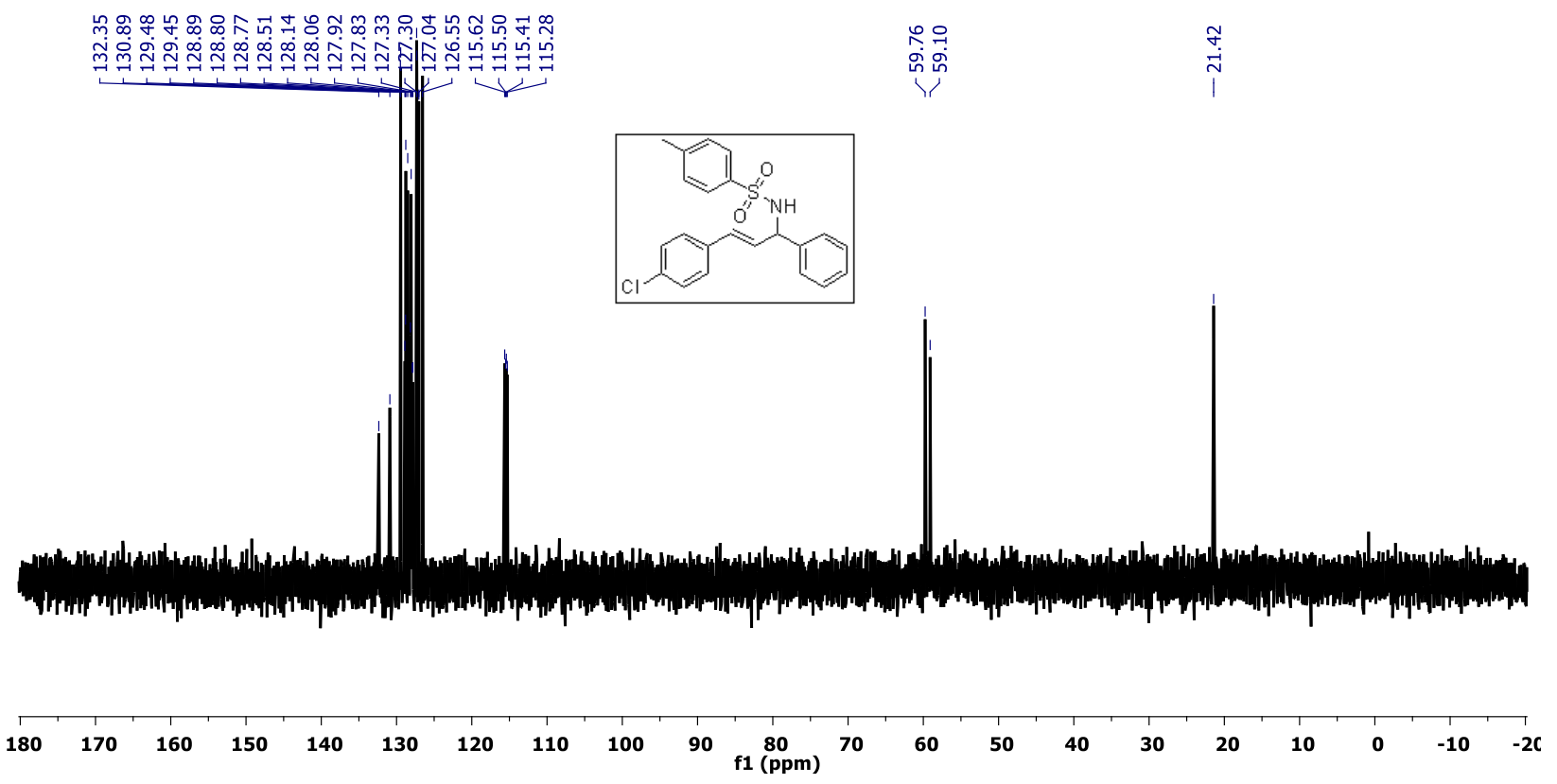


${ }^{1} \mathrm{H}$ and ${ }^{13} \mathrm{C}$ spectra of compound $3 \mathrm{ka}$ and $3 \mathrm{ka}$ ':

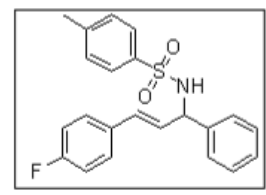

诲
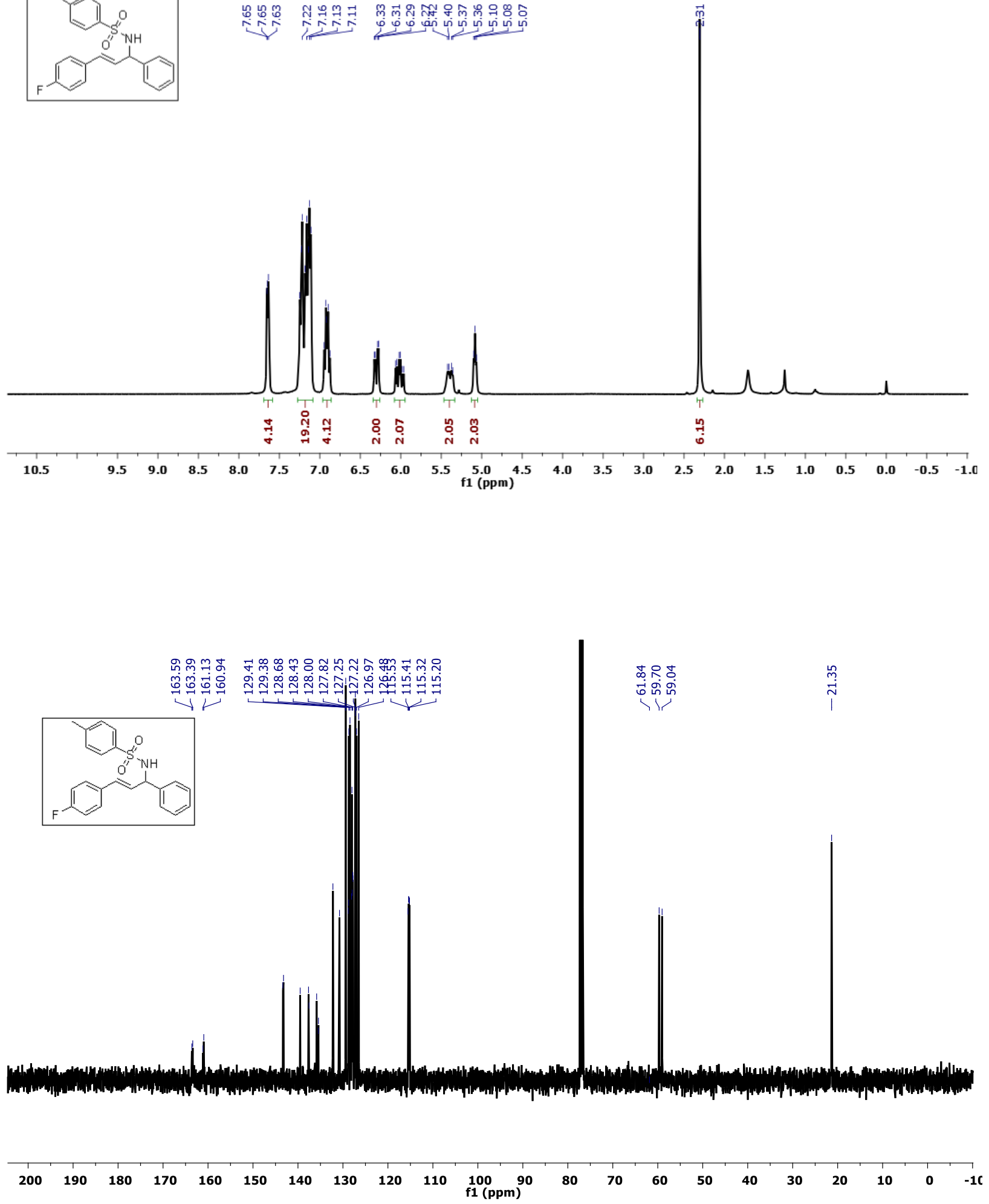
DEPT spectra of compound 3ka and 3ka':

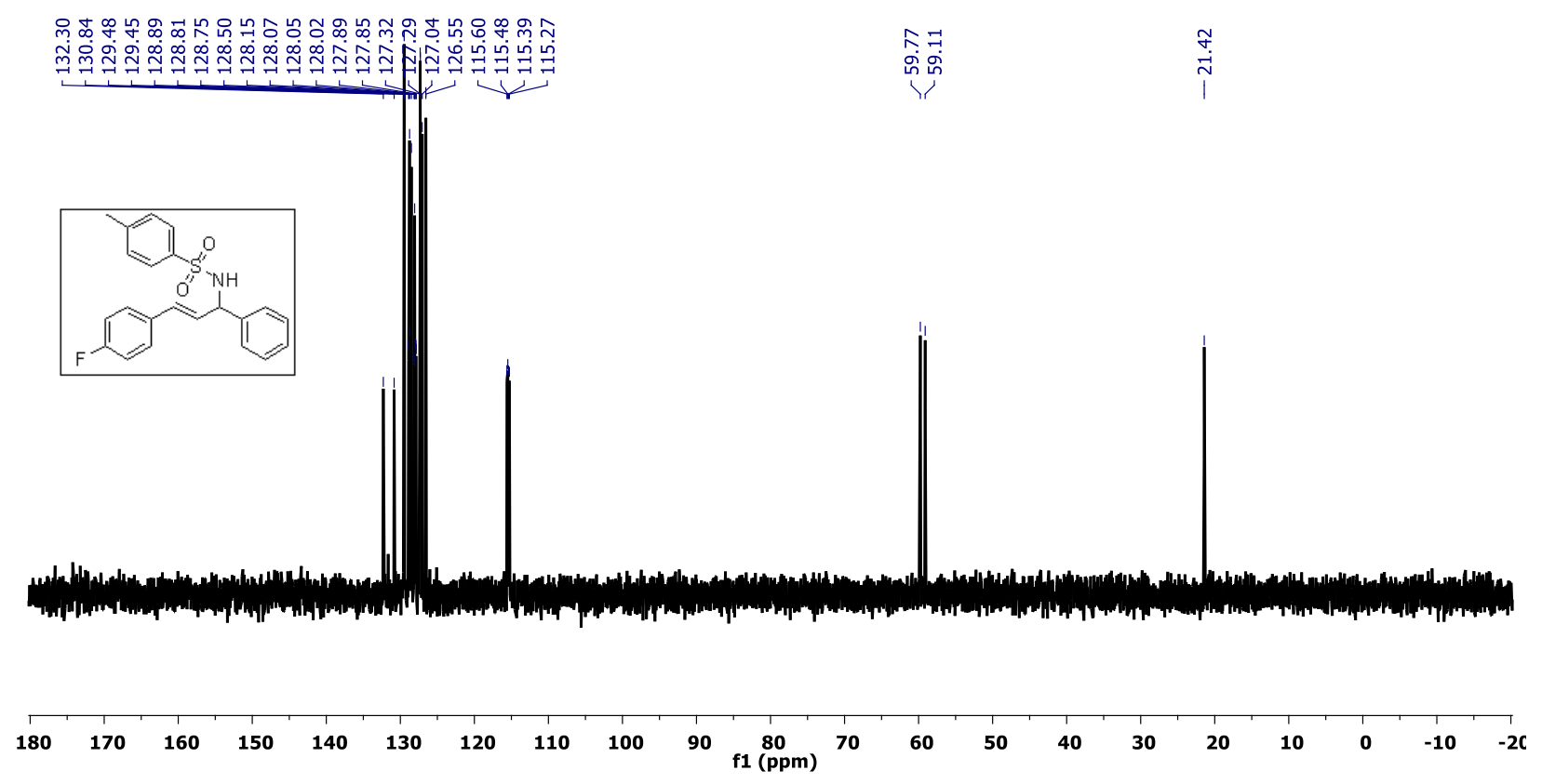

${ }^{19} \mathrm{~F}$ spectra of compound 3ka and 3ka':
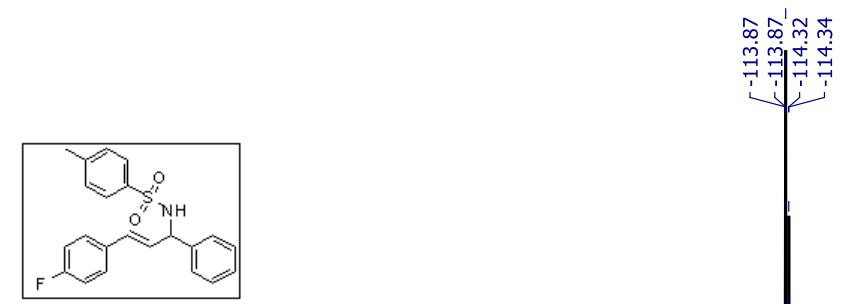

\begin{tabular}{|c|c|c|c|c|c|c|c|c|c|c|c|c|c|c|c|c|c|}
\hline 1 & 1 & 1 & 1 & 1 & 1 & 1 & 1 & 1 & 1 & 1 & 1 & $\begin{array}{llll} & 1 & 1\end{array}$ & 1 & 1 & 1 & 1 & 1 \\
\hline 20 & 10 & 0 & -10 & -20 & -30 & -40 & -50 & -60 & -70 & -80 & $-90 \mathrm{f}$ & $11(p p m)^{-110}$ & -130 & -150 & -170 & -190 & -210 \\
\hline
\end{tabular}




\section{${ }^{1} \mathrm{H}$ and ${ }^{13} \mathrm{C}$ spectra of compound 3la and 3la':}
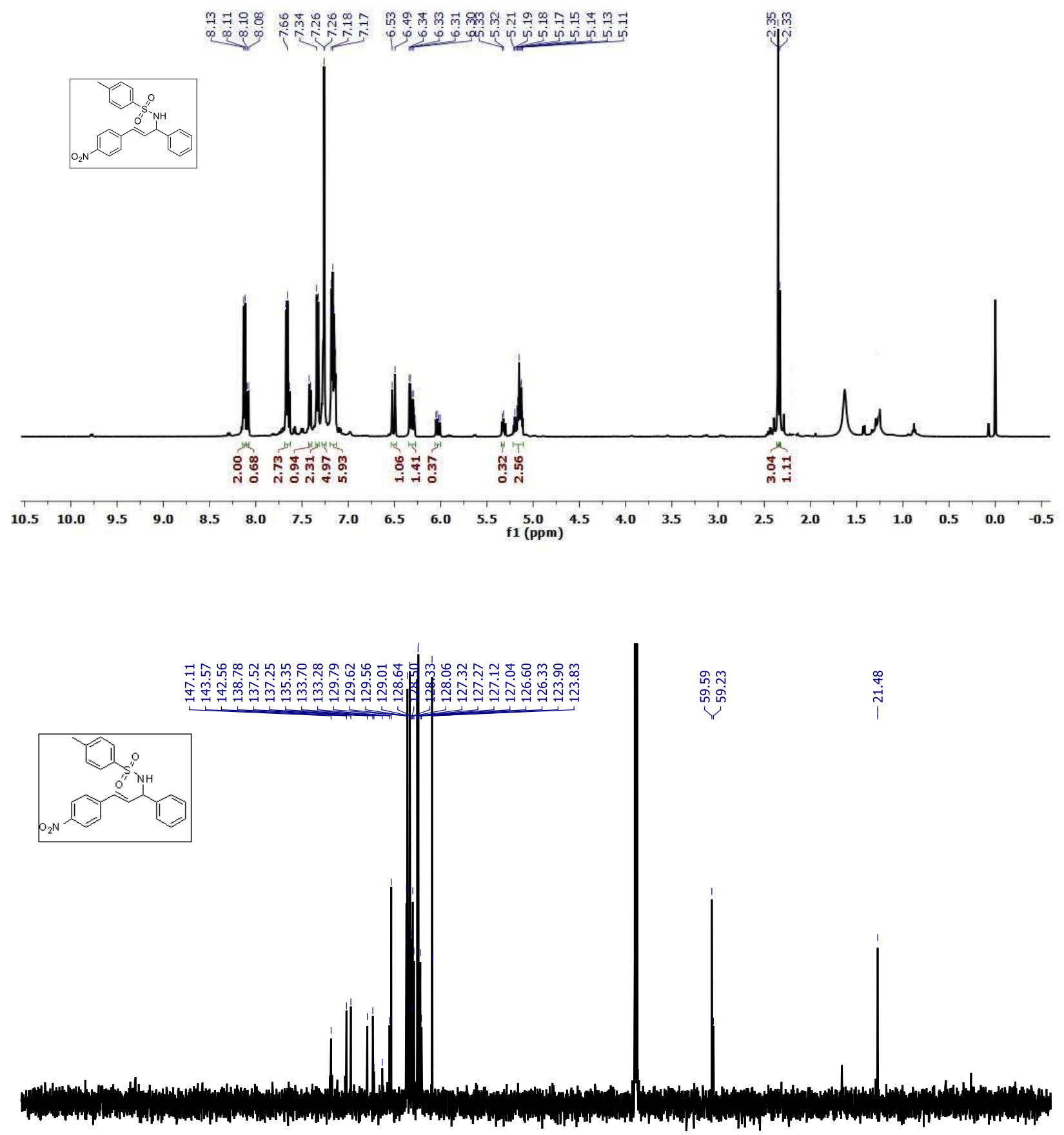

$\begin{array}{llllllllllllllllllllllllll}210 & 200 & 190 & 180 & 170 & 160 & 150 & 140 & 130 & 120 & 110 & 100 & 100 & 80 & 70 & 60 & 50 & 40 & 30 & 20 & 10 & 0 & -10\end{array}$ 
DEPT spectra of compound 3la and 3la':
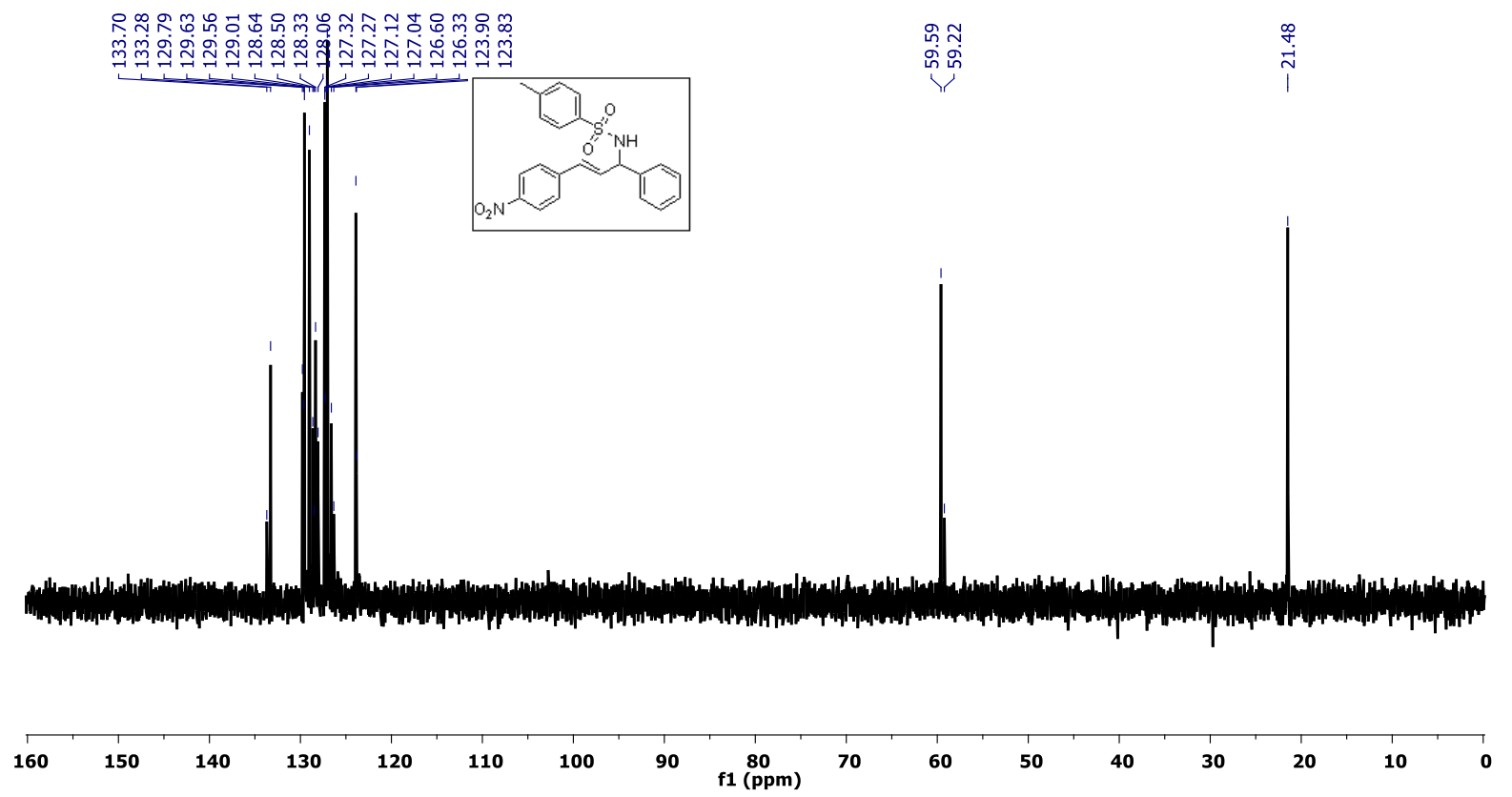

HMQC NMR of 3la:

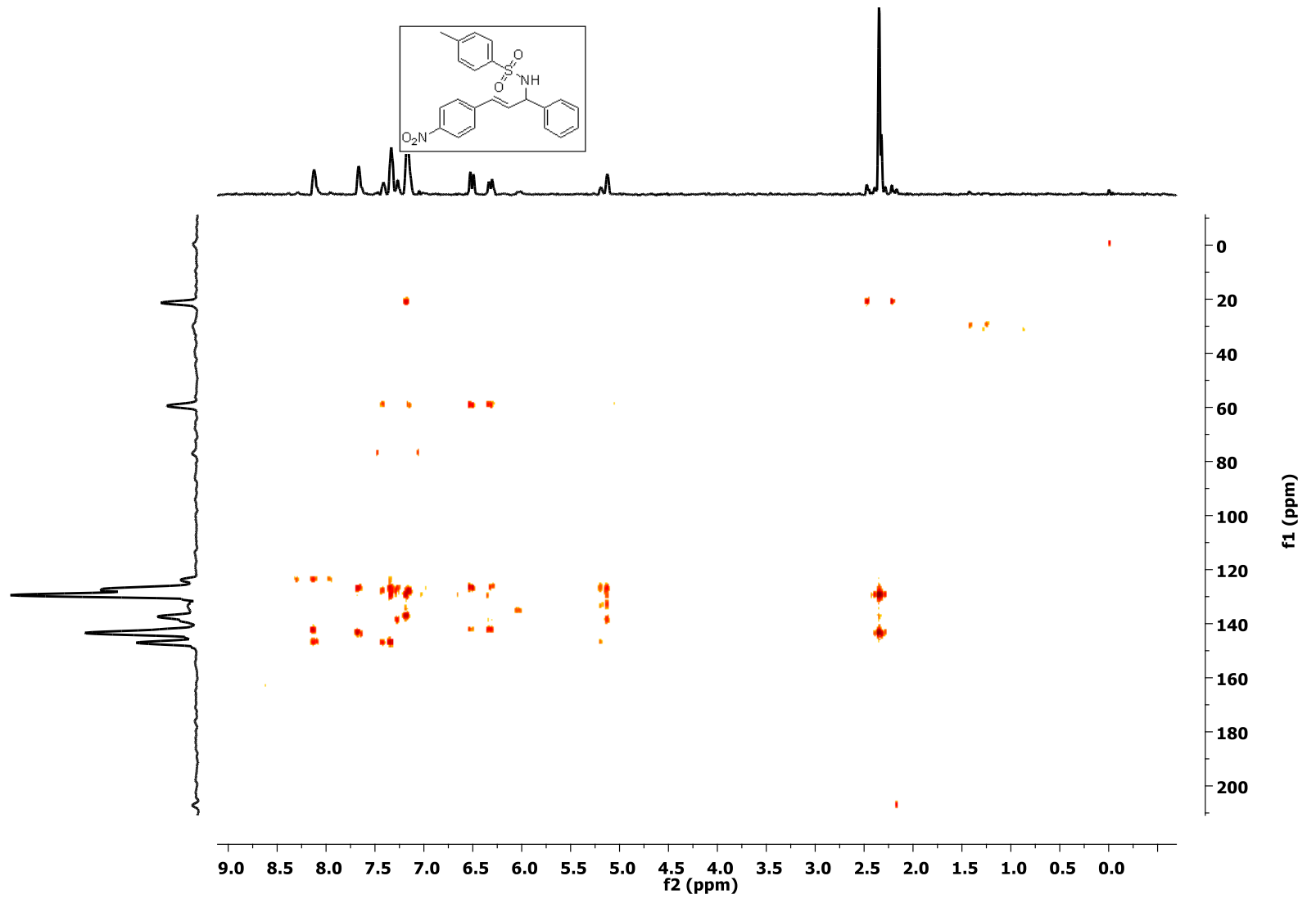




\section{${ }^{1} \mathrm{H}$ and ${ }^{13} \mathrm{C}$ spectra of compound $3 \mathrm{ma}$ and $3 \mathrm{ma}$ ':}
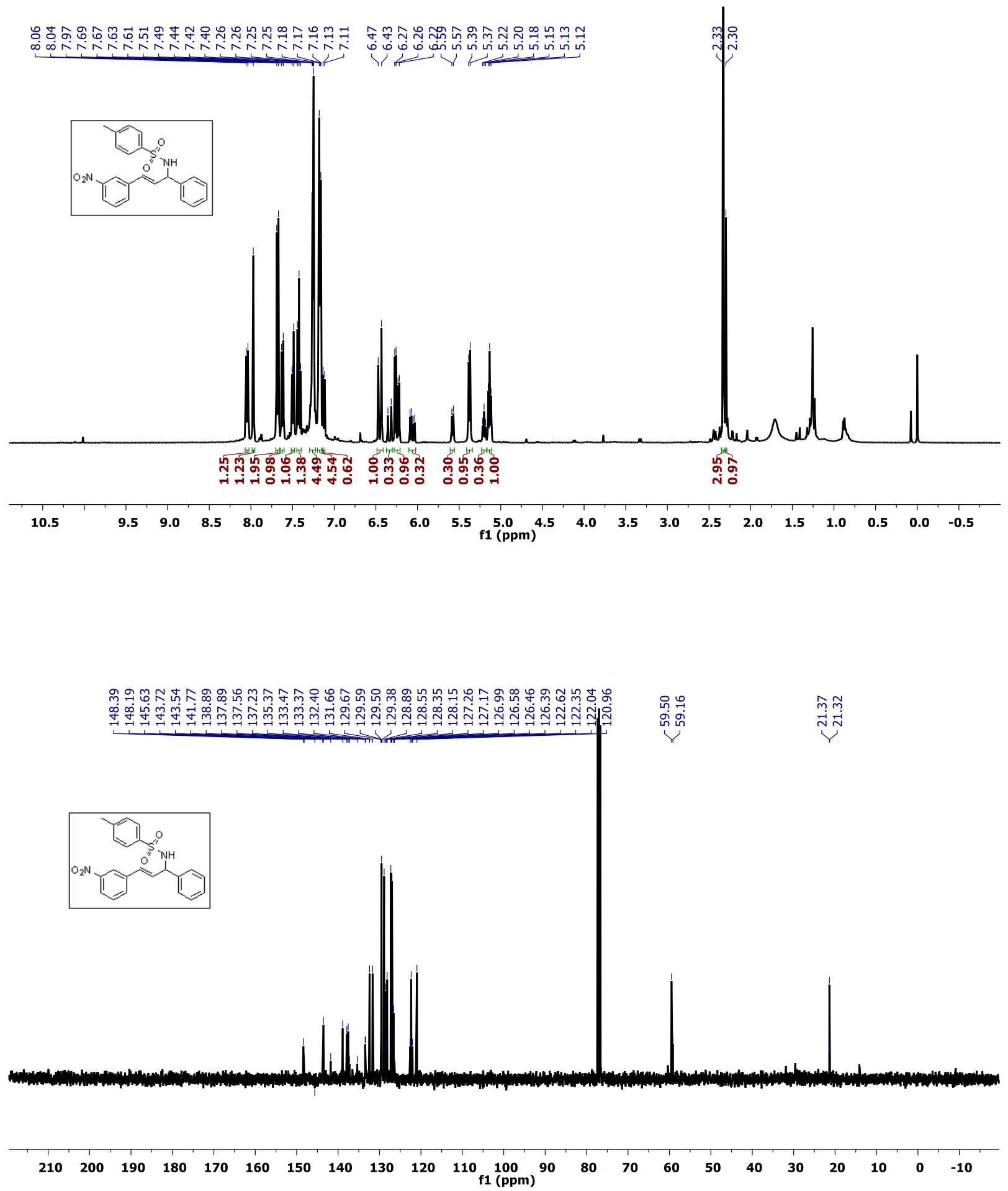
DEPT spectra of compound 3ma and 3ma':

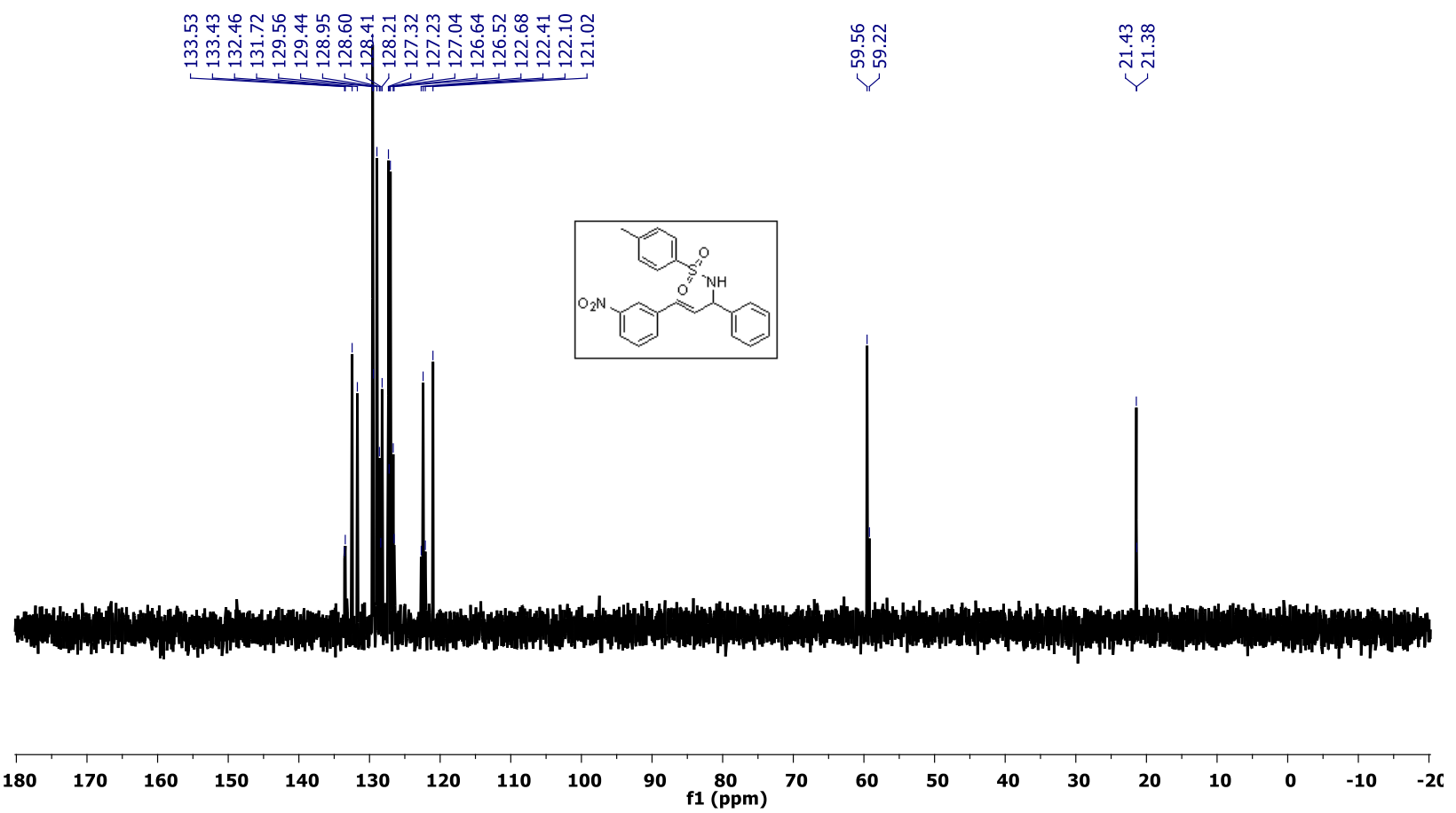


COSY NMR of compound 3ma and 3ma': In case of compound 3ma Deshielded alkene proton $\mathrm{H}_{\mathrm{a}}$ is showing a correlation with proton $\mathrm{H}_{\mathrm{b}}(6.46$ with 6.23 and 6.46 with 6.26). similarly in regioisoner 3ma' there is correlation between shielded proton $\mathrm{H}_{\mathrm{a}^{\prime}}$ with $\mathrm{H}_{\mathrm{b}}$, (6.32 with 6.04 and 6.35 with 6.07).<smiles>NC(/C=C/c1cccc([N+](=O)[O-])c1)c1ccccc1</smiles>

$3 \mathrm{ma}$<smiles>O=[N+]([O-])c1cccc(C(/C=C/c2ccccc2)N=S)c1</smiles>

$3 \mathrm{ma}$

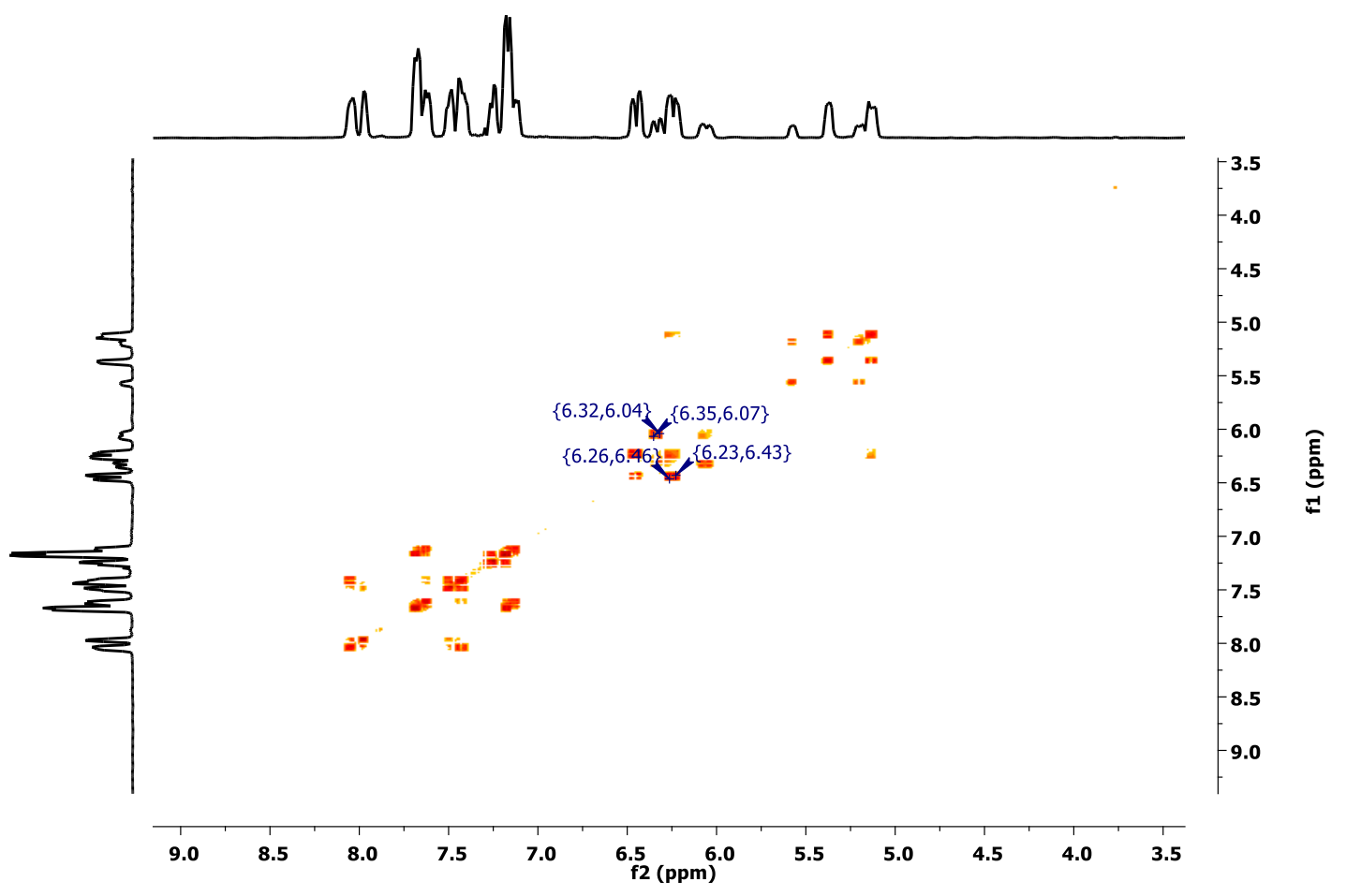


${ }^{1} \mathrm{H}$ and ${ }^{13} \mathrm{C}$ spectra of compound 3na and 3na':
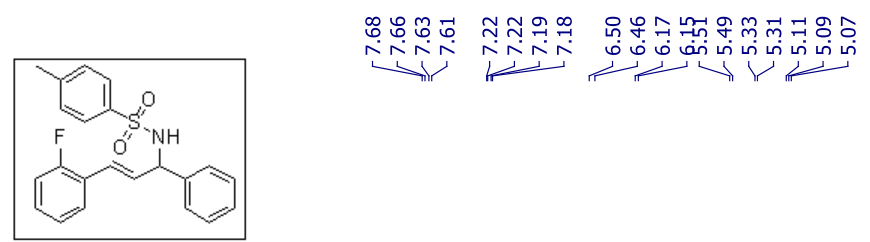

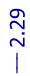
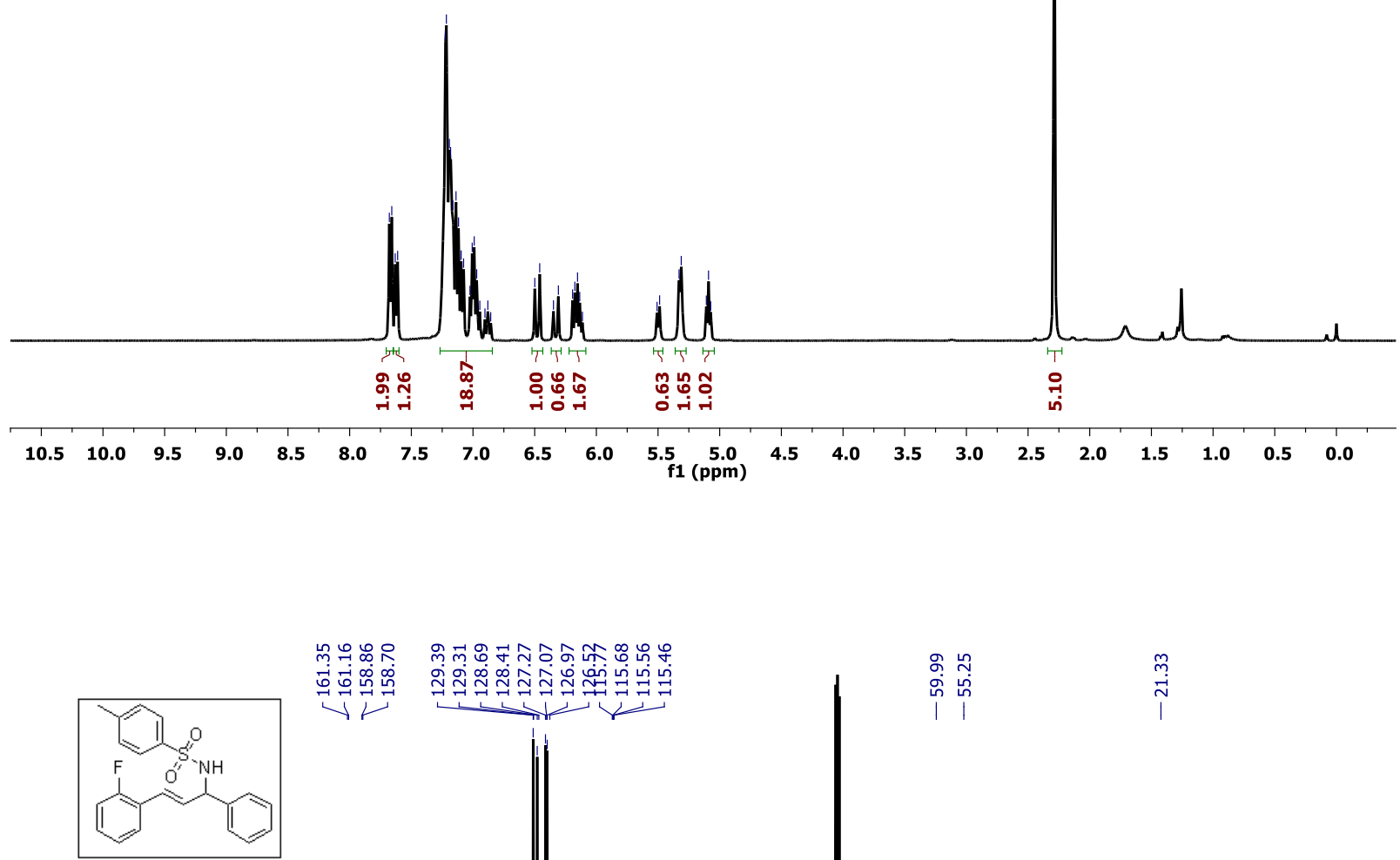
DEPT spectra of compound 3na and 3na':

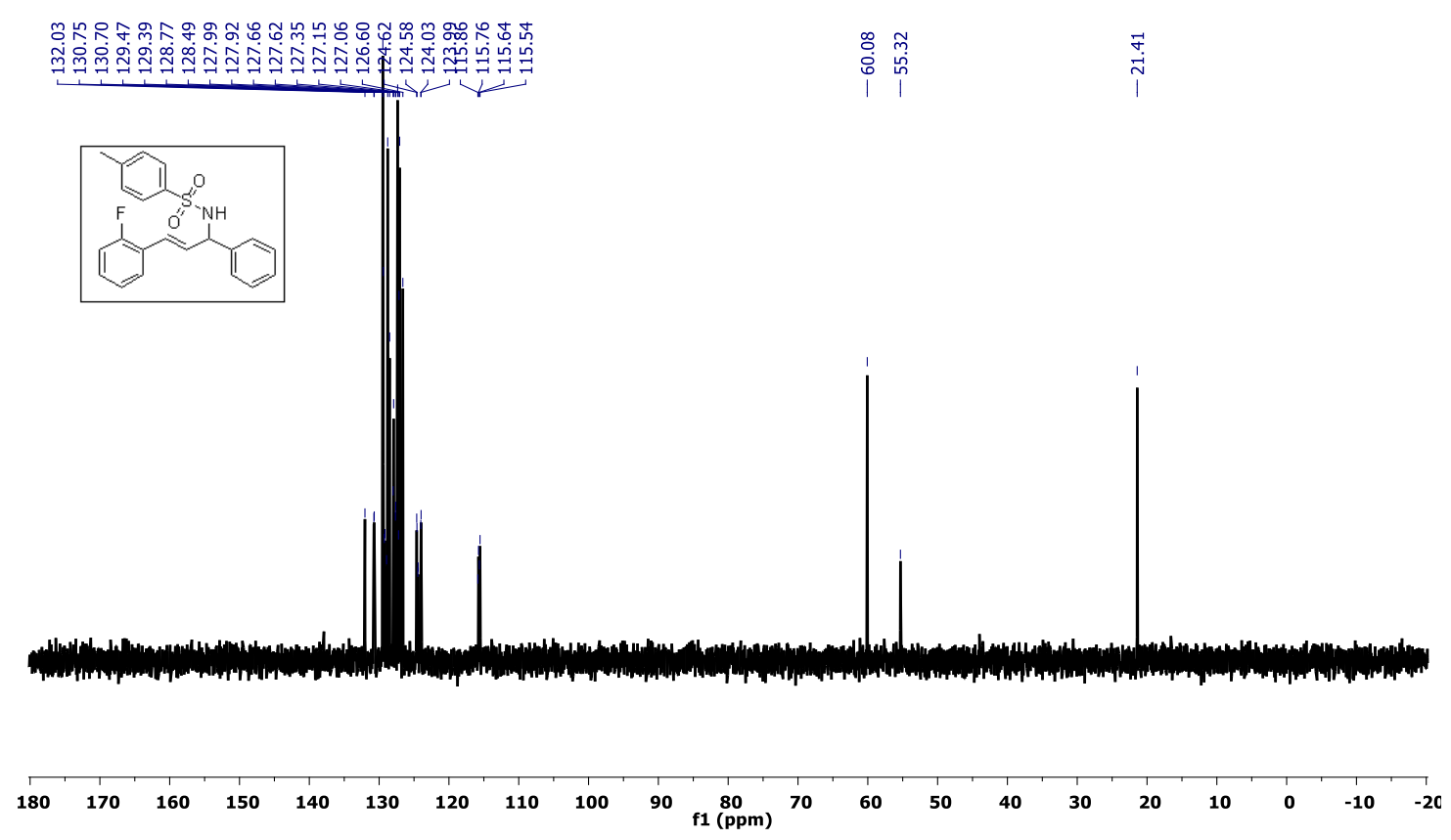

${ }^{19}$ F spectra of compound 3na and 3na':
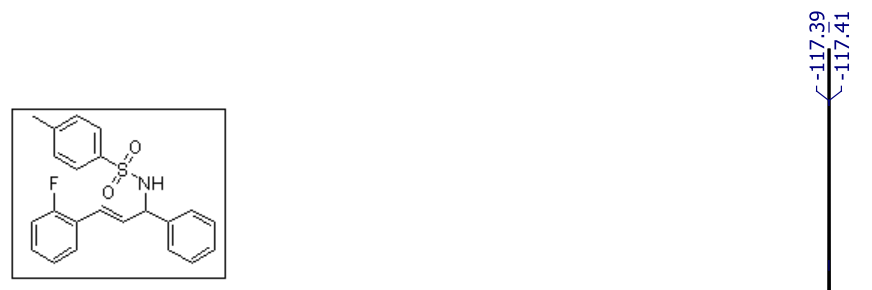

중

\begin{tabular}{|c|c|c|c|c|c|c|c|c|c|c|c|c|c|c|c|c|c|}
\hline 20 & 10 & 0 & -10 & -20 & -30 & -40 & -50 & -60 & -70 & -80 & -90 & )$^{-110}$ & -130 & -150 & -170 & -190 & -210 \\
\hline
\end{tabular}


COSY NMR of 3na and 3na':
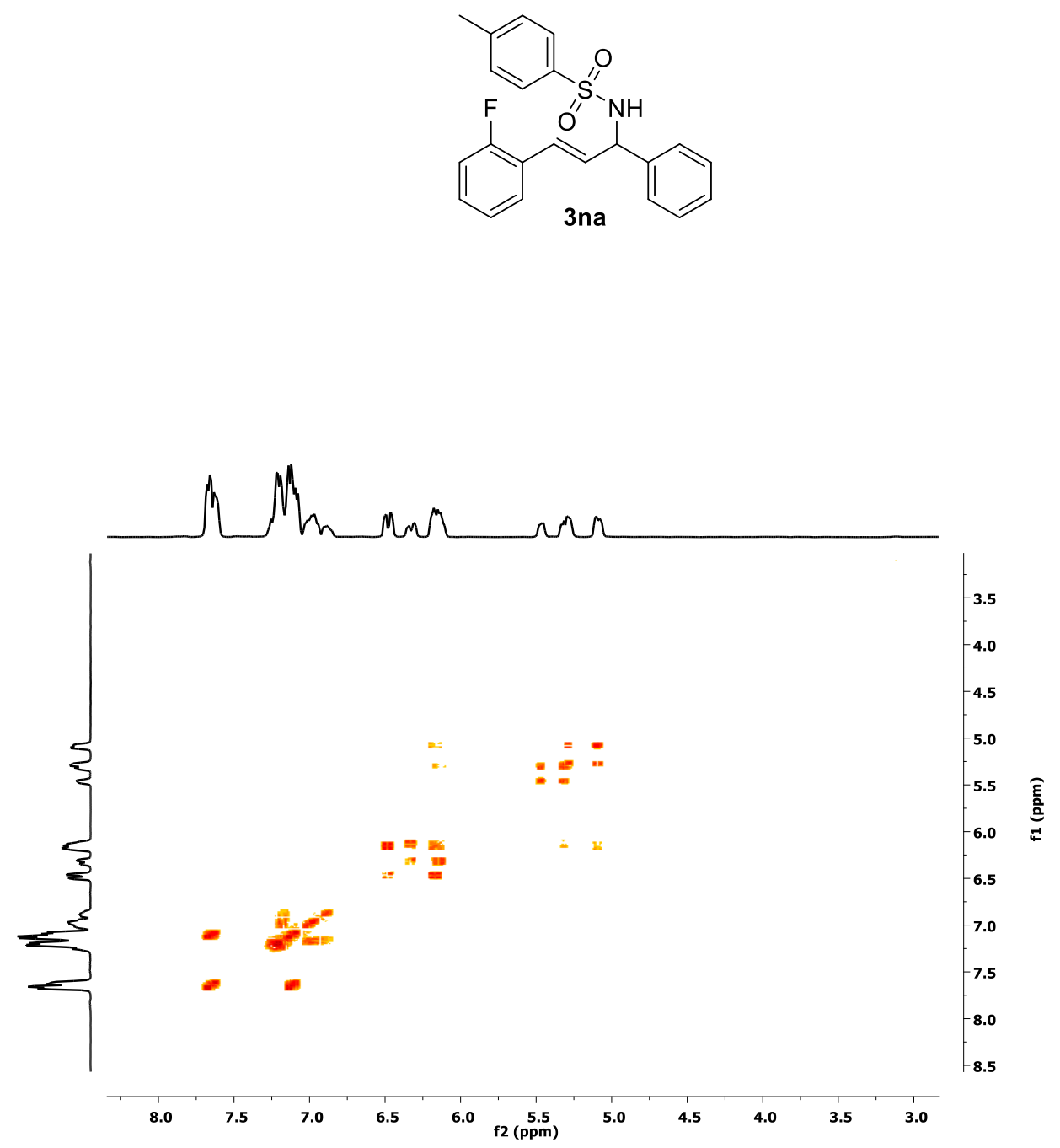


\section{${ }^{1} \mathrm{H}$ and ${ }^{13} \mathrm{C}$ spectra of compound 3oa and 3oa':}
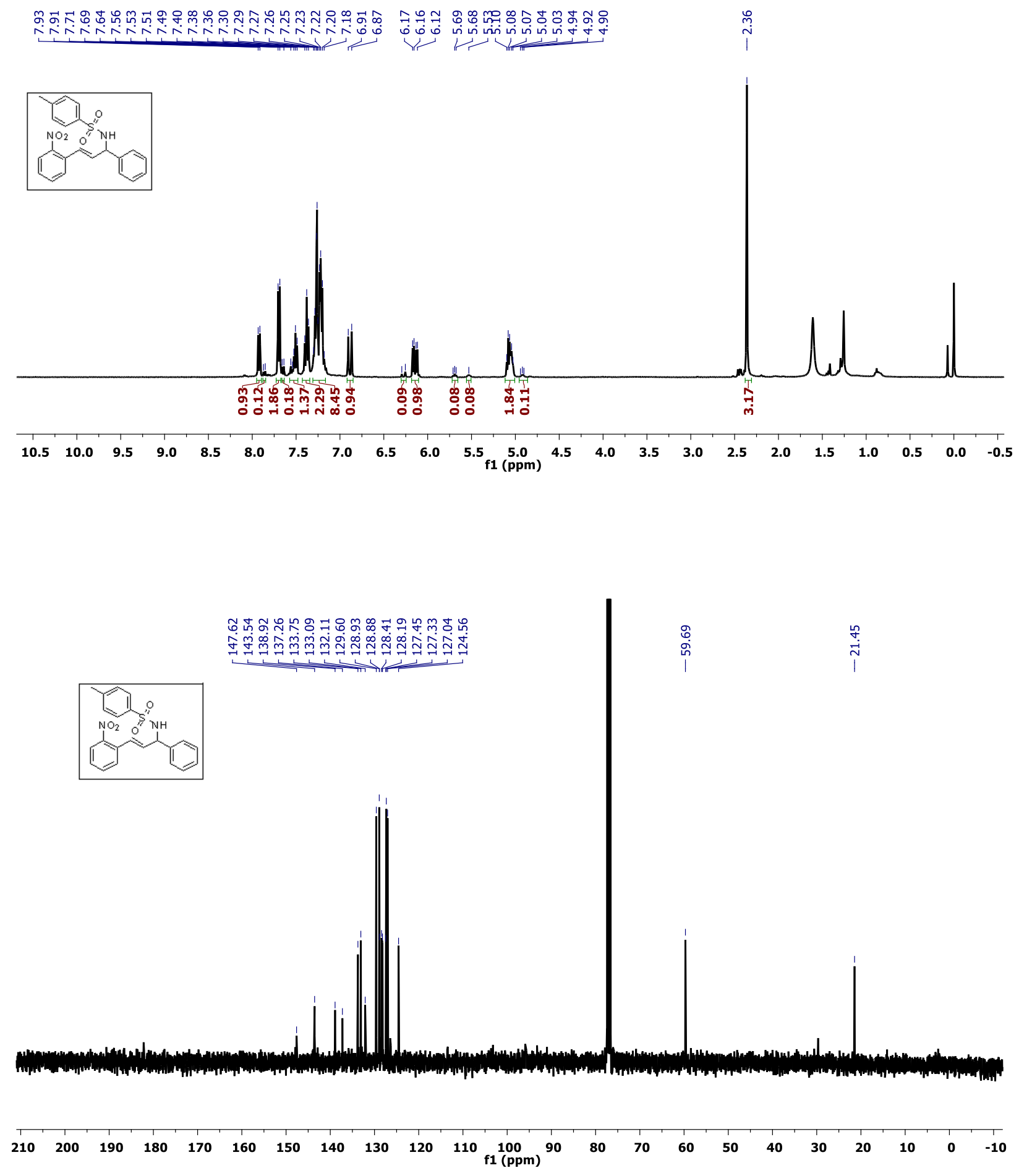
DEPT spectra of compound 3na and 3oa':
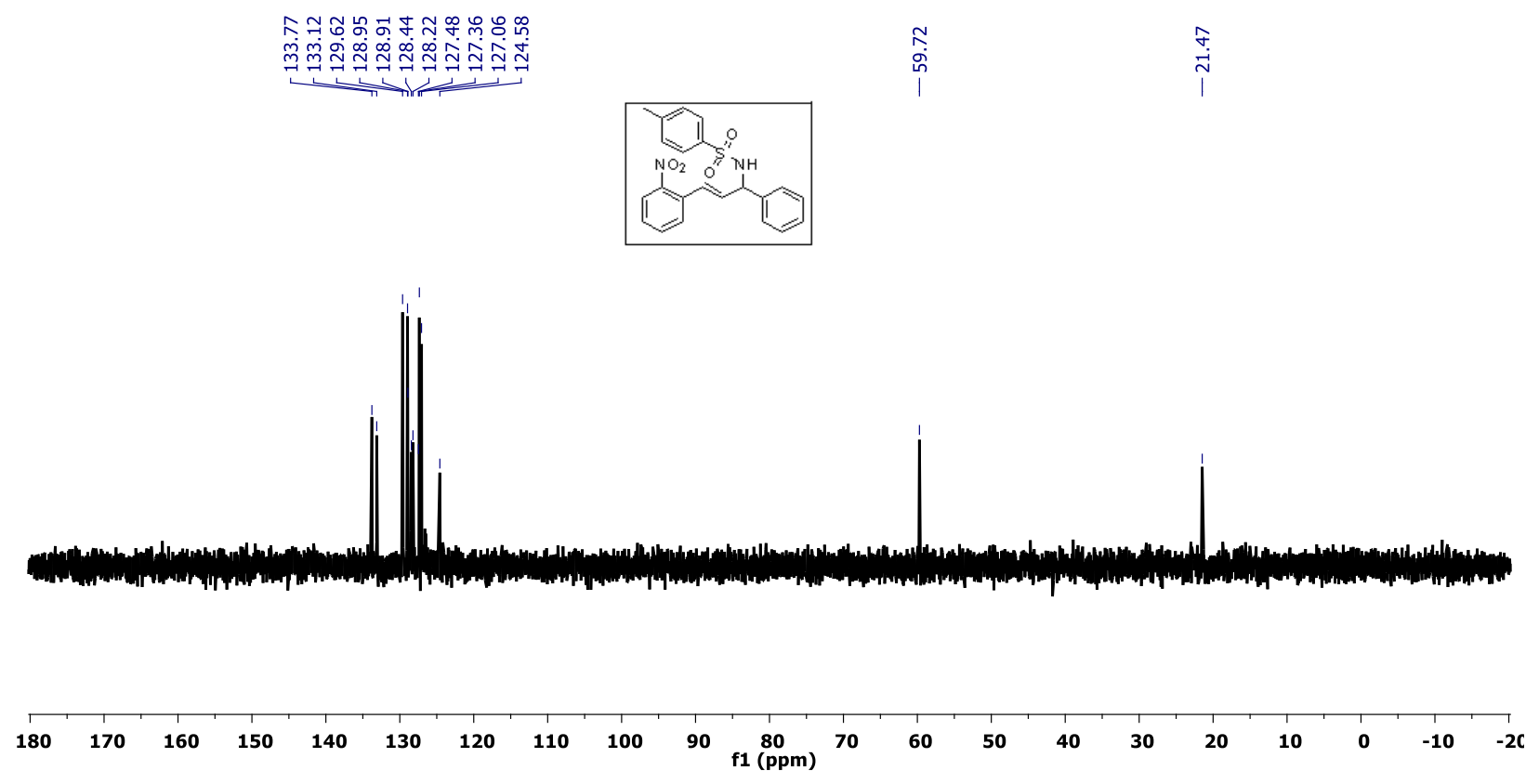
COSY NMR of compound 3oa: In case of compound 3oa Deshielded alkene proton $\mathrm{H}_{\mathrm{a}}$ is showing a correlation with proton $\mathrm{H}_{\mathrm{b}}(6.87$ with 6.16 and 6.13 with 6.90$)$.
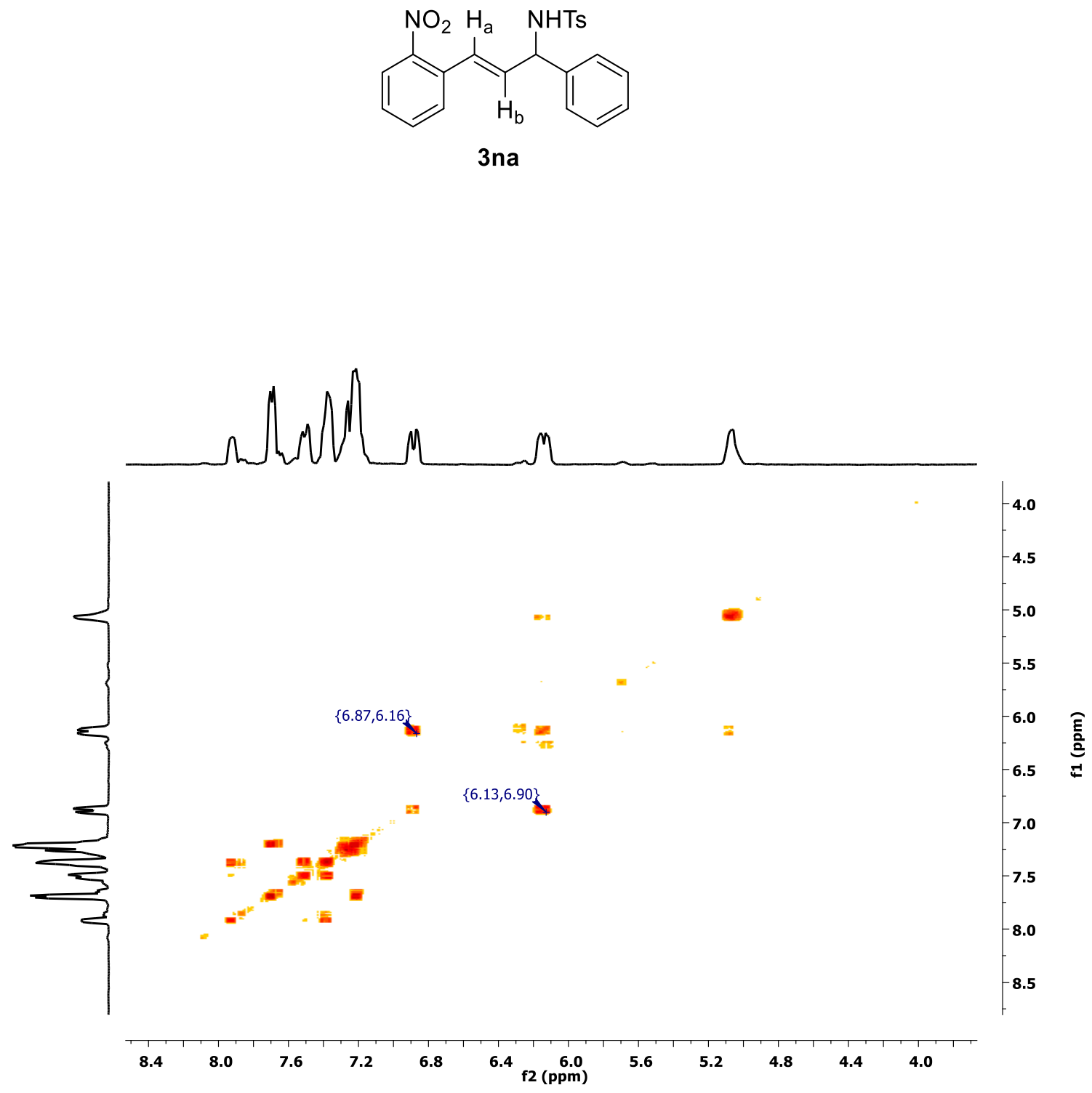
${ }^{1} \mathrm{H}$ and ${ }^{13} \mathrm{C}$ spectra of compound 3 pa:
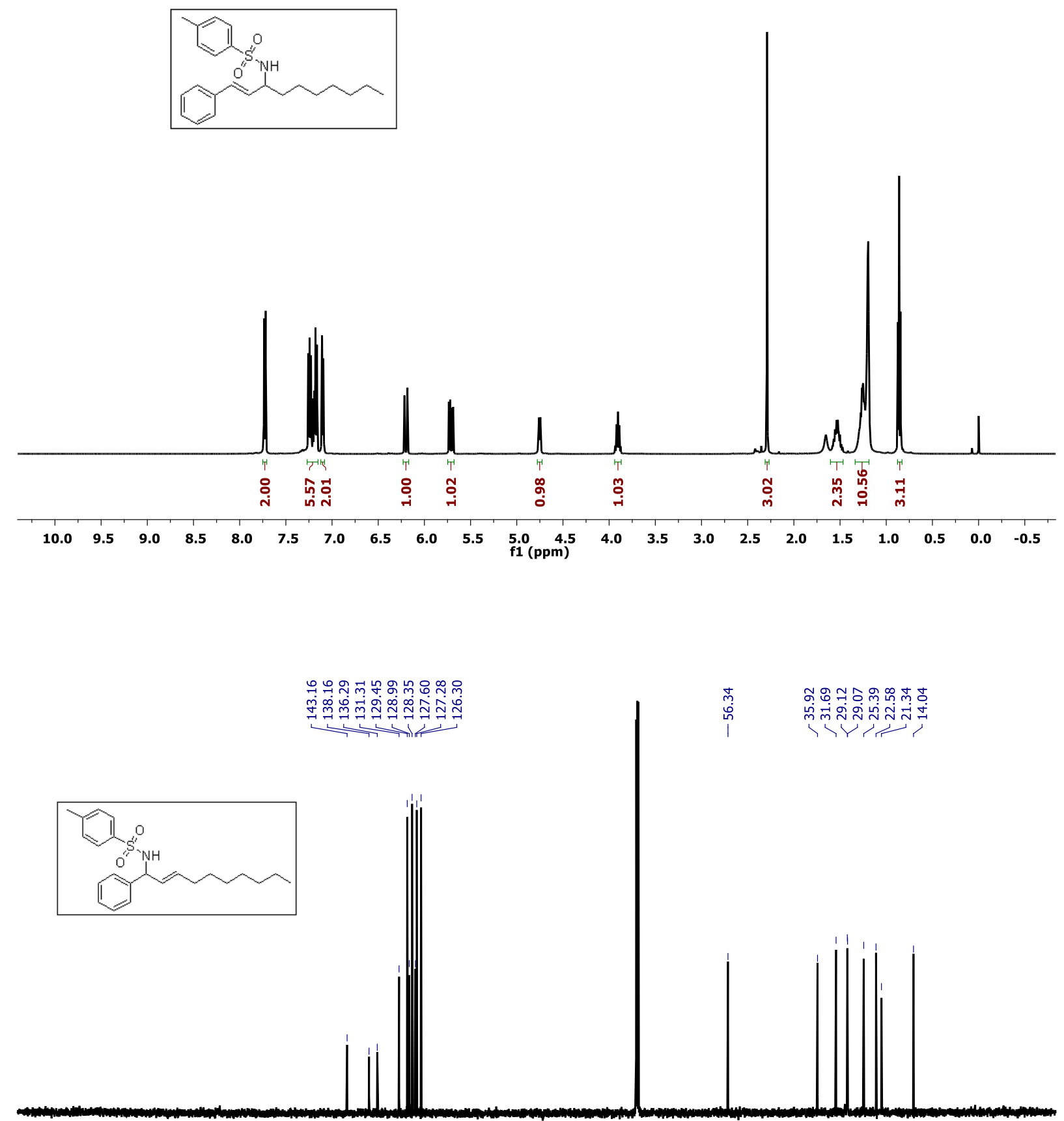

$\begin{array}{llllllllllllllllllllllll}210 & 200 & 190 & 180 & 170 & 160 & 150 & 140 & 130 & 120 & 110 & \underset{f 1}{100}(\mathrm{ppm}) & 90 & 80 & 70 & 60 & 50 & 40 & 30 & 20 & 10 & 0 & -10\end{array}$ 
DEPT spectra of compound 3pa:

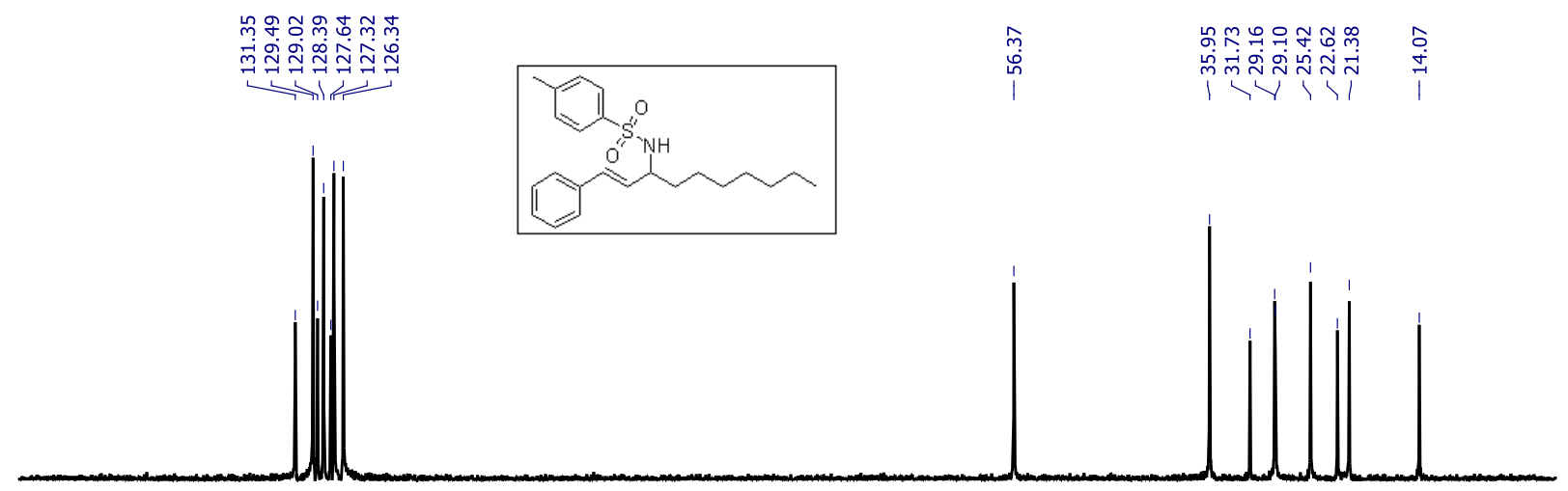

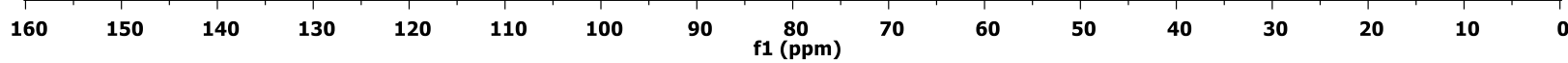




\section{${ }^{1} \mathrm{H}$ and ${ }^{13} \mathrm{C}$ spectra of compound 3qa:}
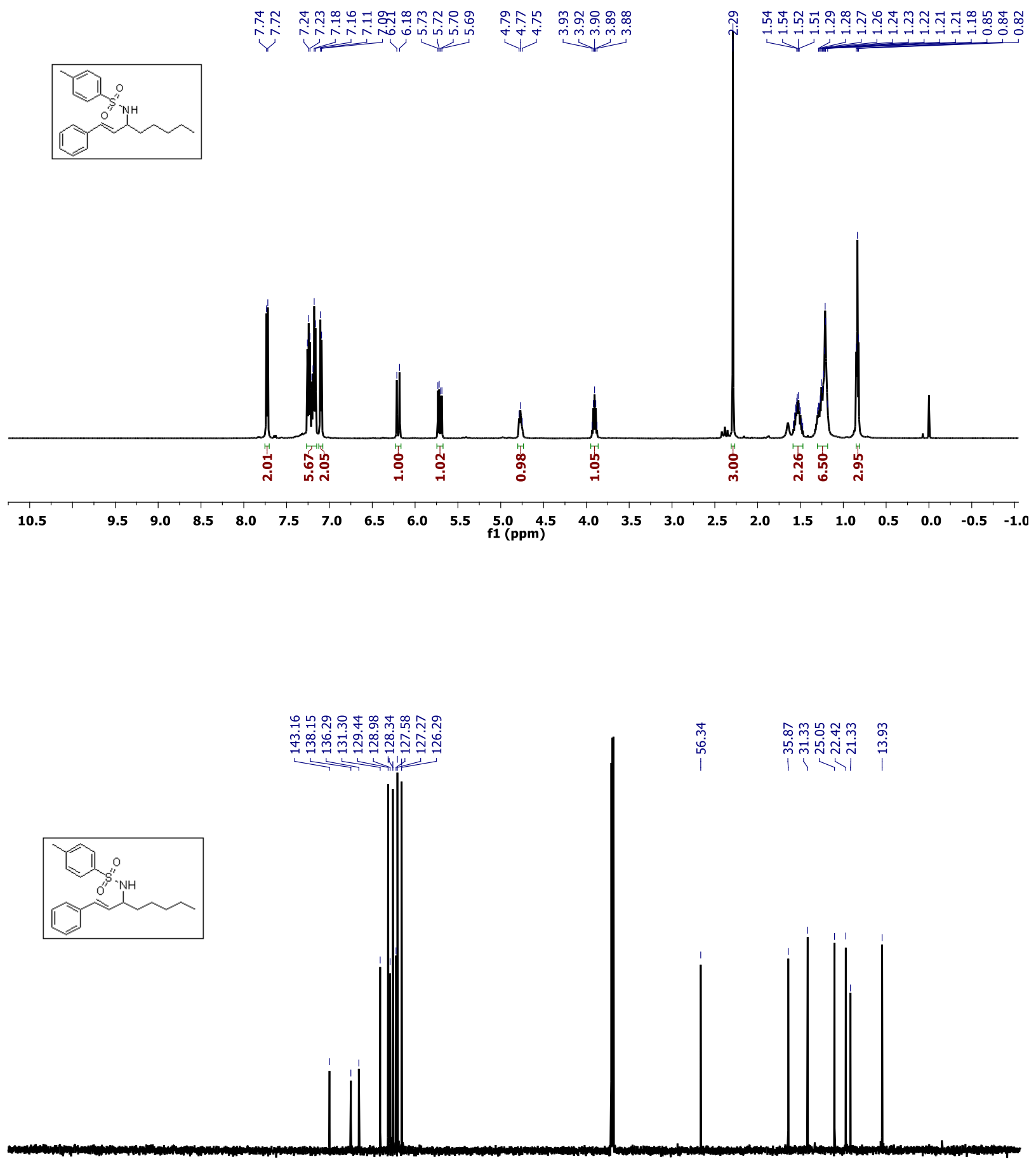

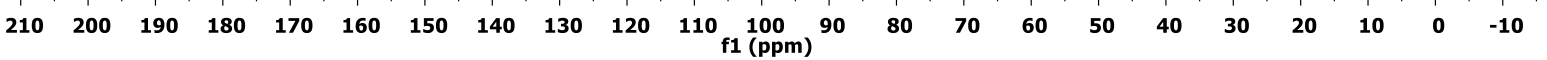


DEPT spectra of compound 3qa:

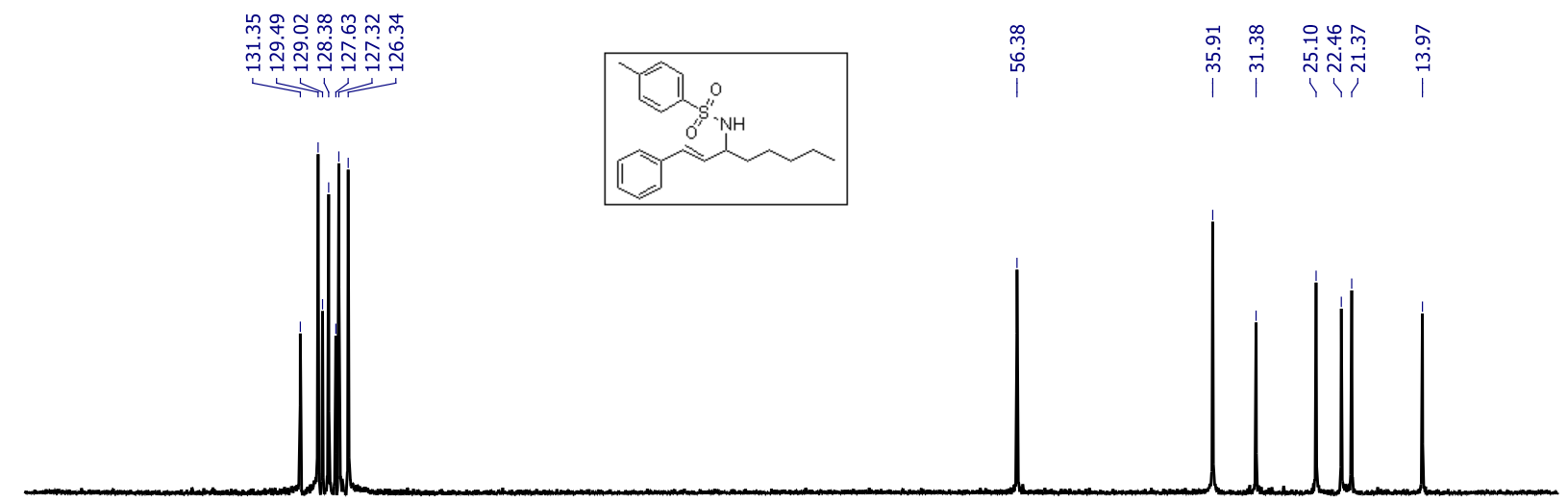

160

$150 \quad 140$

140

$130 \quad 120$

110100

90

80
1

70

50

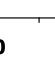


${ }^{1} \mathrm{H}$ and ${ }^{13} \mathrm{C}$ spectra of compound 3ra:
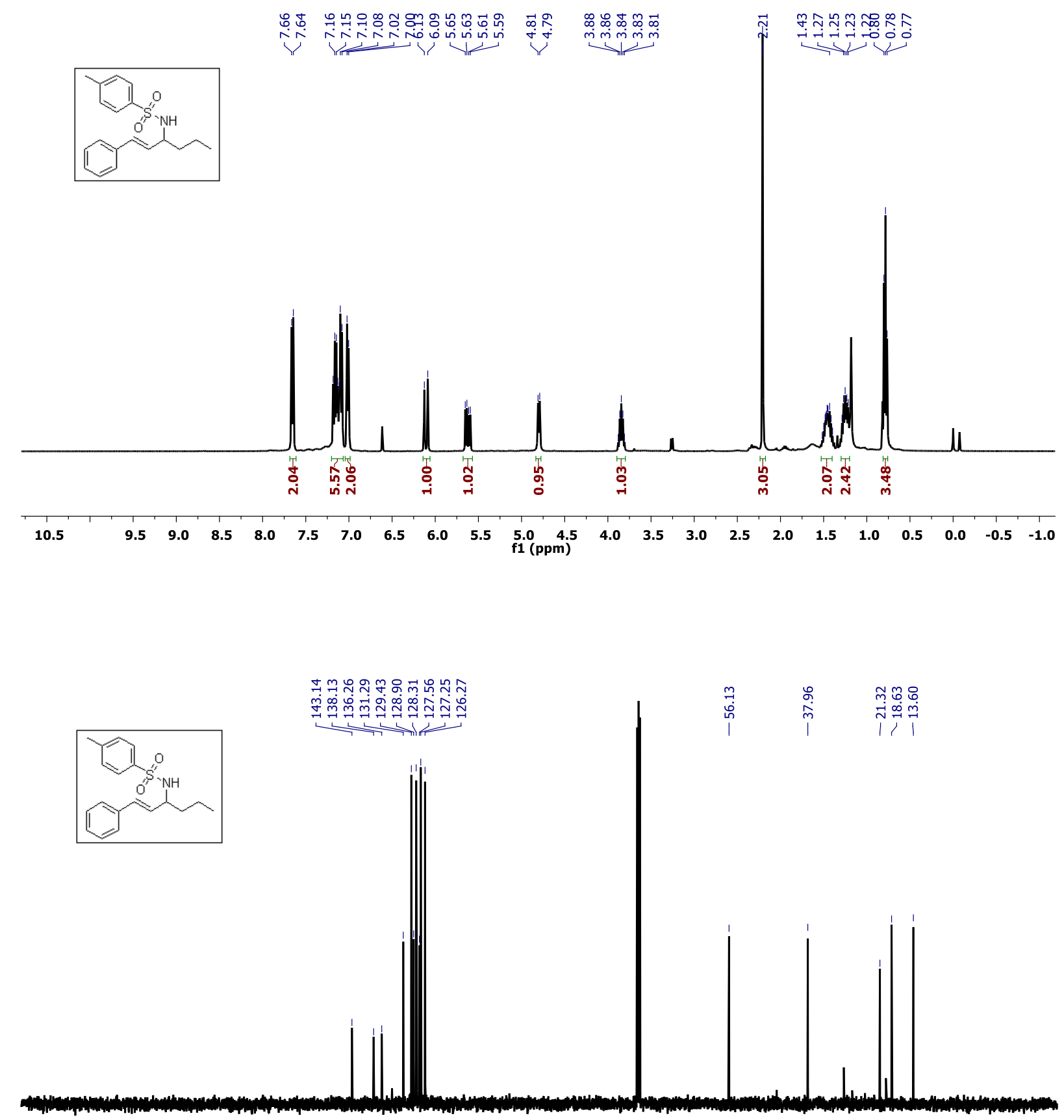

$\begin{array}{llllllllllllllllllllllllllllllll}210 & 200 & 190 & 180 & 170 & 160 & 150 & 140 & 130 & 120 & 110 & 100 & 100 & 80 & 70 & 60 & 50 & 40 & 30 & 20 & 10 & 0 & -10\end{array}$ 
DEPT spectra of compound 3ra:

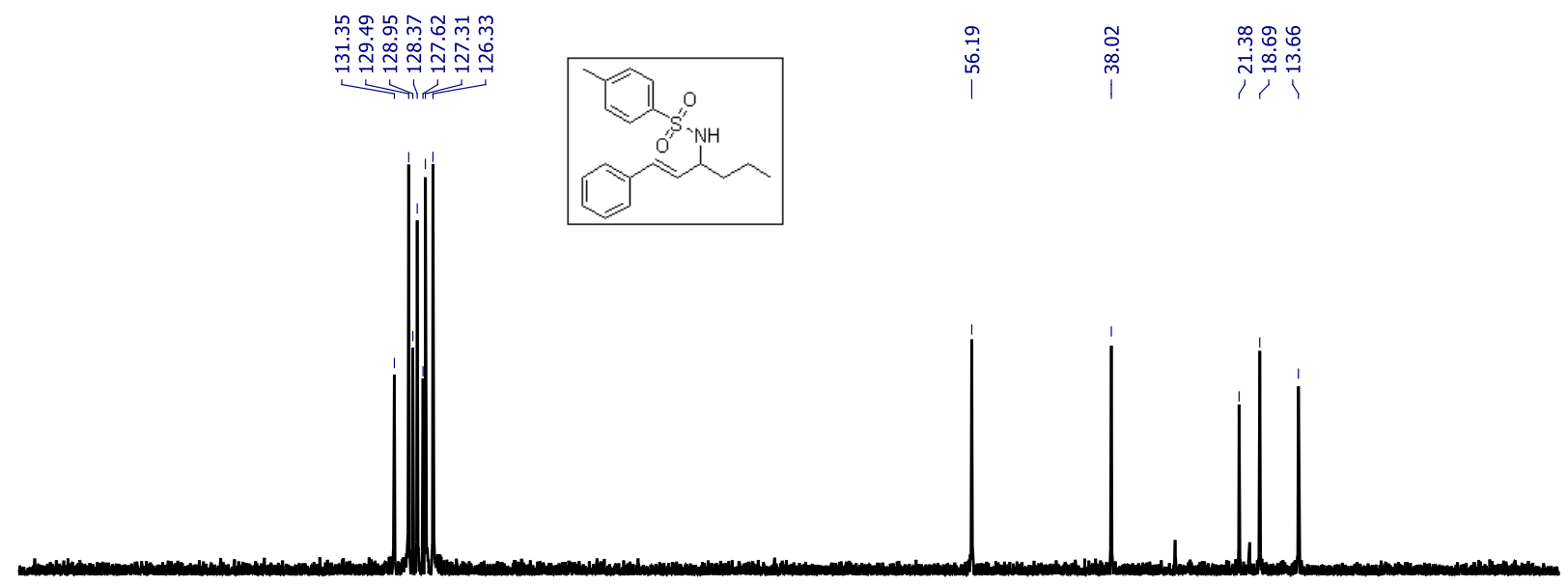

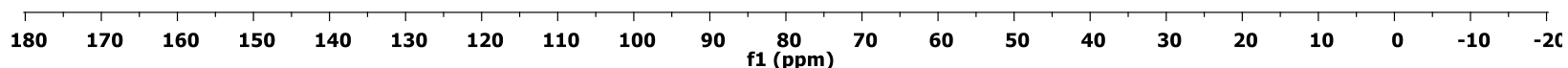


${ }^{1} \mathrm{H}$ and ${ }^{13} \mathrm{C}$ spectra of compound 3sa:
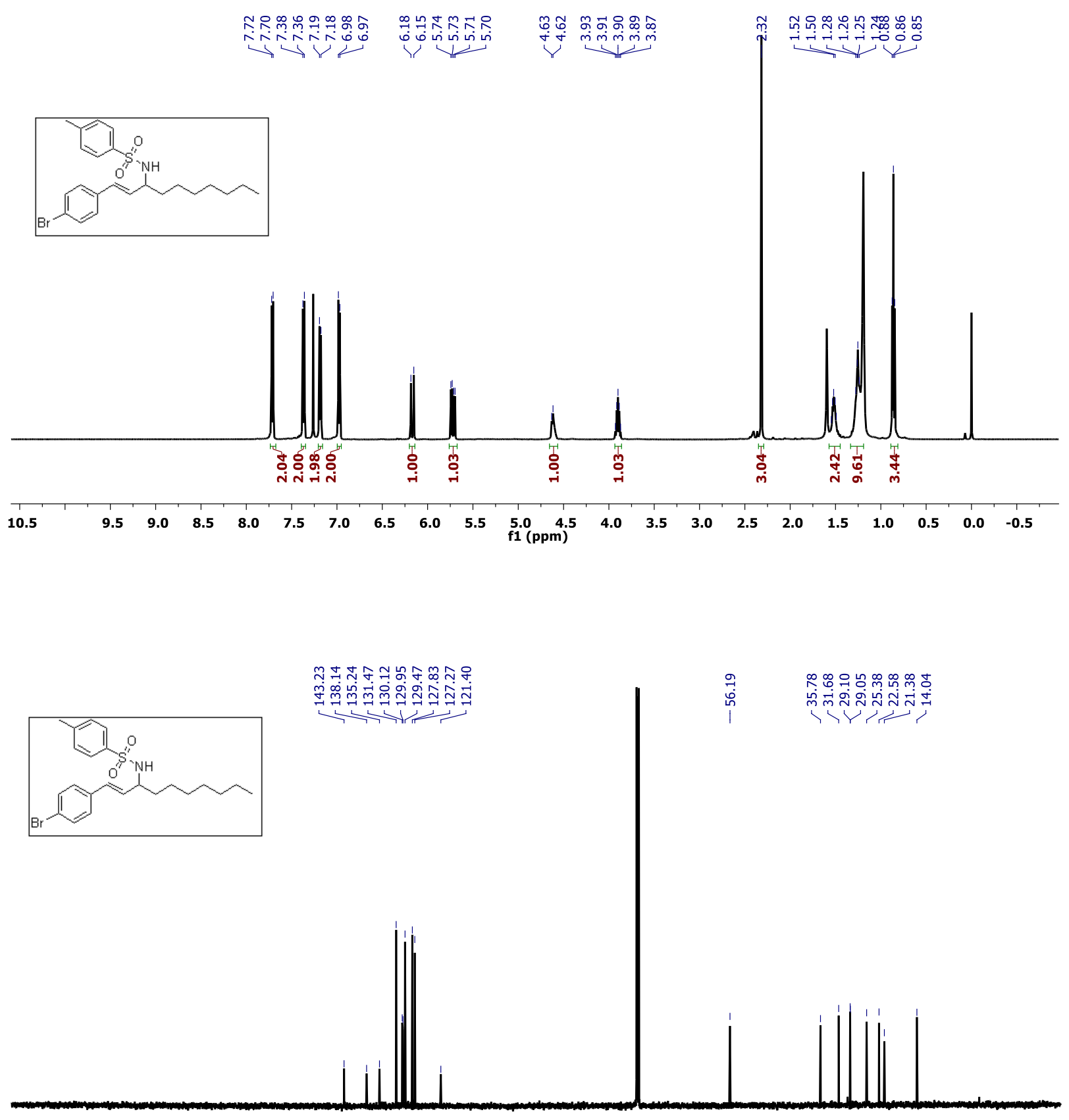

$\begin{array}{lllllllllllllllllllllllllllllllll}210 & 200 & 190 & 180 & 170 & 160 & 150 & 140 & 130 & 120 & 110 & \underset{f 1}{100}(\mathrm{ppm}) & 90 & 80 & 70 & 60 & 50 & 40 & 30 & 20 & 10 & 0 & -10\end{array}$ 
DEPT spectra of compound 3qa:

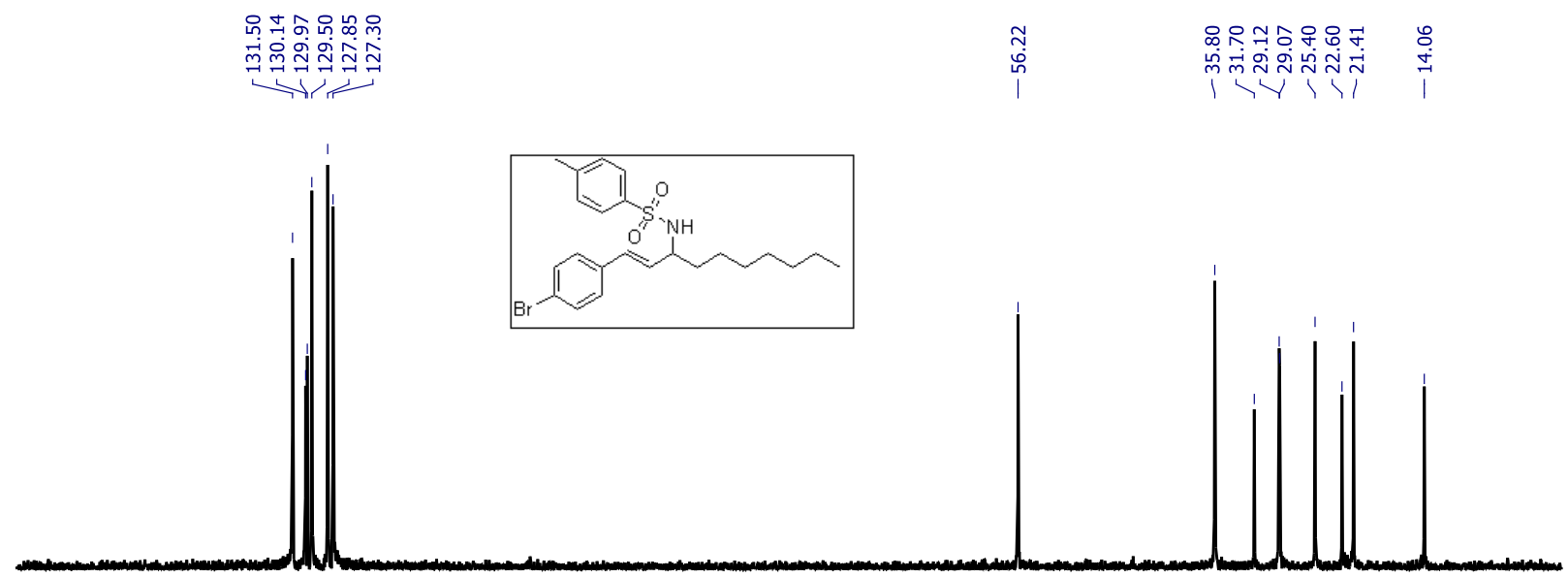

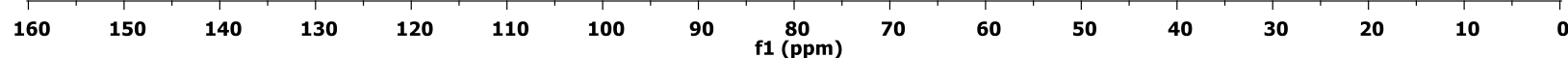




\section{${ }^{1} \mathrm{H}$ and ${ }^{13} \mathrm{C}$ spectra of compound 3 ta:}
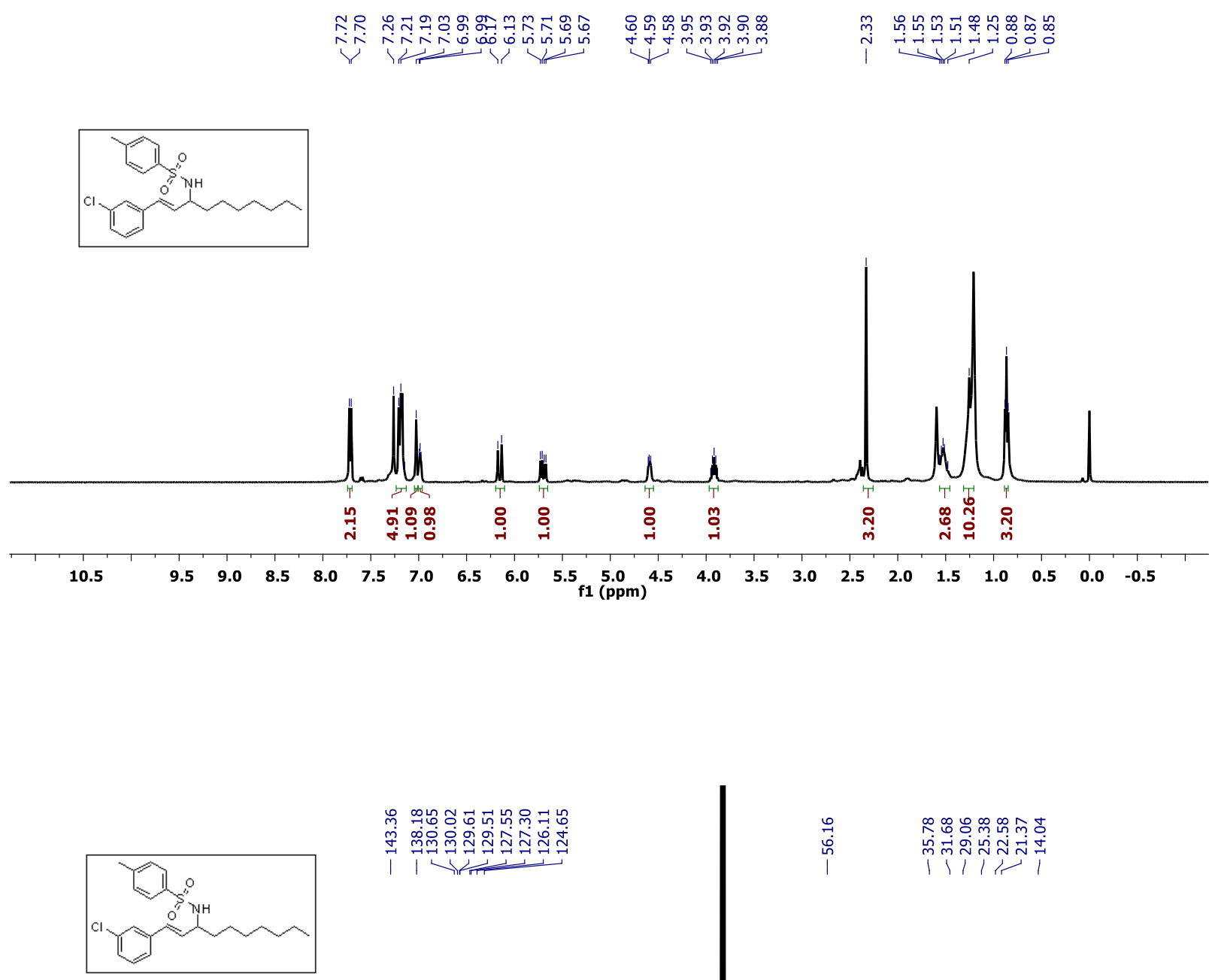

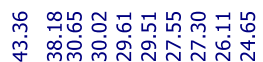

守

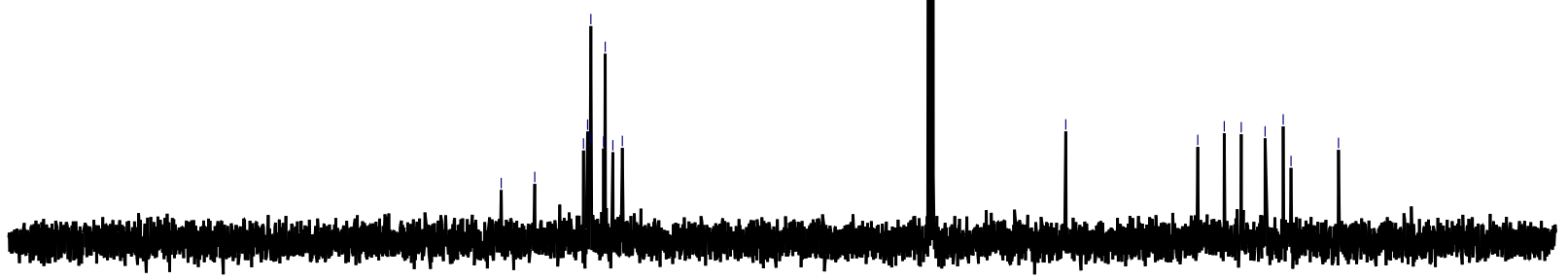

$\begin{array}{lllllll}210 & 200 & 190 & 180 & 170 & 160 & 150\end{array}$

14013

120

$110 \stackrel{100}{100}$

807

60

50

30

20

$10 \quad 0 \quad-10$ 
DEPT spectra of compound 3ta:

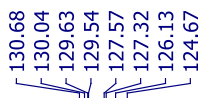

|
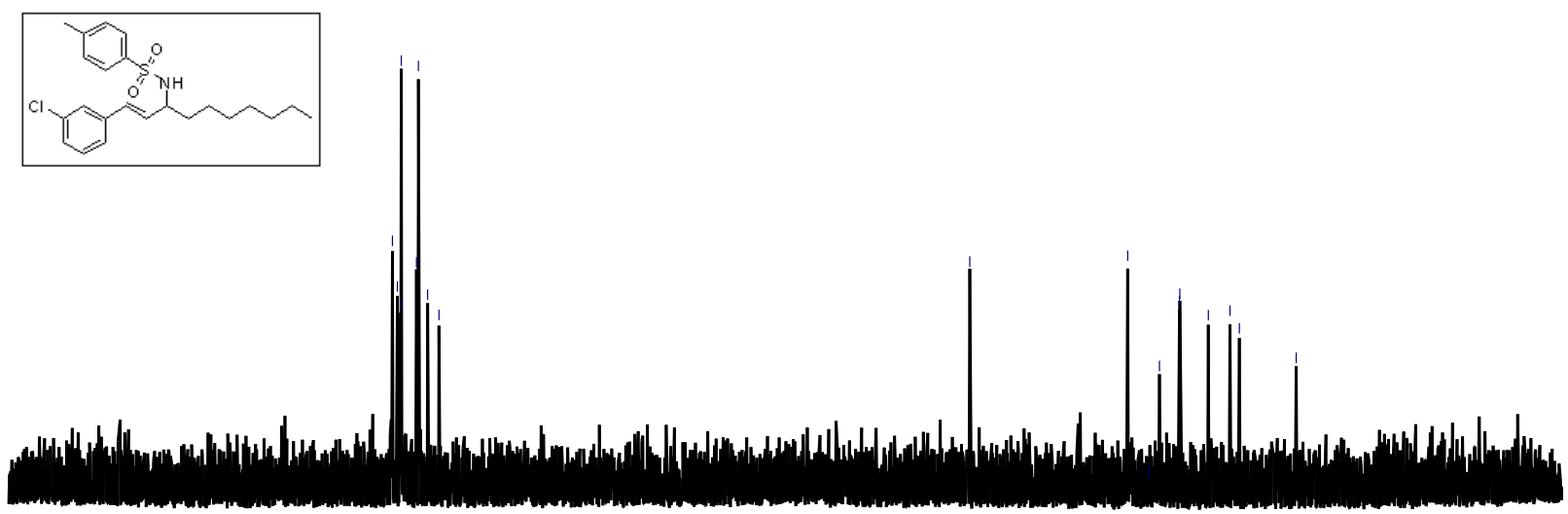

$\begin{array}{lllllllllllllllllllll}180 & 170 & 160 & 150 & 140 & 130 & 120 & 110 & 100 & 90 & \begin{array}{c}80 \\ \text { (ppm) }\end{array} & 70 & 60 & 50 & 40 & 30 & 20 & 10 & 0 & -10 & -2 C\end{array}$ 